Portland State University

PDXScholar

$1-1-2003$

\title{
The Courts and the Making of a Chinese Immigrant Community in Portland, Oregon, 1850-1910
}

Sarah Marie Griffith

Portland State University

Follow this and additional works at: https://pdxscholar.library.pdx.edu/open_access_etds

Part of the Social History Commons, and the United States History Commons Let us know how access to this document benefits you.

\section{Recommended Citation}

Griffith, Sarah Marie, "The Courts and the Making of a Chinese Immigrant Community in Portland, Oregon, 1850-1910" (2003). Dissertations and Theses. Paper 76.

https://doi.org/10.15760/etd.76

This Thesis is brought to you for free and open access. It has been accepted for inclusion in Dissertations and Theses by an authorized administrator of PDXScholar. Please contact us if we can make this document more accessible: pdxscholar@pdx.edu. 


\begin{abstract}
An abstract of the thesis of Sarah Marie Griffith for the Master of Arts in History presented November 22, 2002.
\end{abstract}

Title: The Courts and the Making of a Chinese Immigrant Community in Portland, Oregon, 1850-1910.

This thesis studies the development of the Portland, Oregon Chinese immigrant community between 1850 and 1910. Chinese immigrants first arrived in Portland in the mid-1850s and quickly created businesses as well as social institutions they transplanted from China to the U.S. West. They also established intricate relationships among themselves and with members of the surrounding white community. County and state court records held at the Multnomah County Courthouse and National Archives in Seattle, Washington, reveal much about the Chinese immigrant community in Portland and provide a window into a society that left few written records.

Through the analysis of hundreds of court cases held at the Multnomah County Courthouse in Portland, this thesis reconstructs four broad aspects of Portland's Chinese immigrant community. The first chapter discusses the arrival and establishment of Chinese immigrants in Portland. The second chapter discusses Chinese experience with white missionaries in the courts as both groups battled for 
custody rights to Chinese women and children. The third chapter looks at the case of United States v. John Wilson, which revealed how Chinese and whites had collaborated to establish one of the largest and most successful immigrant and opium smuggling rings on the West Coast. With the aim of profiting from Chinese exclusion, the white and Chinese operators of this ring bridged racial barriers that had, for decades, divided the two groups. In chapter four, finally, the thesis examines social conflict within the late nineteenth century Portland Chinese community. This chapter describes how internal conflicts in Portland Chinatown, stemming from traditional social associations transplanted from China, played as strong a role in shaping the Chinese community in Portland as did exclusion laws determined to end the entry of Chinese to the United States. 
THE COURTS AND THE MAKING OF A CHINESE

IMMIGRANT COMMUNITY IN PORTLAND,

OREGON, $1850-1910$

by

SARAH MARIE GRIFFITH

A thesis submitted in partial fulfillment of the requirements for the degree of

\author{
MASTER OF ARTS \\ in \\ HISTORY
}

Portland State University

2003 
For My Parents

Kathryn Griffith and John Griffith 


\section{CONTENTS}

List of Tables

Introduction 1

Chapter One 9

A New Hierarchy: Tradition, Adaptation, and Agitation in Portland's Chinatown

Chapter Two

A Division Between: Missionary Influence and Conflict in Portland's Chinese Enclave, 1879-1900

Chapter Three

Border Crossings: Race and Illegal Immigration in Portland and British Columbia

Chapter Four

98

Chinese Associations in Portland: Unity and Division within Adapted Social Institutions

Conclusion

Bibliography 


\section{LIST OF TABLES}

Table 1: The cipher code used by white and Chinese smugglers

to transport opium from British Columbia to Portland aboard

the Haytian Republic and Wilmington 


\section{Introduction}

In the late 1850s, Chinese immigrants first arrived in Portland, Oregon. As their community grew, Portland Chinese found themselves at odds with their own countrymen as well as the surrounding white community. This thesis discusses the development, growth, and challenges faced by Portland's first-generation Chinese immigrants between 1860 and the turn of the century. It emphasizes the unique ways in which these people adapted to the demands, challenges, and opportunities presented in the U.S. West.

Beginning in 1848 , Chinese immigrated to the North American West to chase after gold in California. In 1858, when gold was discovered in southern Oregon, hundreds of Chinese left California for the new gold fields in the Rogue River Valley. At the same time, others migrated further north to seek opportunities in Portland, a city developing at the confluence of the Columbia and Willamette Rivers. Over the next four decades, a bustling, thriving Chinatown developed in the river city. A Chinese merchant class quickly grew up alongside a range of immigrant institutions, with merchant Chinese as these institutions' financial and organizational leaders. The community's infrastructure continued to develop in the years prior to the national Chinese Exclusion Act of 1882, which, through its discriminatory provisions, shaped Chinese American lives dramatically until the act's revocation in 1942. While nineteenth century whites viewed Chinese immigrants as a homogenous entitysharing culture, customs, and experience-in reality a distinct class culture developed 
in Portland's Chinatown, with common laborers, middle-level merchants, and elite Chinese merchants each fitting into a larger whole.

Although Portland's nineteenth-century Chinese population eventually numbered in the many thousands, it did not leave the range of records that historians have used to reconstruct other Chinese communities along the Pacific Coast. For instance, Portland Chinese did not print Chinese-language newspapers nor did they leave behind many letters, much less extensive collections of correspondence or other written documents about the early years of Chinese immigration or about the texture of immigrant social life.

To understand the development of Portland's Chinatown, then, it is necessary to delve into primary sources which are often overlooked and that document these immigrants' experiences. In this thesis, I have used court records from the county, circuit, and district courts, alongside English-language newspapers and the writings of white observers, to reconstruct the daily lives of Chinese. The thousands of court records, in particular, provide a wide array of details about the business and social aspects of Portland's early Chinese community. They testify also to the unique challenges and adaptations first-generation Chinese immigrants experienced in Portland and how these experiences shaped the way Chinese interacted with one another and with the majority white population. Finally, and perhaps most vital to Chinese immigrant studies, court records show that, contrary to the traditional historic record, not only did Chinese appear in the U.S. courts to plead cases against one another and against whites, they did so constantly, in both civil and criminal trials that 
challenged the court to acknowledge their presence and claims to justice-even in the absence of citizenship. ${ }^{\prime}$

Court records from these three local and state courts between 1858 and the turn of the century demonstrate the variety of challenges faced by Chinese immigrants. They shed light on the way Chinese interacted with one another, the patterns of conflict within Chinatown, and shifts in the demography of Portland's Chinese population between 1860 and 1910. Through these records, it is clear that Chinese struggled among themselves, as often as they did with whites, in individual and group efforts to establish authority and autonomy. During the eariiest decades of Chinese exclusion, 1882-1892, the period that has received the most attention by historians, we see that Chinese continued to adapt and develop individual and community autonomy in and out of the courts, despite harsh anti-Chinese legislation that severely limited their freedom in the United States.

Chapter One introduces, through demographic analysis, Portland's Chinese population. Beginning with 1858 , it shows when and from where Chinese came and the physical geography of Portland's earliest Chinatown. As the Chinese population increased through the 1860 s, so too did the daily struggles that individuals faced. This

\footnotetext{
${ }^{1}$ While court cases that involved Chinese number in the thousands for Multnomah County, it must be remembered that court records, nonetheless, document only a portion of Chinese experiences. Specifically, the lives of those Chinese men and women who either brought cases to court or were brought to trial by individuals, the City of Portland, and the State of Oregon. To make up for this shortfall, I have tried to use a variety of primary sources that fill in gaps left in court records. These include letters from Chinese immigrants in other Chinese communities throughout Oregon, English-language newspapers, and mission reports from religious organizations that worked among Chinese in Portland.
} 
chapter surveys some of the more common challenges immigrants faced in the decades leading up to exclusion. First, the chapter shows how Chinese laborers fit into a larger labor system and how traditional institutions transplanted from China aided laborers in their struggle for fair treatment in a white-dominated economy. It also describes the establishment and growth of a powerful Chinese merchant class, which helped immigrants find work through labor contracting and at the same time mediated conflicts between Chinese laborers and their white employers. However, as the Chinese population of Portland grew, so too did pressure for immigrants to assimilate into the American mainstream. As this chapter demonstrates, with increased pressure to assimilate to Western culture in the form of dress, religion, and language, came new conflicts among Chinese. While many adopted western capitalist economics, cultural assimilation was clearly more problematic. Over the first three decades of Chinese community development, the situation turned increasingly tense, leading to bloody altercations in the streets and houses of Chinatown.

Chapter Two follows by demonstrating how Chinese were discriminated against in cases that had their roots in legal conflicts over culture and morality. The racist undertones and judicial violations of due process that pervaded these cases is in striking contrast to others, where money, trade, and even violence within the Chinese enclave were at issue. The courts accorded Chinese plaintiffs and defendants much the same treatment as it accorded whites in these latter cases.

Beginning in the 1870s, missionaries established English-language schools in Portland. Chinese laborers and merchants attended mission schools primarily to learn 
the English language. Others, however, adopted Christianity and were consequently ostracized by their fellow countrymen in the ethnic enclave. Missionary influence divided Chinese between those who subscribed to the missionary influence in Chinatown culture and those who fought the same influences in the streets and courtrooms of Multnomah County. A majority of the Chinese population resented aggressive missionary activity in Chinatown, such as street preaching, social reform programs, and mission and refuge homes. By the late 1880 s and the 1890 s, the results of these tensions appeared in the courts in the form of custody battles between Chinese immigrants and white missionaries. Missionaries, willing to accept those Chinese who converted to Western religious practices, worked against other Chinese who fought the assimilation process. Employing popular racist imagery, missionaries battled with Chinese in the courts for moral and cultural control, especially in cases that involved Chinese women and children who, missionaries believed, were at risk because of the vice they thought permeated Portland's Chinatown. Sympathetic judges and law enforcement officials reinforced these stereotypes, providing a legal mandate for the use of racist and ethnocentric images.

Chapter Three centers on a different type of conflict between whites and Chinese during the era of exclusion. The U.S. District Court case, U.S. v. Wilson (1893), which involved some 28 white and Chinese opium and immigrant smugglers, displays some of the loopholes that existed in exclusion measures and how Chinese and whites used these loopholes to profit off the misfortune of Chinese who sought entry into the United States. More importantly, U.S. v. Wilson shows how 
opportunities for illicit profit transcended the legal and cultural breach between whites and Chinese. Chinese merchants in Canada, Portland, and San Francisco aligned with one another and with whites to turn profits off exclusion era laws. The events that led up to the case, and the trial itself, reveals that a distinct class structure had developed in Portland's Chinatown by 1890 , with merchants serving as leaders among their own countrymen and as powerful dealers with white collaborators.

Finally, Chapter Four documents internal struggles within Chinatown. As Chinese arrived in the United States, they organized themselves roughly along the lines of traditional social associations, most notably clan and district associations and secret societies, or tongs. In the first decades of Portland's Chinatown, under the leadership of powerful Chinese merchants, associations localized their power, providing merchant leaders, especially, with power in the immigrant enclave. With the advent of exclusion, a number of Chinese associations took advantage of the opportunities afforded them through prostitution, immigrant smuggling, and opium and gambling operations. At the same time, the localization of power and profit produced infighting between Chinese associations. Bloody battles between Chinese association members in the 1880 s and 1890 s demonstrate these divisions, and the ensuing court cases, supplemented by local newspaper reports, shows how the Chinese population divided in its allegiances to various secret societies and clan and district associations. By the late 1890 s, Chinatown was clearly divided between those Chinese involved in illicit enterprises and those who sought to collaborate with white elites to end the battles between rival Chinese associations. 
I began collecting primary source materials for this thesis in November 2000 . I started by reviewing State District Court records for the fourth Oregon District at the Multnomah County Courthouse in Portland, Oregon. While these cases revealed aspects of Chinese social history, their frequency did not yield enough information for extended scholarly research. I then browsed the Multnomah County Circuit Court records archived on microfilm in the Multnomah County Courthouse files room. It was here that I stumbled across thousands of court records from county and circuit courts that involved Chinese men and women. I also dug into probate records, which revealed that Chinese were involved in estate and guardianship cases in addition to civil and criminal trials.

Because of the enormity and poor organization of the cases involving Chinese, I decided to approach the archive with both chronology and historical eras in mind. Out of the 1100 cases counted, I took a sample of 300 or so, 75 for each time period, divided into 1858-1870, 1870-1882, 1882-1892, and 1892-1910. I then reviewed carefully each of the selected cases to the end of understanding how trials at the local level changed as Chinese began arriving in Portland (1858-1870), settled (1870-1882), experienced exclusion (1882-1892), and moved their community into the twentieth century (1892-1910). I found, in the end, that the premises for civil and criminal cases - cases brought by individual Chinese against other Chinese, and by the City of Portland and the State of Oregon against Chinese defendants--did not change 
dramatically after the advent of exclusion. I did see an increase in habeas corpus cases after 1882 , but, for the most part, the reasons behind and the content of civil and criminal trials involving Chinese remained much the same through the exclusion period. At the same time, I did find that the demography of Chinatown had changed, and that these changes were reflected in patterns of litigation in the $1880 \mathrm{~s}$ and after. It is this change over time in demography, class, and relationships between Chinese and whites that directs this thesis. And it is the collection of local court records, teamed with English-language newspaper reports and missionary documents that inform the history of first-generation Chinese immigrants in Portland. 


\section{Chapter One}

A New Hierarchy:

Tradition, Adaptation, and Agitation in Portland's Chinatown

In a series of probate court cases tried in Multnomah County between 1870 and 1910, a pattern emerged that illuminates the adaptability of first-generation Chinese immigrants in the United States. Before the county court, Chinese immigrants, again and again, claimed the estates of fellow Chinese who had died while laboring for western railroad companies. ${ }^{\prime}$ Two representative cases took place in December 1884 and early January 1885 . In these cases John Wah filed petitions to gain full administrator status over the estates of two deceased Chinese laborers. At first glance, the estates seem small and inconsequential. That of Chow Chou Chong was valued at $\$ 25$, Chung Bok Quan's at only $\$ 5 .^{2}$ Regardless, Wah filed "notice of administrator" advertisements in The New Northwest, a small locally published newspaper as the law required, and submitted his petition to the court. In each instance, the court granted Wah full administrator status. ${ }^{3}$

Although the settlements appeared routine, the cases did not end when Wah gained administrator status. A few weeks later, attorneys representing other Chinese

\footnotetext{
' Probate records held at the Multnomah County Courthouse show that, between 1870 and 1910, Chinese immigrants filed many dozens of petitions claiming the estates of deceased Chinese. After reviewing over thirty such cases, it is clear that the majority of estate cases were settled in a similar fashion in the Multnomah county court.

${ }^{2}$ Chow Chou Chong, Est. 1127 (1885); Chung Bok Quan, Est. 1126 (1884) (hereafter Chung Bok Quan).

${ }^{3}$ Ibid.
} 
immigrants filed petitions to reverse the settlement in favor of Wah. ${ }^{4}$ Attorneys for I Chung Gok and Wah Sing filed a complaint charging that John Wah had lied about the place of death when he claimed that Chung Bok Quan died in Portland. The petition claimed, instead, that the deceased had died while laboring for the Oregon Railroad and Navigation Company (ORRNC). Furthermore, attorneys for I Chung Gok and Wah Sing stated that John Wah was neither a creditor entitled to collect debts after death nor a direct relative of the deceased. To the contrary, the petition for reversal held that Wah based his petition on fraudulent claims in order to extort money from the ORRNC.

In countering these petitions, Wah stated that his original claims were made "for the purpose of settling said estate honestly and faithfully." 5 He argued that I Chung Gok had organized a group of Chinese co-conspirators to claim brotherhood to the deceased fraudulently, gain control of the estate, and sue the railroad company for negligence. Such a claim would increase the deceased's estate's value from a few dollars to hundreds of dollars.

The case of Chung Bok Quan ended in February 1885 when John Wah received full administrative control over the estate of the deceased. With administrator status to the original $\$ 5$ estate, John Wah did in fact go ahead and sue the ORRNC for negligence in the death of Chung Bok Quan, successfully so as the

\footnotetext{
${ }^{4}$ My review of Chinese estate cases indicates that white attorneys knew they could profit from representing Chinese in negligence cases against railroad companies. For instance, Woodward \& Woodward, a well-known Portland law firm, frequently represented Chinese petitioners in estate cases and were paid directly from the money granted to Chinese plaintiffs.

${ }^{5}$ Chung Bok Quan.
} 
court awarded him $\$ 300$. It is apparent in this case, and dozens of others, that Chinese understood well how to make a profit off of the misfortune of their countrymen. Over several decades, Chinese turned similar negligence cases against railroad companies into a veritable racket. In some instances defendants went so far as to claim that they intended to transfer the money to the Consul General of the Empire of China in San Francisco for distribution to families of the deceased back in China. The likelihood that this actually occurred is slim. ${ }^{6}$ In most cases, Chinese were awarded over $\$ 300$ and, with minimal court and attorney fees, the profit margin was substantial.

Historians have long overlooked local court records and the detail they provide about the daily lives of Chinese. Crime, economic disputes, and conflicts between Chinese immigrants and Chinese and whites are embodied in these many hundreds of documents. The prohibition against Chinese immigrants testifying in court against whites - which was established by the 1860s in most states with substantial Chinese populations--has led historians away from looking at court records, particularly local records that shy away from habeas corpus cases, that would otherwise illuminate the Chinese immigrant experience. In actuality, in the nineteenth century Chinese

\footnotetext{
${ }^{6}$ Ibid.; See also, Way Sing, Est. 1125 (Jan., 1825); Chow Chou Chong, Est. 1127 (Dec., 1884); Low Chin, Est. 1606 (Feb., 1889); Chee Gim Sing, Est. 1972 (Dec., 1890); Fong Dun Hong, Est. 1064 (Sept., 1884); Kim Kim Been, Est. 1065 (Sept., 1884); Lee Fook, Est. 1066 (Sept., 1884); Wong Loy Hing, Est. 1067 (Sept., 1884); Bo Ah Fat, Est. 1068 (Sept., 1884); Kim Chung Hoy, Est. 1069 (Sept., 1884); Lee Ah Toy, Est. 1070 (Sept., 1884); Wong Ah Chew, Est. 1072 (Sept., 1884); Lee Ah Wong, Est. 1071 (Sept., 1884); The timing of these particular cases suggests that the Chinese laborers died in a single accident. However, cases span at least three decades and attest to the ongoing nature of negligence cases and the success Chinese had in turning profits from these cases. The claims by the plaintiffs to the estates suggests further that Chinese understood fully that fatal railroad accidents offered an opportunity to profit in suits against the ORRNC and other employers of Chinese.
} 
immigrants were constantly in court, where they regularly testified through white lawyers against whites as well as other Chinese. Chinese immigrants regularly sued whites for a variety of damages, criminal cases were brought against Chinese by the City of Portland and State of Oregon, and custody battles over Chinese women and children were common. ${ }^{7}$ And while racism and discrimination were not uncommon in courts, Chinese won a fair share of court battles and usually received sentences similar to those given whites. ${ }^{8}$

In these and other cases, the archives of Western courts shed light on the daily challenges that Chinese faced in Portland and the American West in general. While the existing literature about Chinese in the courts focuses on high-profile habeas corpus cases that Chinese filed during the era of exclusion, the records of daily events that plagued Chinese have, as yet, been studied only sparingly. ${ }^{9}$ The existing

${ }_{8}^{7}$ Custody cases are discussed in more detail in Chapter 2.

${ }^{8}$ Larceny and assault cases, especially, reveal the similar sentences given whites and Chinese. In most, the white or Chinese defendant receiving a small fine and time in jail; usually between a few weeks and up to one year in the state penitentiary, depending on the nature of the crime.

${ }^{9}$ Historians Alexander Saxton, Stanford Lyman, and Gunther Barth led the way in developing Chinese immigrant history in the west. Their studies focused on labor competition, racism and anti-Chinese legislation, and the differences and similarities between European and Chinese immigration in the nineteenth century. See Alexander Saxton, The Indispensable Enemy (Berkeley: University of California Press, 1971); Stanford Lyman, Chinese Americans (ABC-Clio Books: New York, 1974); Lyman, The Asian in North America (Santa Barbara, Calif.: ABC-Clio Books, 1977); Lyman, The Asian in the West (University of Nevada Press: Reno, 1970); Gunther Barth, Bitter Strength: A History of the Chinese in the United States, 1850-1870 (Cambridge, Mass.: Harvard University Press, 1964). For more on Chinese and habeas corpus, See, Charles J. McClain, In Search of Equality: The Chinese Struggle Against Discrimination in Nineteenth-Century America. (Berkeley: University of California Press, 1994); Lucy E. Salyer, Laws Harsh as Tigers: Chinese Immigrants and the Shaping of Modern Immigration Law (Chapel Hill: University of California Press, 
scholarly focus on the politics and jurisprudence of exclusion and discrimination unfortunately veils understanding of how Chinese experienced and overcame challenges emanating from their own ranks.

For instance, the county court archives of Portland, Oregon, in the years between 1860 and 1910 show that violence between Chinese was common. The community was not, as previous histories have suggested, a homogenous group working for the good of all. Rather, cases show that assault and larceny by Chinese against other Chinese immigrants was common. Other cases demonstrate the competition and violence between Chinese fighting for control of prostitutes and prostitution rings in Portland. County archives also reveal the development of a new

1995); John Wunder's studies of Chinese in the U.S. West use both local and federal court cases to illuminate the Chinese experience. See, esp., John Wunder, "The Chinese and the Courts in the Pacific Northwest: Justice Denied?" Pacific Historical Review,(1983), 191-211; Wunder, "Law and the Chinese on the Southwest Frontier, 1850s-1902, Western Legal History, 2 (1989), 139-158; Wunder, "Chinese in Trouble: Criminal Law and Race of the Trans-Mississippi West Frontier," Western Historical Quarterly 17 (1986), 125-141. For comparative studies of Chinese and other East Asian immigrants and Native Americans, see, Ronald Takaki, Iron Cages: Race and Culture in $19^{\text {th }}$ Century America (Oxford University Press: New York, 1979); Takaki, Strangers from a Different Shore: A History of Asian Americans (Oxford University Press: New York, 1987); Takaki, Journey to Gold Mountain: The Chinese in $19^{\text {th }}$ Century America (Chelsea House Publishers: New York, 1994). On European immigration in the 1830s see, Oscar Handlin, The Uprooted: The Epic Story of the Great Migrations That Made the American People, Second Edition (University of Pennsylvania Press: Philadelphia, 2002), John Higham, "Integrating America: The Problem of Assimilation in the Nineteenth Century," in Jon Gjerde, Major Problems in American Immigration \& Ethnic History (Boston: Houghton Mifflin Company, 1998), pp. 16-22; Higham, Send These to Me: Immigrants in Urban America, Revised Edition (Baltimore, Md.: John Hopkins University Press, 1984); John Bodnar, "Immigration Portrayed As an Experience of Transplantation," in Gjerde, ed., Major Problems in American Immigration \& Ethnic History, pp. 8-16; Kathleen Neils Conzen, "The Invention of Ethnicity: A Perspective from the USA," in Ibid., pp. 2231 . 
social hierarchy among Chinese immigrants. As immigrants arrived in Portland, they adapted their social and economic relationships to fit new challenges. Out of this process of adaptation developed a new merchant elite that was, for many decades, highly active in the courts at a variety of levels. To understand the internal challenges-within Chinatown-we must focus our attention on individual communities such as Portland, Oregon. Archival material from county, district, and circuit courts help illuminate some of the common challenges that Chinese immigrants experienced and some of the ways in which they addressed them. ${ }^{10}$

This chapter explores three aspects of the Chinese immigrant experience in Portland. It first discusses the demographic structure of Chinatown between 1850 and 1890. When immigrants settled in Portland, they constructed a geographically isolated enclave. There they established businesses along lines similar to those found in southern China, the origins of most Chinese immigrants who came to the U.S. West, but, at the same time, they adapted elements of their community to the specific conditions of American society in the western United States. Second, this chapter focuses on how adaptation shaped the merchant and laboring classes in Chinatown, for both laborers and merchants adapted their roles in the United States to fit the needs of

${ }^{10}$ For community-specific studies on Chinese immigrants see, Sandy Lydon, Chinese Gold: The Chinese in the Monterey Bay Region (Capitola, Calif.: Capitola Book Company, 1985); Jeffrey Barlow, China Doctor of John Day (Portland, Ore.: Binford \& Mort, 1979); Sucheng Chan, This Bittersweet Soil: The Chinese in California Agriculture, 1860-1910 (Berkeley: University of California Press, 1986); Xinyang Wang, Surviving the City: The Chinese Immigrant Experience in New York City, 1890-1970 (Lanham, Mass.: Rowman \& Littlefield Publishers, 2001); Sarah M. Griffith, "Ethnicity, Solidarity, and Tradition: A Study into the Dynamics and Complexities of the Chinese Immigrant Community in John Day, Oregon, 1860-1906" (Undergrad. Thesis, Lewis and Clark College, 2000). 
white businesses - the primary source of employment for thousands of Chinese immigrants. As these two groups adapted, they simultaneously altered the relationship between Chinese laborers and merchants. A hierarchy of power developed in Portland's Chinatown that placed merchants at the top of the immigrant social ladder, created a dependency on the part of Chinese laborers, and linked both merchant and working class Chinese to the corresponding white power hierarchy in significant ways. Third, while a complex process of economic adaptation shaped the lives of Chinese immigrants, uneven cultural assimilation to Western practices, especially in regard to traditional religious beliefs and social associations, created resentment between Chinese immigrants and led to internal violence among them.

\section{Demographics}

It is important first to understand when and from where immigrants to Portland's Chinatown came. It is also important to note the demographic makeup of the first-generation immigrants who settled in the urban hub. Portland's Chinese enclave developed in a pattern similar to other cities in the North American West. Chinese arrived in Portland as early as 1851 , with the establishment of steamer trade between China and Portland via San Francisco. In the early 1850s, most Portland Chinese were merchants and businessmen, like Mr. Sung Sung, who established the Tong Sung boarding house and restaurant on Second Avenue.. "

"Chinese women, although in small numbers, arrived in Portland by the $1860 \mathrm{~s}$. As in other U.S. West Chinese enclaves, most Chinese women in Portland lived as prostitutes but others came as wives of Chinese men. For instance, in the estate trial 
These early Portland merchants—and prostitutes—catered to a migratory

Chinese population that passed through Portland on its way to rural areas where mining and other laboring opportunities existed. ${ }^{12}$ By 1857 , an urban laboring population became evident as Chinese found employment as cooks in restaurants and in the homes of wealthy whites. The 1860s brought more Chinese to Oregon, especially after the 1858 discovery of gold in southern Oregon. Immigrants migrated north to the urban hub of Portland. At the same time, a Chinese immigrant merchant class developed providing goods and services to the growing migratory and permanent populations. By 1870 the Chinese had become the largest ethnic group in Portland, and their community spread from Ash Street to Salmon Street and from the waterfront to Third Avenue.

In 1870, Multnomah County, where Portland was located, tallied 496 Chinese immigrants. By 1880 , that number more than doubled to 1,961 , and the average age of Chinese residents was twenty-six. Twenty to thirty-year old males dominated Chinatown; like other Chinese immigrant communities in the North American West,

Ah Jack, Ah Jung, the wife of the deceased, petitioned the court for administrator status of her husband's estate. In this case, the estate was quite large, totaling over $\$ 1000$. Ah Jung, in court against a handful of Chinese creditors, failed to win her case. See, Ah Jack, Guar. Est. 702 (1857); For information on other Chinese immigrant enclaves and Chinese women living in those regions, see Anne M. Butler, Daughters of Joy, Sisters of Misery: Prostitutes in the American West, 1865-90 (University of Chicago Press: Chicago, 1985).

${ }_{12}$ Prior to the 1880 s, the majority of Chinese immigrants listed in census records lived in rural regions of Oregon. When rural industry took a downturn in the $1880 \mathrm{~s}$, many Chinese migrated to Portland, San Francisco, and Seattle, swelling the populations of these urban Chinese enclaves into the many thousands. 
women composed only a small portion of the population. ${ }^{13}$ By 1880 , Multnomah, Wasco, and Clatsop County's Chinese immigrant population had increased to 2,317 and by 1890 the number totaled 5,148. In 1890, then, Chinese Portlanders accounted for more than 10 percent of the approximately 46,000 people in the city. ${ }^{14}$

As Chinese immigrants became a permanent presence in Portland they opened businesses, worked as laundrymen and cooks, and served as domestics in the homes of wealthy whites. Others resided in the cramped boarding houses of Chinatown until they found work through one of the many Chinese labor contractors, at which time they moved to shanty camps in outlying areas. ${ }^{15}$ Immigrants came to the city by ships from China and San Francisco or by land from rural regions throughout the Far West. In the city, they surely welcomed the familiar sites, sounds, and people from home that urban concentration afforded. For instance, during their stay in Portland, immigrants could view a traditional opera at the Chinese Theater, play card games like

${ }^{13}$ In 1870 , for instance, out of the 496 Chinese enumerated by census takers, only 41 , or 8 percent, were women and the majority of these were listed as prostitutes. The statistics presented here document those Chinese who lived in Multnomah, Clatsop, and Wasco Counties-all but 40 of which lived in Multnomah County and, more than likely, in the city blocks that made up Chinatown.

${ }^{14}$ See Nelson Chia-Chi Ho, "Portland's Chinatown: The History of an Urban Ethnic District," (Portland, Ore.: Bureau of Planning, City of Portland, Oregon, 1978); P. Scott Corbett and Nancy Parker Corbett, "The Chinese in Oregon, c. 1870-1880," Oregon Historical Quarterly, (1977), 73-85. The 1880 census listed no alteration in the female population in Multnomah, Wasco, and Clatsop counties. In fact, in 1880, over 98 percent of the Chinese immigrant population was male. The Corbetts documentation of the Chinese population through census records from Wasco, Multnomah, and Clatsop Counties provides the best available estimate.

${ }^{15}$ By the 1870 s Chinese immigrants had spread out to areas beyond Chinatown. Photos collected at the Oregon Historical Society show small shacks where Chinese vegetable farmers lived, directly below some of Portland's most well-known and wealthiest businessmen. Court records show that Chinese spread to the east side of the Willamette River as well. 
Fan Tan and Keno, visit the Chinese joss house for worship, or purchase time with Chinese prostitutes who were indentured in the squalid brothels that dotted Chinatown. In the ground level storefronts of Chinatown, businesses sold items like dried shark's fins, preserved eggs, geese and ducks (either live or preserved in oil), and fruits and confections. In Chinese drug stores immigrants could purchase eclectic items such as dried reptiles, preserved snakes, elk horns, ginseng, and a large assortment of medicinal herbs. Vegetable stalls, fruit stands, and chicken coops undoubtedly reminded immigrants of home, as did the crowded streets that bustled with laundry operators carrying poles and baskets and men going here and there for business and pleasure. ${ }^{16}$

Above the street-level storefronts were boarding houses where permanent and temporary residents rented rooms. The crowded living quarters were plagued by theft and burglary; in these quarters up to 20 persons might be crowded into a small 12 by 20 foot room. ${ }^{17}$ On festival days and during funeral services Chinese flooded into the streets of Chinatown dressed in traditional smocks and caps. From the balconies of dwelling houses they would watch the processions as they wound through Chinatown. English-language newspapers frequently described these burial processions, remarking on the exotic practices of mysterious Orientals. In an 1891 article from The West

\footnotetext{
${ }^{16}$ Ho, "Portland's Chinatown," 13.

${ }^{17}$ Records from the Multnomah County District Court show that burglary and assault was common in Portland's boarding and dwelling houses, both white and Chineseowned. For more on the types of burglary and violence and punishment, see State of Oregon v. Yee Chung Chik, Judgment 9976; State of Oregon v. Su Sin, Judgment 7109; State of Oregon v. Ah Wong, Judgment 6098; State v. Jim Loon, Judgment 6099, State of Oregon v. China Joe, jointly indicted with Ah Quong, Judgment 7111.
} 
Shore, a locally-published society magazine, a reporter described, with both confusion and admiration, the events that accompanied Chinese New Year. "At night the streets are brilliant with a multitude of many-colored, balloon-shaped lanterns of all sizes. It is between the hours of six and eight that the authorities permit the firing of crackers, and then the noise is like that of a battle." 18

Despite Portlanders curiosity about the Chinese immigrant population, whites more generally frowned on and feared the Chinese people, their laboring class particularly, and their habits and customs. English-language newspapers complained about the crowded living quarters in Chinatown, stereotyping Chinese, especially nonmerchant Chinese, as morally depraved and a threat to the moral well being of American society. Complaints about squalid living conditions and the destitute lives of Chinese women appeared often in the pages of the Daily Oregonian. A characteristic 1865 article stereotyped Chinese men as "drunken loafers" and labeled Chinese prostitutes "disgusting specimens of decrepi[t] humanity" who were given police whistles to call on officers while "decent Americans" had to hunt for protection against violent Chinese men. ${ }^{19}$

In the legal arena, anti-Chinese sentiment was clearly represented through a series of laws. Early Oregon laws that targeted Chinese were similar to those passed in California. In June 1873, the Portland city council passed the "cubic air" ordinance that required the chief of police to arrest all persons living in a building that contained less than 550 cubic feet of air for each occupant. Fifty-two Chinese violators were

${ }^{18}$ The West Shore, "Chinese New Year and Theater," Feb. 28, 1891.

${ }^{19}$ Daily Oregonian, Nov. 22, 1865. 
arrested on June 26 and 27, 1873, and all but two paid a five-dollar fine. In February 1874, the city council prohibited the cutting of wood on sidewalks. In April 1874, it prohibited the carrying of swill or other offensive material without being properly covered. In November 1877 it prohibited the smoking, buying, or bargaining for opium (even through national law did not make the supply and distribution illegal until 1906). Attempts were made to impose a prejudicial tax on Chinese washhouses in 1863 and 1865. However, Mayor Henry Failing vetoed this act because of its discriminatory nature. ${ }^{20}$ These measures were justified on the grounds of public safety and fire hazards, but racial resentment resonated from them loudly.

As early as the 1860 s, conflicting opinions developed over the role Chinese would play in the United States generally and Portland specifically. A sharp line divided those whites who needed inexpensive labor to supply their businesses and working class whites who saw the Chinese as competitors for jobs. A third opinion was voiced by social reformers who viewed the Chinese as a peril to the moral welfare of the American mainstream. In the 1870s, perceived labor competition added fodder to the already hot debate over the legality of Chinese immigration. As the U.S. Congress began to consider seriously immigration restrictions against the Chinese, the

${ }^{20}$ Early anti-Chinese laws in Oregon Territory included an 1857 ordinance that required every Chinese miner to pay the local sheriff a monthly tax of two dollars; failure to pay this tax permitted the sheriff to seize all property and sell it within the hour to the highest bidder. Additionally, according to the Oregon Constitution, Chinese were prohibited from voting. Oregon state law prohibited Chinese residents from owning real estate or working mining claims. After 1862-63, Chinese were forced to pay an annual tax of five dollars or face arrest and forced labor on public projects. Charles A. Tracy, "Race, Crime and Social Policy: The Chinese In Oregon, 1871-1885," Crime and Social Justice, (1980), pp. 11-25. 
Daily Oregonian expressed the local view. In a series of heated editorials, an Oregon proponent of exclusion wrote,

every other element that comes to our shores is soon transfused into our own population... [but] Chinese are an exclusive people, and are practically incapable of change or improvement....New ideas find no way into their minds.... They are not an assimilable element, and they come in contact with our own people in a way which cannot in the long run be favorable either to morals or prosperity.

The author continued that "there are branches of employment in which Chinese may engage without coming in competition with white labor, but these branches are not very numerous, and there are Chinese enough among us to fill them all for the present." 21

Calling himself "Justice," a critic of this editorial, and of a corresponding antiChinese meeting, wrote in response: "If the late demonstration against the Chinese is in the interest of American labor, then why not extend the condemnation to all foreigners and to labor-saving machinery." On the moral character of Chinese, Justice stated, "It is pitiable to see and hear swaggering, drunken fellows, almost rotten with disease, [t]alking of the bad moral influence of the Chinese. I venture to assert that nine out of ten who are engaged in this crusade would hire Chinamen if their interests could be served in that way."22 Editorials such as these illustrate how whites often fused questions of moral authority with labor competition, and how intertwined the

${ }^{21}$ Daily Oregonian, Mar. 22, 1879.

${ }^{22}$ Ibid. 
two were in the movement for Chinese exclusion, providing a mutually reinforcing justification for all groups that promoted exclusion. ${ }^{23}$

Although they failed to recognize it, editorial debates such as these highlighted an important fact. In regards to labor and class, Portland's Chinese immigrant population was not a homogenous entity. Chinese immigrants in Portland included, in addition to common laborers, middle-level merchants and labor contractors and a wealthy merchant elite. Some Chinese came to Portland with business savvy developed in China. Others originated from agricultural regions and understood irrigation and damming techniques that aided them in mining. Chinese immigrants adapted these skills to meet labor and business demands, to overcome challenges they faced in a hostile environment, and to take advantage of new economic opportunities.

These local adaptations, in turn, prompted development within Chinatown of a social hierarchy different from that which immigrants had known in China. In China, Confucian moral order generally frowned on merchants who focused their lives on the pursuit of personal wealth. In the U.S. West, traditional Confucian social hierarchies were turned on their head as families were left behind and merchants came to prominence among immigrants who relied on that class for financial assistance, labor contracting services, and mediation services that protected laborers from unfair

${ }^{23}$ Opinions about Chinese immigration conflicted even after the passage of the Chinese Exclusion Act in 1882. Anti-Chinese labor activists complained that Chinese competed with whites for labor while social reformers complained of the moral depravity of Chinese laborers and prostitutes. Additionally, whites cited Chinese immigrants unwillingness to assimilate to American religion, the English language, and mainstream customs. Many assumed that Chinese were inherently incapable of assimilation due to cultural heritage and a continued association with the dynastic leadership in China. 
treatment by white employers. ${ }^{24}$ In these ways, Chinese merchants moved to the top of the social ladder while laborers, the majority of the immigrant Chinese population, remained at the lower end. This hierarchical restructuring affected the way Chinese associated with one another between Chinatown's development in the 1850s and through the 1910 s.

\section{The development of a merchant elite in Chinatown}

In his article, "The Origins of Chinese Emigration to California Reconsidered," historian Yong Chen has studied the development of the Chinese immigrant merchant class in the United States. Contrary to scholars who have depicted the Chinese as a population forced out of their homeland by social, political, and economic strife, Chen shows that many Chinese willingly left China to pursue opportunities in the North American West, despite well known perils awaiting them. Chen focuses on the merchant class and how these men had derived their understanding of business, particularly western-style business, in the southern delta region of China.

This region was home to China's oldest and best-developed market-oriented economies. When British, French, and, later, U.S. merchants entered the China trade, merchants were ready and willing to learn from their foreign counterparts. The

${ }^{24}$ As I mention below, a Chinese merchant class had developed in the southern delta regions of China. These merchants held much power over local economies and probably did not experience the same Confucian hierarchy as in other regions of China where merchant trade, and especially trade with wealthy Western traders, was not as important to local economies. However, Confucian thought, generally, frowned on those who focused more on personal wealth than personal moral cultivation. See Jonathan D. Spence, The Search for Modern China (New York: W.W. Norton \& Company, 1990), esp. 90-193. 
development of a merchant class in southern China prepared merchants and experienced wage-earning laborers for survival, even success, in the United States' market economy. ${ }^{25}$ Furthermore, as western European and American fur traders entered these southern China markets in the late eighteenth and early nineteenth centuries, the Pearl River delta region became a focal point of interaction between China and the West. Chinese in this region were the first to learn and take advantage of the 1848 gold discovery in California. And as more traders and missionaries settled in the southern delta region of China, English-language newspapers also established a place in the greater Chinese society. Papers such as the Alta California, the San Francisco Daily Herald, and the Daily Journal of Commerce made their way into the hands of Chinese merchants and skilled laborers. Articles reporting on the opportunities in California provided a catalyst for early Chinese immigration to the western United States.

We can assume that Chinese merchants and laborers, who spread north from California to Oregon and, eventually, Portland, arrived with prior knowledge of the opportunities available to them and developed their communities in light of this knowledge. Merchants, for instance, provided basic services to the local Chinese community. As immigrants arrived on steamships from San Francisco and Seattle-as well as directly from southern China-merchants served as preliminary hosts. They met new immigrants at the docks and acquainted them with their new surroundings.

${ }^{25}$ Yong Chen, "The Internal Origins of Chinese Emigration to California Reconsidered," Western Historical Quarterly, (1997), pp. 521-546. Chen expanded this analysis in Chinese San Francisco, 1850-1943: A Trans Pacific Community (Stanford, Calif.: Stanford University Press, 2000). 
They also provided immigrants with financial and material assistance, especially when arriving Chinese shared a common regional origin in China. ${ }^{26}$ Merchants brought to their role a unique understanding of the challenges immigrants confronted when associating with the white community. Merchants came to possess an intricate understanding of how businesses, government, and law operated in the United States. Perhaps most importantly for the hundreds of Chinese laborers who, in the last half of the nineteenth century, arrived in Portland each year, merchants served as labor contractors. They controlled the placement of laborers in white businesses and helped protect laborers' rights and interests on the job.

Merchants maintained a dominant role in their relationship with laborers. This was especially the case as the number of Chinese laborers increased while the wealthy merchant population remained fairly static. At the same time, merchants relied on the constant influx of Chinese immigrants whose demand for services only Chinese merchants could provide. For instance, in 1870, Chinese in Multnomah, Clatsop, and Wasco counties numbered 496; of these, more than 200 were listed as laborers. By 1880 the Chinese immigrant population had almost quadrupled to 1,961 , with more than 600 identifying themselves as laborers. During the same two periods, however, the number of merchants increased by only five, from six to eleven. ${ }^{27}$ This small, and virtually unchanging number of merchants gained power as the immigrant Chinese

${ }^{26}$ Chinese district associations helped members find employment and acquaint themselves with their new surroundings. District associations based membership on a shared provincial connection in China. Clan associations, another traditional association with similar financial and social functions, based membership on direct blood ties.

${ }^{27}$ Corbett and Corbett, "The Chinese in Oregon." 
population, especially laborers, burgeoned. They brokered the labor of hundreds of men and, at the same time, provided them with goods and services. Both Chinese laborers and white-business owners eventually became reliant on the services-goods, jobs, and labor-provided by Chinese merchants. And over time, the adaptability of merchants increased their influence among both Chinese and white populations.

Chinese merchants in Portland adapted quickly to their new role inside the immigrant community. They first saw and met the demand for labor, and, as the immigrant Chinese laboring population grew, they met the demand for goods and services it created. In business, merchants fused their retail stores with labor contracting services. Contractors like the Wing Sing \& Company helped immigrants both to find jobs and to assure that, once on the job, laborers were paid fairly and supplied with necessary tools, clothing, and food. Contractors placed anywhere from a few to hundreds of Chinese laborers with white logging and railroad companies. The contracts between the white and Chinese companies assured certain things for both the laborer and the white owner. Merchants assured laborers their provisions and promised whites that laborers would not strike while on the job. In addition, merchant contractors helped laborers fight their white employers when they were not paid. In fact, in numerous cases Chinese merchant contractors brought white businesses owners to court after they failed to pay laborers for work completed. ${ }^{28}$

${ }^{28}$ For details of contracts and compensation cases see, Kwong Loon Kee \& Company v. C.Y.S. Sprague Company, Judgment 7736; Lee Chew v. Wing Hing Chewey, Judgment 9038; Hop Chong \& Company v. Todd \& Biven, Judgment 9192; Gai Kee v. J.S. and C.C. Miller, Judgment 19597; Chung Lung v. James Cooper, Judgment 7614. 
For laborers, legal support was crucial to their survival in the United States.

Merchant contractors had both the financial capacity and social status to bring the law to bear on white employers. Merchant contractors were also familiar with the U.S. legal system and aligned themselves with one another in court cases against white employers. For instance, court documents show that merchants often served as sureties in legal cases involving Chinese, assuring both the financial capacity and testimonial reliability of fellow merchants and laborers. In addition, by understanding the framework of U.S. law, these merchants could and did hire high-profile white lawyers to defend Chinese in court. ${ }^{29}$ These white lawyers made careers helping defendants file writs of attachment against the property of white companies and assisted them in the often-lengthy legal processes that accompanied breach of contract cases. Without the assistance provided by their Chinese contractors, laborers would have been incapable of retrieving unpaid wages from white employers.

In a parallel way Chinese merchants provided services to the white community. Unlike laborers, merchants adapted quickly and thoroughly to the American economic and legal environment. Merchants did not threaten competition, as did laborers. Furthermore, merchants represented a common entrepreneurial ethic embraced by whites. Most Chinese merchants understood and used the English

${ }^{29}$ Chinese in Portland generally used the same lawyers for their cases. These included A.H. Tanner's firm, Senator John Mitchell's law firm, Woodward \& Woodward, and C.A. Mulkey's firm. This patter is similar to that described by Lucy Salyer in her study Chinese immigrants in San Francisco, especially in cases of habeas corpus. See, Lucy Salyer, Laws Harsh as Tigers and Salyer, Entry Denied: Exclusion and the Chinese Community in America, 1882-1943 (Philadelphia: Temple University Press, 1991). 
language; they were consequently seen as a group more capable of adapting to the American mainstream. Yet what whites were less willing to realize was that these same merchants who spoke English and adapted to the American business environment were, on the whole, more closely tied to the cultural norms of Chinese society. Merchants were more likely, for instance, to educate their children in English-language schools but less likely to abandon ties to their responsibilities to family and cultural tradition in China. Chinese merchants were also those who headed traditional clan and district associations, as well as secret societies, all common in China, once they were living in the United States. Simply put, Chinese merchants served as the leadership for and financial backers of the traditional elements of Chinese society that were transplanted, and cultivated, in the U.S. West.

Specifically, Chinese merchants maintained financial ties with family in China, encouraged the return of remains of immigrants who died in the United States, and provided funds for the maintenance of traditional burial plots in their homeland.

Merchants maintained strong connections, economic and cultural, with China at a time when whites chastised immigrants for their unwillingness to become a part of the U.S. economic system. ${ }^{30}$ At the same time that these Chinese merchants sought to maintain the traditional framework of Chinese tradition and responsibility in the United States,

\footnotetext{
${ }^{30}$ In some cases, whites combined their dismay for the social and economic customs of Chinese in defending their anti-Chinese sentiment. For instance, "It is one of the grounds of complaint against John Chinaman that he lives in the poorest possible style, thus not contributing to the support of those thousands of industries that go to sustain our complex industrial system and give work to the mechanics; and, doubtless, this is a just cause of objection since the best citizen is he who spends his money and thus returns it to the channels of trade and provides work for thousands," The West Shore, Feb. 28, 1891.
} 
outside influences, especially white missionaries, permeated the cultural and geographic borders of Chinatown. With this permeation developed a division between Chinese who maintained Chinese institutions and beliefs and those who chose assimilation over tradition.

\section{Divisions inside Chinatown}

As the Chinese population in Portland grew in the last half of the nineteenth century, so too did the cultural infrastructure of the community. Immigrants brought with them social institutions and, similar to their businesses, adapted them to fit new conditions. For instance, when immigrants died in the United States, merchants, in connection with friends of the deceased, usually coordinated the shipping of their remains to family in China. Additionally, merchants served as go-betweens for families in China and their relatives in the United States. When ancestral burial sites and temples in China needed renovation, merchants collected funds from relatives that resided in the United States. ${ }^{31}$ Merchants also led clan and district associations that

${ }^{31}$ In John Day, Oregon, well-known merchants, Lung On and Ing Hay, were frequently called upon to assist in financing the renovation of ancestral burial sites and temples in China. Requests for funds by families in China were were often sent to Chinese merchants in the U.S. West who could locate sojourning immigrants. Once requests were made, merchants and clan leaders organized contributors and sent their offerings to the family. For letters detailing this occurrence see, Kam Wah Chung Collection, Oregon Historical Society, Microfilm 74, Reels 1-6. 
formed the backbone of social life in Portland's Chinatown. In these ways, merchants nurtured and perpetuated trans-Pacific connections. ${ }^{32}$

While merchants oversaw the maintenance of cultural institutions and transPacific relationships they also accepted a certain level of cultural adaptation. For instance, first-generation immigrants who started families in the United States often sent their children to English-language schools run by European American religious and social reform organizations. Laborers also understood the benefits of learning English, but, because most laborers were sojourners without family in the United States, the importance they placed on learning English was not as great and served as a temporary means to an end and as a way to help them cope with discrimination in the United States. The balance between assimilation and tradition posed particular challenges for Chinese immigrants and created division among their ranks. As white social reform movements increased in the 1880 s and 1890 s the pressure for immigrants to assimilate also accelerated. The decision to assimilate proved especially trying for those immigrants who valued cultural norms and the preservation of ethnic identity and autonomy.

For many immigrants, the retention of Chinese language, religion, and social institutions marked the fundamental features of both personal and ethnic identity. As U.S. laws increasingly attacked Chinese in the United States, many Chinese immigrants embraced these traits as a tool to maintain the survival of immigrant

${ }^{32}$ For more detailed discussion on the transplantation of traditional social networks to Portland see Chapter 4 below; Chen, Chinese San Francisco; Lyman, The Asian in North America, pp. 88-118. 
culture. For instance, prostitution as a social, and economic, institution in the immigrant culture was threatened in 1875 when Congress passed the Page Act. The Page Act banned the immigration of Chinese women to the United States but could not diminish the importance of prostitution within the immigrant culture. After the passage of the law, Chinese men continued to battle in the U.S. legal system to maintain control of prostitution networks while the white majority looked on in general frustration. The 1882 Chinese Exclusion Act banned non-merchant immigrants from coming to the United States, but it could not quell the social networks that, operating underground, assisted illegal immigrants in entering the United States. And the 1888 Scott Act and 1892 Geary Act tightened exclusion by requiring immigrants to register themselves in the United States. Yet these laws could prohibit neither the retention of native language nor the immigrant social institutions that helped Chinese in their cases on writs of habeas corpus in U.S. courts. In these ways, retention of social norms and language were important to incoming Chinese as well as those already battling discrimination in the United States. Chinese in the Unites States who abandoned cultural traditions were often viewed as selling short their fellow countrymen.

Beginning in the $1860 \mathrm{~s}$, social reform movements began to target these elements of Chinese immigrant culture in Portland. European American religious organizations targeted Chinese prostitution and vice and encouraged language acquisition in the hope that language would lead to conversion and eventually be transmitted to China via Chinese immigrants who had sojourned in the United States. 
Missionaries - and so- called benevolent organizations - penetrated the geographic borders of Chinatown, and approached those Chinese who seemed most willing to adopt Christianity and white American culture. As early as 1869, the Daily Oregonian reported that the Young Men's Christian Association had opened a Chinese language school in Portland and noted (with pleasure) that ten Chinamen had applied for admission and that some of these already had a working knowledge of the English language. These Chinese the Daily Oregonian praised for "marked quickness" in learning the alphabet; at the close of the lesson of one hour the newspaper preened that the students could "point to any letter of the alphabet which might be named." 1876, another Daily Oregonian article reported that several Chinese converts held a celebration for new Chinese baptisms, and an 1877 report from Salem noted that a Chinese language school had been established in that town, welcoming all Chinese who wanted to learn English to attend. ${ }^{34}$ Religious organizations were quite open about their goal of converting Chinese to Christianity through language schools and were confidant in their eventual success. As one reported, "We have a substantial proof that the hearts of the Chinese are not incapable of gratitude, liberality and affection. Treat them well; teach them the knowledge of our language, and lead them to Christ, and all will be well." 35

While most Chinese used the mission schools for their own purposes-the practical benefits of learning English-some did in fact convert to Christianity. Some

${ }^{33}$ Daily Oregonian, Aug. 17, 1869.

${ }^{34}$ Ibid., Nov. 14, 1876; May 17, 1877.

${ }^{35}$ Ibid. 
immigrant Chinese in Portland were baptized, and others regularly attended services and practiced street preaching inside Chinatown. ${ }^{36}$ Still other Chinese immigrants joined "Christian scholar societies" and were praised for their devotion. Discussing the choice of one male Chinese immigrant to adopt Christianity, the Daily Oregonian reported: "Many eyes were wet with tears, as he told of his sufferings, caused by his heathen father after he professed Christianity." Knowing Chinese risked persecution when they converted to Christianity, one missionary stated, "Several [Chinese immigrants] lost situations on which they depended for support and one confessed that he came after 'cruel scourging,' publicly to give himself to God." ${ }^{37}$ In a published

${ }^{36}$ In a November, 1875, Daily Oregonian article, the Baptist Church noted that, "The school commenced with 75 Chinamen present and had on an average, 45 during the first six months...ten members of the school had publicly professed faith in Christ. Twenty had formed themselves into a Christian Knowledge Society," Daily Oregonian, Nov. 23, 1875. The Baptist mission in Portland had at least 20 Chinese students in the late 1870s that formed themselves into a "Christian Knowledge Society" which met weekly to study the Bible. It was reported in one publication that "in this society all gambling, drinking, visiting houses of ill-repute and opium smoking was strictly prohibited....From the moment of their first examination of the Bible, Joss is neglected". Baptist Annals of Oregon, 1844 to 1900 (2 vols., McMinnville, Ore., 1905), 1: 203-204.

${ }^{37}$ In a 1905 published account from the Baptist Annals of Oregon, Rev. C.H. Mattoon reported on a similar case of a Portland Chinese man who had converted to Christianity. "After three months' attendance, one of the pupils left for Astoria [Oregon]. His heathen uncle had removed him from all Christian influence, and threatening to disown him if he did not forget the school. His teacher wrote him a Christian letter. In his reply, he said, 'I know you can only pray for me. I hope you will ask God to keep me, for I am walking in the way of difficulty, and I had myself ready to ask Him to help me to walk in the King's highway. I pray that you will help me to know Christ, and that I may be able soon to enter the wicke[d] gate." And another report from the same publication noted that there were ten Chinese enrolled at the Portland Episcopal school in 1875. Opposition to their involvement in the school was so strong that five of the Chinese converts left the church with only three of those five returning at a later date. Two of the three returnees "lost good positions as clerks for their heathen relatives, and considerable money for their course." Ibid. 
account, another missionary reported, "After the Baptism of the converts, many of the regular pupils stayed away for a time, intimidation and threats of violence being used to prevent their coming, but afterwards they returned." 38 In the streets of Portland's Chinatown, many faced taunts, and street preachers were sometimes run out of the Chinese district by their fellow countrymen. In other instances, even more serious repercussions were felt, as an 1868 newspaper article noted: "A night or two since an attempt was made by several Chinamen on Alder street, to murder one of their countrymen, on account of some disagreement concerning religious belief." 39

Throughout the 1870 s, newspapers continually reported violence against Chinese who converted to Christianity and embraced aspects of American culture. A particularly revealing case took place in the Portland Chinatown joss house in October of 1878. In this case, Charley Lee Quong, Lee Jaw, and Lee Jong murdered Chin Sue Ying, purportedly because of the latter's conversion to Christianity. Chin Sue Ying made no secret of his conversion and frequently visited Chinatown and the local joss house to express his devotion to Christianity. This persistence led to his murder in the joss house that October night.

The original conflict between two groups of Chinese began several days before the murder when Chin Sue Ying visited the joss house and intentionally knocked over a religious pot that sat on the joss house alter. Other Chinese in the joss house quickly demanded that Chin Sue Ying leave. When he refused, Lee Quong went down to the street and asked a police officer to remove Chin Sue Ying from the joss house. The

\footnotetext{
38 Ibid., p. 203.

${ }^{39}$ Daily Oregonian, July 10, 1868.
} 
officer asked if he wished for the intruder to be arrested, but Lee Quong responded no, "I know him, I'll have him arrested to-morrow." ${ }^{\text {40 }}$ However, Lee Quong did not go on to have Chin Sue Ying arrested, and Chin Sue Ying returned to the joss house on the evening of October 3, accompanied by two other Chinese men, allegedly to deface the altar.

In later court testimony, Chin Sue Ying's companions that night, Wo Jung and Lun Sing, testified that they and Chin Sue Ying had, prior to the affray, been scholars at the Chinese mission school in Portland. When the three men went to the joss house that evening, Chin Sue Ying apparently approached the altar and attempted to throw a piece of raw meat at the temple idols. In reaction, Lee Jong grabbed Chin Sue Ying's arm and yelled for him to stop. When he refused, Lee Jong drew a hatchet from his coat and struck Chin Sue Ying over the head. The two men battled for control of the hatchet. Chin Sue Ying managed to wrest it from the hands of Lee Jong but not before Lee Jong pulled a pistol from under his clothes and shot Chin Sue Ying. Lee Jong shot Chin Sue Ying and then fled the building with his companions.

During the trial, witnesses for the state testified to the fact that the confrontation at the Chinese joss house had been building for some time. During Chin Sue Ying's first altercation at the joss house, Lee Quong had yelled epitaphs at Chin Sue Ying that translated roughly to "a man who acts like a prostitute"-a reference to

${ }^{40}$ State of Oregon, Respondent, v. Charley Lee, Indicted under the Name of Charley Lee Quong, and Ah Lee, Indicted under the Name of Lee Jaw, Jointly Indicted with Lee Jong, Appellants, Oregon Reports, vol. 27, 237-258 (hereafter State of Oregon v. Lee). 
Chin Sue Ying's conversion to Christianity. ${ }^{41}$ Witnesses also testified that, when Chin Sue Ying entered the joss house the next evening, the men already there had planned to attack Chin Sue Ying if he reappeared. The law firm of Dolph, Bronaugh, Dolph and Simon and Whaley \& Fechheimer, who represented the non-Christian Chinese defendants, argued that the entire affray was accidental, a product of the heat of passion, but the district attorney, John F. Caples insisted otherwise, convinced the judge and jury that, because the two groups had fought before and the accused were carrying weapons in a house of worship, the murder of Chin Sue Ying was clearly premeditated. ${ }^{42}$ Each of the accused was found guilty and sentenced to death by hanging.

For Chinese on both sides of the religious line, confrontations similar to this continued into the twentieth century. Pressures within Chinatown to maintain immigrant identity, culturally and economically, weighed heavily. For those immigrants who abandoned custom, language, and association with other Chinese, the cost could be deadly. Those who embraced publicly the American mainstream faced, at the least, ostracism from their own countrymen. And in an immigrant society that defined itself through its internal cohesion and the retention of custom, this ostracism constituted veritable exile.

${ }^{41}$ State of Oregon v. Lee, 250.

42 The judge and jury ruled, specifically, "Direct proof of deliberation and premeditation is not required, but may be inferred from proven facts. Three men, all armed with deadly weapons, made a simultaneous attack upon a third, in a Chinese Joss-house, and killed him-one having approached from behind, and without saying a word, struck him a deadly blow on the head with a hatchet, while the others fired two shots into his body in rapid succession." It was held that these facts warranted the jury in concluding that the killing was premeditated. Ibid. pp. 214-215. 


\section{Conclusion}

The formation of a Chinese immigrant identity in Portland stemmed from many factors. Demographically, merchants governed a predominantly male community. Laborers depended on Chinese merchants for lodging, entertainment, goods and services, and above all labor connections to white employers. Merchants also provided crucial representation and support for laborers and other Chinese in court battles against whites. Merchants' understanding of the U.S. legal system provided a safety net when immigrants were docked pay or held at ports of entry during the early years of Chinese exclusion. Through economic and partial cultural assimilation, Chinese merchants established themselves as elites within the immigrant culture. However, this level of adaptation by merchants did not necessarily translate into religious and cultural assimilation to the American mainstream. While merchants adapted their business practices to the American economy, they, more than nonmerchants Chinese, perpetuated the retention of trans-Pacific relations that kept Chinese immigrants connected to their Chinese families, customs, and language.

On the other hand, immigrants outside the merchant class faced different challenges from both the white and Chinese communities. To many whites, nonmerchant immigrants, especially laborers, were viewed as competitors for jobs and a threat to the domestic moral order. While newspaper reports frequently depicted Chinese immigrants as morally depraved, they seldom attacked Chinese businesses or the Chinese merchant class per se. Instead, they viewed the "Chinese problem" in 
Portland as one rooted in the laboring class. Chinese, and especially non-merchant Chinese, also posed a perceived threat to the white moral code. To overcome this perceived threat, missionaries targeted the majority non-merchant class and encouraged religious assimilation through schooling in the Chinese mission schools. But in turn, those immigrants who embraced assimilation faced severe reprisals from their fellow countrymen who insisted on retaining customs. Pressure to assimilate--as subsequent chapters will show-continued both to unite and divide the immigrant Chinese population as it strove to defuse and develop ethnic autonomy in the United States. 


\title{
Chapter Two
}

\author{
A Division Between: \\ Missionary Influence and Conflict in Portland's Chinese Enclave, \\ $1879-1900$
}

In the Baptist Church's 1875 annual report, a representative commented on the success of the church's missionaries among Chinese in Portland, Oregon. On the Mission School he noted, "To human sight, the project was Utopian; to the eye of faith, a certainty, for the spirit of Him who made the human heart had spoken and His children know that, though China is ten thousand miles across a trackless sea, the Chinaman is a "neighbor.",' Despite this seemingly positive assessment, missionaries in Portland had a combative relationship with the Chinese immigrant community. Those Chinese who attended mission schools and converted to Christianity were praised for their willingness to adopt western morality and lifestyle. On the other hand, missionaries dealt harshly with Chinese immigrants who rejected mission teaching, preaching, and conversion campaigns. Missionaries based their opinion, and justified that opinion, on racialized images of Chinese immigrants as drug addicts, gamblers, and sexual predators.

This chapter looks at how Christian missionaries established and carried out their missions and rescue campaigns in Portland's Chinatown. Through mission schools, street preaching, and legal battles, missionaries sought to alter the moral landscape of the predominantly male Chinese enclave in Portland. More importantly, this chapter shows that Chinese, in the era of social and moral reform that swept the

1 "Annual Report of Chinese Mission School, Portland, Ore., for the Year ending Nov. 13, 1875," Daily Oregonian, Nov. 23, 1875, Oregon Historical Society Collections. 
country from the 1880 s through the turn of the century, were discriminated against in court battles that hinged on the establishment of moral authority. In legal cases that involved financial disputes or violence, Chinese were granted due process rights in keeping with constitutional procedures. However, in cases that involved issues of morality, especially child custody and prostitution, Chinese experienced racism and violation of due process.

Beginning in the 1870s, missionaries established English-language schools that appealed to laboring and merchant Chinese. Most Chinese attended mission schools to learn English, with a few eventually converting to Christianity. Missionaries praised converted Chinese and saw them as a group capable of spreading the Christian faith to China upon their return. Missionaries also began "rescue campaigns" in the 1890s. These campaigns were similar to those in San Francisco that Peggy Pascoe has described in Relations of Rescue. ${ }^{2}$ Rescue campaigns carried out by Portland missionaries took Chinese women and youngsters out of Chinatown to live with missionaries or American hosts. Chinese immigrants did not stand by idly. Instead, they united with one another to retain custody of women and children who, they held, had been seized by benevolent associations. During legal battles, missionaries racialized Chinese using images widespread among the majority white community and ethnocentric notions that highlighted the perceived cultural and moral superiority of western society.

${ }^{2}$ Peggy Pascoe, Relations of Rescue: The Search for Female Moral Authority in the American West, 1874-1939, (Oxford University Press: New York, 1990). For information on Protestant missionaries among the Chinese immigrant community in San Francisco, see Wesley Woo, "Chinese Protestants in the San Francisco Bay Area," in Sucheng Chan, Entry Denied: Exclusion and the Chinese Community in America, 1882-1943 (Temple University Press: Philadelphia, 1991), pp. 145-213. 


\section{Mission Background in Portland}

Missionary influence among Chinese began at least a decade before sweeping numbers of immigrants began arriving in the California gold fields in the $1850 \mathrm{~s}$. By the 1840s, Protestant missions in China were in full swing, although their success was modest to say the least. By 1840 less than one hundred baptisms had occurred within the Protestant mission in China. ${ }^{3}$ As the 1850 s began, missionaries on furlough brought Chinese visitors to the United States and encouraged their direct involvement in mission work among Chinese immigrants that had, by 1852, established Chinatowns throughout the U.S. West. These converted Chinese served as translators and teachers in mission schools in large Chinese communities like San Francisco as well as small Chinese settlements in places such as Portland and Salem, Oregon.

In the earliest years of mission activity in these Chinatowns, missionaries' first interest was the conversion of Chinese to Christianity. They reached this end by opening mission schools that offered free English-language courses to Chinese immigrants. Baptist and Presbyterian churches established homeland mission schools in Portland and Salem, Oregon as early as 1875 . Missions, generally administered by men but operated by women and Chinese converts, openly constructed their schools to encourage the conversion of Chinese immigrants to Christianity. In their 1875 report to the Baptist Church committee, representatives of the Chinese homeland mission reported that the primary object of mission activity in the Portland was for "the conversion of the Chinese" and focused on "doing good to a needy class groping for light." The Presbyterian mission took a more nuanced approach.. In a statement

${ }^{3}$ Daniel Liestman, "To 'Labor for the Conversion of the Heathen Who Came in Our Midst': Protestants and the Chinese in Nineteenth Century America," Winifred E. Weter Faculty Awards Lecture, Seattle Pacific University, April 14, 1994.

${ }^{4}$ Daily Oregonian, Nov. 23, 1875. 
presented to the 1890 Oregon Synod, for example, mission school coordinators highlighted the importance of teaching arithmetic, geography, grammar, and history. They followed by defining the end purpose of work among the Chinese. As Reverends F. G. Strange, S. D. Fulton, and Elder C. Gaddis reported, Some of the Chinese desire to learn English. These can be reached "by baiting the gospel hook with the English alphabet."...Christianity is taught directly or indirectly all the time, and the teachers are cheered by seeing the greater portion of the scholars losing their respect for idols, many openly avowing their disbelief in the superstitions of their countrymen, and some becoming the true followers of Jesus. ${ }^{5}$

Despite the assured tone of this and other early reports of the hope that English-language classes could turn Chinese immigrants away from their traditional religious convictions, home missionaries in Portland were aware of the fact that Chinese immigrants did not come to the United States to adopt western morality and religion. In an 1891 report the Presbyterian Synod noted,

In this country, the great motive with the Chinaman is a desire to make money. To this everything bends, and with it nothing is allowed to interfere. He has not come here for his health, for study, for amusement, much less to get religion, but to get rich. It is hoped that study will aid this. Hence the

\footnotetext{
5 "U.S. Presbyterian Church in the U.S.A. Synods, Oregon Minutes of the Sessions, $1^{\text {st }}-16^{\text {th }}, 1891-1906$," Vol. 1, no. 1, 1891, pp. 8-9, Oregon Historical Society Collections; The 1878 Baptist Mission meeting reported similar approaches to converting Chinese immigrants, via Chinese representatives: "During the summer preaching was conducted by Rev. Dong Gong and the Christian brethren. The numbers attending were large, respectful, and attentive... One result of these street meetings was to educate an intelligent and powerful minority of the heathen Chinese, and to bring them into sympathy with the Christians. Singing Christian songs was found to be one of the best ways of teaching Christian truth." See, Rev. C.H. Mattoon, "Baptist Annals of Oregon, 1844-1900" (2 vols., McMinnville, Ore., 1905), 1: 304.
} 
willingness to go to school. One needs to be careful lest religion too, shall be adopted, because it will pay. ${ }^{6}$

Another report from 1894 reported, with a clear tone of frustration,

We are doing everything we can think of to help the Chinese, and a measure of success attends the efforts. The Usual school has been maintained and regular Sabbath services, Sabbath school and prayer meetings. We have suffered as all work among the Chinese in this country suffers, from removals both to China and to other cities... What is accomplished in this country is not the most important thing. But to send Christian Chinese men and women back to their own country to help their own people, is our aim. That end we see reached every year. ${ }^{7}$

The desire to send Christianized Chinese men and women home to preach Christianity originated decades prior to this testimonial. In fact, in 1875 the Baptists recruited native speakers to preach directly to Chinese in their native language. The Reverend Dong Gong was recruited in the late 1870 s by the church which reported in its minutes,

Street preaching was conducted for some time during the summer by Bro. Dong Gong assisted by several converts. Before the departure of the last ship to China, loaded with Chinese, four hundred were publicly addressed. Thus the disciples of Jesus are endeavoring to obey His command, "Go ye into all the world and preach the gospel to every creature. ${ }^{8}$

6 "U.S. Presbyterian Church in the U.S.A.," 2: 107.

${ }^{7}$ Ibid.

${ }^{8}$ Daily Oregonian, Nov. 23, 1875. In Daniel Liestman's study of Protestant missions in the western United States, he notes that street preaching and conversion activities led by converted Chinese missionaries were rarely viewed positively among the immigrant community. Leistman wrote, "Among the Chinese people too there was opposition to the home mission efforts. Converts faced various degrees of censure, 
Most reports that came out of Presbyterian and Baptist meetings carried an ethnocentric bent. One report from 1875 noted, "A strong and increasing moral and civilizing influence over forty other pupils, the majority of whom have already renounced their idol worship of their ancestors, and are ready to be led to the light." More strongly, missionaries cited the Chinese as a particularly pitiable class, ascribing to them a cultural background that not only allowed vice in the legal sense, but even mandated that vice. Of particular concern was the perceived Chinese propensity for gambling, opium smoking, and prostitution, practices that had developed in China and that immigrants had transplanted to the United States. It was the desire to control and, more importantly, end vice among the Chinese population that encouraged Christian missions to establish schools for Chinese and sponsor street preaching among the immigrant population. ${ }^{10}$

punishment, and ostracism for their decision...Y Yong Gim of Sacramento requested police protection when he preached publicly. Street preaching in Oakland ended with threats against the lives of the Chinese preachers." See, Leistman, "To Labor for the Conversion of the Heathen," pp. 28-29.

${ }^{9}$ Daily Oregonian, Nov. 23, 1875.

${ }^{10}$ For more on traditional Chinese schools for second-generation children see, Timothy J. Stanley, "Schooling, White Supremacy, and the Formation of a Chinese Merchant Public in British Columbia," BC Studies, 107 (1997), 3-28. For more on Chinese prostitution in U.S. West Chinatown's and white American's impressions of Chinese prostitution, see Neil Larry Shumsky, "Americans and Segregated Prostitution," Journal of Social History," (1986), pp. 665-679; Neil Larry Shumsky and Larry M. Springer, "San Francisco's Zone of Prostitution, 1880-1934," Journal of Historical Geography, 7 (1981), pp. 71-89; Ivan Light, "From Vice District to Tourist Attraction: The Moral Career of American Chinatowns, 1880-1940," Pacific Historical Review, 43 (1974), pp. 367-394. 
As Portland's Chinese immigrant population grew through the $1870 \mathrm{~s}$ missionaries reassessed their approach to converting Chinese to Christianity and stamping out vice in the city's Chinatown. In addition to education and street preaching, the Baptist and especially Presbyterian churches established women's home missions. This group was in charge of locating Chinese women who would otherwise be unable, or unlikely, to attend mission schools. In 1873, the Presbyterian Church established the Chinese Woman's Home. The Home was designed to house Chinese women "who are susceptible to kindly influence and desire" in a place where "influence and desire to change their life may be received." The Woman's Missionary Society sought to "rescue" young girls who were in "prospective bondage" and from their male keepers. After rescuing these girls, generally by forcibly taking them from Chinatown, missionaries set up schools where "religious instruction is regularly given both to those living in the Home and to women gathered from outside." In Portland's Chinatown, the Reverend William Holt and his wife Kate were in charge of establishing and carrying out the Presbyterian rescue mission. Under the Presbyterian Church's Portland branch of Home Missions, the Women's North Pacific Presbyterian Board of Missions (WNPPBM) served as the representative for wayward Chinese women and children. The WNPPBM located and took women and children out of houses of prostitution and accepted these groups who came to the Mission for safety. With the help of law enforcement officials and encouragement in the press, the

\footnotetext{
"Joshua Bolles, "Historical Sketches of the Missions among the North American Foreign Missions of the Presbyterian Church" (Philadelphia, 1891), p. 36-40.
} 
WNPPBM succeeded in seizing numerous Chinese women and youngsters. They

fought for legal custody in county courts against Chinese men and women who claimed legal guardianship to the subjects in question. After rescuing women from Portland's (and San Francisco's) Chinatown, the women's missions went to work in instructing "inmates" on "habits of industry" such as sewing and household management. Additionally, daily sessions at the school included religious instruction. $^{12}$

Historian Peggy Pascoe has examined the history of Donaldina Cameron's Presbyterian Mission Home in San Francisco, which resembles closely Portland's Presbyterian mission movement. Founded in 1874, the San Francisco Presbyterian Mission Home for Chinese provided a model for Portland's WNPPBM. Both the San Francisco Presbyterian Mission Home and the WNPPBM saw their "rescue" of Chinese women from houses of prostitution as "skirmishes in a righteous battle against sexual slavery."13 As Pascoe describes, mission rescue stories, which turned into a veritable literary genre during the late nineteenth century, sensationalized

${ }^{12}$ Like Protestant missionaries, Baptist representatives working among the Chinese population in Portland faced both success and failures during their earliest years. One report noted that the "high Christian ground taken in relations to the treatment of Chinese women," in 1877 ended with a "serious secession" in overall membership of Chinese at the Baptist Mission. And another report from 1879 noted the presence of Chinese women who willing sought the aid of the Baptist Mission: "Some questions relative to Chinese women threatened trouble for a time, and caused much anxiety... Three [Chinese] women sought the protection of the mission; after carefully examining each case, two were provided for. The other was shot on the street while attempting the second time to escape from the degrading life she was compelled to lead." See, Mattoon, "Baptist Annals," pp. 304, 306.

${ }^{13}$ Peggy Pascoe, "Gender Systems in Conflict: The Marriage of Mission-Educated Chinese American Women, 1874-1939," Journal of Social History, 4 (1988), pp. 631 668. 
images of Chinese prostitutes and their depraved male Chinese keepers. Rescue stories were accompanied by equally sensational portrayals of illegal Chinese organizations like the so-called tongs that were thought to control the Chinese prostitution trade in the American West. And while missionaries avoided racist stereotyping of the Chinese immigrants who were educated in mission schools, they were more than willing to use racist stereotypes of Chinese immigrant culture in their custody battles with Chinese.

Two types of Chinese custody cases occurred in the 1880 s and 1890s. Some cases, like that of Chan Lon Heung (1883) involved abandoned children and set white rescuers against Chinese immigrants seeking custody of those children. These cases illustrate the relative success that Chinese immigrants had in winning custody cases over Chinese women and youngsters when their cases went unchallenged by whites. ${ }^{14}$ In the case of Chan Lon Heung, for example, Chinese immigrant Chan Bo stated that Chan Lon Heung was fourteen years old and was without parents or other relatives or friends. For some time prior to the case, he stated, he had supported Chan Lon Heung and was willing to assume the education and material support of the youngster if he was awarded custody. Chan Lon Heung also testified that she desired the court's approval of Chan Bo's guardianship and accepted his testimony as true. With the support of Chinese merchants Seid Back and N.W. Gow as sureties (or financial backers), Chan Bo was awarded full custody of Chan Lon Heung on June 5, 1883. ${ }^{15}$ The case of Chan Lon Heung was not unprecedented in Portland. Many

${ }^{14}$ In the matter of the estate of Chan Lon Heung-a minor, Est. 927, June 6, 1883. ${ }^{15}$ Ibid. 
Chinese sought custody of Chinese women and children. Some did so out of concern for their well being. These cases were brought to the county court by concerned friends of families, or families that were unable to care for their children because of poverty and other conditions. Other women and children were claimed by concerned immigrants after they fled the brothels where they were kept as prostitutes. In other cases, Chinese men fought for guardianship rights with the goal of prostituting women in brothels, indenturing them to lives of squalor and abuse. Yet, a third type of custody battle, those in which whites contested Chinese claims, challenged the autonomy of Chinese immigrants who brought their custody requests to the circuit court. In these cases, especially when white missionaries pressed cultural and moral grounds for claiming legal guardianship, the court generally denied custody to Chinese claimants. These cases were marked by racist arguments and popular imagery about the inferior cultural, ethnic, and moral background of Chinese society and immigrant culture.

Two cases exemplify the conflicts-cultural, religious, ethnic - that occurred in these custody battles over Chinese women and children. In the spring of 1889 , the WNPPBM appealed a judgment previously reached by the Multnomah County circuit court. The decision had granted full guardianship of two young sisters, Ah Won, age eight, and Ah Tie, age ten, to Yum Chung, who claimed to be the girls' uncle, and Fung Que, who insisted she was their stepmother. In the original case, the court's grant of custodial rights was based on the testimony of the uncle and stepmother and 
other Chinese witnesses. ${ }^{16}$ And, like the case of Chan Bo, the claimants relationship to the youngsters in their and others' court testimony was undisputed, until, that is, missionaries heard of the case and seized the youngsters from the house of Fung Que, claiming they were housed in ill-conditions and in need of protection. In June 1889, the WNPPBM filed a petition, under the Abused and Neglected Children's Act (enacted in February 1889 by the Oregon legislature), for the arrest and surrender of the two Chinese children. ${ }^{17}$ Under the same benevolent charities act, the Boys and Girls Aid Society (BAGAS), a local charitable organization founded in 1885, jointly amended the petition and the court awarded custody of the children jointly to the WNPPBM and BAGAS.

In their original petition, the two charitable organizations based their claim to custody on their "strong suspicion" that the girls were being housed, not in the custody of caring Chinese relatives but, rather, in a "house of ill-repute." They charged that Fung Que "was a woman of notoriously bad character" and that the children "were being trained to lives of immorality and vice, and unless removed from said evil

${ }^{16}$ In re North Pacific Presbyterian Board of Missions v. Ah Won and Ah Tie, Oregon Reports, Jan. 1890, pp. 339-350. (hereafter NPPBM v. Ah Won and Ah Tie).

${ }^{17}$ See "An Act to confer certain powers upon certain benevolent or charitable corporations, incorporated under the laws of Oregon, in relation to the control and disposition of homeless, neglected, or abused children," in WNPPMB v. Ah Won and Ah Tie, pp. 339. The Boys and Girls Aid Society (BAGAS) was a secular organization established to house abused and neglected children, some of whom were taken by the state of Oregon and placed in the home and others who were placed in the home by parents unable to care for their own children. Because the names of the youngsters in this case were not found in the BAGAS "list of wards," it can be assumed that the BAGAS filed a petition jointly but provided only temporary living quarters. Officially, according to the court decision, custody of Ah Won and Ah Tie fell on the NPPBM. 
guardianship and influence would almost inevitably become prostitutes and

criminals." ${ }^{18}$ On these grounds, the two organizations, citing the Benevolent Charities Act, asked the court to transfer the children to the temporary care of the BAGAS, until full custody could be arranged at the women's mission home.

In response a cross petition was filed by yet another Chinese immigrant, Wong Chin Way, who claimed to be the guardian of the two youngsters and their estates and the brother of deceased father, Wong Sing and brother-in-law of the deceased mother, Hing Toy. In his petition, Wong Chin Way denied the accusations against Fung Que and Yum Chung. He alleged that the relationship of Yum Chung existed in fact and that, if the children were taken from their relatives and guardian and given to the mission society, the missionaries would attempt to entice them from the religion of their father and mother and relatives still living. ${ }^{19}$ Wong Chin Way added that, if the court upheld his petition for guardianship, he intended to send Fung Que and the children to live with their grandmother in southern China. ${ }^{20}$ After further deliberation, the circuit court judge awarded the BAGAS temporary custody of the children until appeals on both sides were resolved. ${ }^{21}$

${ }^{18}$ In re North Pacific Presbyterian Board of Missions v. Ah Won and Ah Tie, Oregon Reports, Jan. 1890, p. 340. (hereafter NPPBM v. Ah Won and Ah Tie)

${ }^{19}$ Ibid.

${ }^{20}$ Wong Chin Way's petition was supported by fellow Chinese immigrants, Wong Mon, Oak, and Wong King Chick. In an unrelated trial in 1893, Mon Oak was indicted for smuggling opium through a West Coast criminal network. Mon Oak was listed as "medicine man" and "opium merchant" in the 1890 Polk's Directory for Portland.

${ }^{21}$ Review of archival materials housed at the headquarters of the Boys and Girls Aid Society in Portland, Oregon, it appears that the BAGAS served only as a temporary housing station for Chinese children seized by missionaries. Only three Chinese 
In their first petition, the benevolent organizations cited both the poor living conditions of the children and the bad character of the uncle and stepmother as primary reasons for their custody request. The two groups freely wielded racist stereotypes to support their claims. During the second appeals stage, in July 1889 , missionaries reemphasized racial stereotypes in their claims. As this trial began, Wong Chin Way's testimony, and the opposing arguments of the missionaries, developed into a battle for moral authority. At face value, the debate between the Chinese and white petitioners was over the living conditions of the children and the opportunities they possessed for education and material advantage. Underneath this debate however, was a more elaborate, and loaded, issue. The fight for moral authority was hashed out over a two-day period with Wong Chin Way beginning the debate during the first day of the trial.

Responding to missionary claims that, unless the children were "removed from said evil guardianship and influence" they would "almost inevitable become prostitutes and criminals, Wong Chin Way argued that, in fact, "if the children were taken from their relatives and said guardian and given to the said petitioners [the WNPPBM and BAGAS] they would attempt to entice them from the religion of their father and mother and their relatives now living."22 Wong Chin Way established, further, that he was a man of sufficient means and standing in the community and was

names are listed in BAGAS records and these date from the twentieth century. From the lack of permanent Chinese residents at the BAGAS we can assume that mission homes were the final destination for immigrant women and children removed from Chinatown.

${ }^{22}$ WNPPBM vs. Ah Won and Ah Tie, p. 343. 
able to care for the youngsters along with their existing Chinese relatives. He highlighted the importance of the children being raised in a home where custom, language, and culture were cultivated, and he emphasized the goal of the children's eventual return to their grandmother's home in China.

After hearing the testimony of the missionaries and of Wong Chin Way, the court again ruled that the children remain in the temporary custody of the BAGAS. In October 1889, however, Wong Chin Way filed a third petition stating the ship Coloma would sail from Portland to China on October 15, 1889. The Captain of that vessel, Cyrus Noyes, was cited as duly able to see that the girls reached their grandmother's home safely if the court allowed for their travel. Wong chin Way again stated that the children's' "surroundings and teaching" at the BAGAS "were contrary to that of their parents." Because of that, claiming to speak for the family, he asked the court to permit the children's' return to China aboard the Coloma. In their counter petition, the BAGAS stated that Wong Chin Way's petition was nothing more than a desire to "obtain possession of them [Ah Won and Ah Tie] and remove them from the custody and possession of said society, so that they might be kept as property and trained up for dissolute and immoral lives." ${ }^{23}$ On October 15 , the court ruled that the children be turned over to Captain Cyrus Noyes to travel to Hong Kong. They were to be delivered to their relatives and taken to their grandmother at Chow Bow. But the case was not over. Again, the BAGAS filed a petition against the shipment of the children, and this one was accepted by the court, which-without explanation-ordered that the

${ }^{23}$ Ibid., p. 343. 
children be placed in the care of the BAGAS until further notice.

This final petition was particularly revealing because of the racist stereotyping employed by the missionaries--and its apparent embrace by the court. In his closing statement, Judge C.J. Thayer declared,

The purpose of the [Benevolent] Act is to secure to homeless, neglected or abused children nurture and support during their tender years, and such an education and training as will give them a fair start upon the journey of life. Its aim is to develop whatever good qualities they may possess and thereby restrain the bad ones, in order that they may ultimately become useful to society, instead of being a pest. The establishment of the Boys' and Girls' Aid Society was intended... for a humane and practical object, designed to alleviate misery and suffering and to promote the welfare of the community. ${ }^{24}$

Judge Thayer went on to praise the BAGAS and WNPPBM, contending that "The high standing and reputation in the community of those having charge of the institution insures confidence... and we may properly assume that if those children are allowed to remain under its control and influence, their mental, moral and physical condition will be greatly improved." 25 In the missionaries' and judge's minds, the "welfare of the community" quite clearly referred to the moral code of the majority white population, a moral code symbolized by the WNPPBM and BAGAS. Even more explicitly racist rhetoric tainted Judge Thayer's closing remarks: "The Chinamen such as we have among us can rarely be trusted" and they generally exhibit "a total disregard of virtue, candor and integrity, and have shown such a propensity to cunning, deception and perfidy, that if they were to engage in an effort to accomplish

\footnotetext{
${ }^{24}$ Ibid.

${ }^{25}$ Ibid., pp. 348-349.
} 
an apparently meritorious object a strong suspicion would arise that there was some covert, sinister scheme at the bottom of it." ${ }^{, 26}$ Falling in line with the arguments of the missionaries, Thayer went on to declare that "our societies of to-day, whether in the church or out of it, are seldom engaged in any narrow sectarian schemes, but are endeavoring to elevate and improve the moral and physical condition of the lower strata of humanity, in order to enable that class to secure more substantial happiness." ${ }^{27}$ In closing Thayer claimed, "something more is now required of mankind than a blind adherence to bigotry," and those men and women who engage in benevolent work,

who search in the dregs and scum of society, and find suffering and abused children, and relieve their wants and necessities, and train them in the path of rectitude, with a view to rendering them useful in the world, instead of being a burden and a nuisance, are fit and proper to be the guardians of any child, whether of Christian or pagan extraction. ${ }^{28}$

In its final ruling, the court granted full custody to the WNPPBM, with the BAGAS serving as temporary ward. The court ruled that "a strong suspicion existed of a design to sell the children for immoral purposes," even though no direct evidence had ever been submitted to support such a claim. ${ }^{29}$

Throughout the 1890 s, missionaries allied with benevolent organizations, law enforcement officials, and sympathetic lawyers, continued to claim guardianship of Chinese children. Similar to missions in San Francisco and elsewhere, alleged

\footnotetext{
${ }^{26}$ Ibid.

${ }^{27}$ Ibid.

${ }^{28}$ Ibid., p. 349.

${ }^{29}$ Ibid.
} 
prostitutes and so-called "wayward" children were placed in the care of religious institutions and secular institutions like the BAGAS. Once in protective homes, women and children served as seamstresses for pastors or as live-ins who held jobs familiar to late-Victorian era women. Chinese were clothed in high-necked, anklelength dresses, wore bows in their brushed, braided hair, and learned to play musical instruments, sew, and keep house. Education was conducted throughout the day with various teachers, usually women like Kate Holt, who ran the Chinese Mission Home. All along, the home worked in conjunction with groups that shared the mission's goals, such as the attorney Thomas Strong, who regularly represented missionary organizations in court.

At the same time, male Chinese immigrants grew increasingly adamant in contesting these benevolent groups' custody of Chinese women and children. They supported one another financially and through testimony in court. As missionaries attacked the integrity of immigrant culture and Chinese religion, familial norms, and language, immigrants, it appears in the sheer bulk of cases, resolved to fight for custody. The case of Suie Yea is a case in point.

In July 1892 an established Chinese merchant, Louis Won, applied for and received guardianship of Suie Yea. ${ }^{30}$ As in the case of Chan Bo, Louis Won testified that Ei Nayn, the mother of the young girl, had, before she died in San Francisco in 1887, placed Suie Yea in his custody. He demonstrated that he had for some time maintained the child's daily welfare and education and wished legally to become her

${ }^{30}$ In the matter of the Guardianship of Suie Yea, a minor, Est. 2331, Multnomah County Court, Aug. 9, 1892 (hereafter Suie Yea). 
guardian. After the court reviewed Louis Won's testimony, he was in fact granted full custodial rights. The case remained closed for three months, but in October of 1892 , Jennie P. Martin, head matron of the Chinese Refuge Home, filed a petition on a writ of habeas corpus for the annulment of guardianship rights previously granted to Louis Won. According to Martin, fourteen-year old Suie Yea had, since May 1892, lived at the Chinese Refuge Home, and it was only after Louis Won approached the Refuge Home and demanded custody and possession of the girl that she was removed from the house. ${ }^{31}$ Martin defended the three-month gap in her filing of an annulment petition on the grounds that no notice of Louis Won's petition of guardianship had been shown to her and that the pending petition had not been revealed to the Chinese Refuge Home or its representatives.

Martin sought to establish the claim of the Refuge Home and her petition for guardianship of Suie Yea in a number of ways. She stated that the Home was a benevolent corporation formed and existing under the laws of Oregon with the object and purpose of serving as a refuge home for Chinese girls and women. According to Martin, fourteen-year old Suie Yea had approached the Refuge Home of her own free will and convinced a representative of the Home that she was an orphan. Contrary to the claims of Louis Won, Martin testified that, to her knowledge, Suie Yea's father was still alive although no information could be provided about him. Martin made special note, in this as well as future petitions, that Suie Yea "stated that her reason for leaving her Chinese home was that she was beaten and abused and directed to wash

${ }^{31}$ In her testimony, Jennie Martin referred to the youngster as Fong Lang or Chy Lun. 
the naked bodies of men, and that she would rather die than submit to such indignities." 32 From that time on, Martin testified, the child had been sheltered at the Refuge Home with the Lady Managers acting in loco parentis. In their assessment, the Lady Managers concluded that the child "is an intelligent capable child, well able to make an intelligent choice as to who should be appointed her guardian or as to where she should reside." 33

Martin included in her petition descriptions of Chinese immigrant culture popular in mainstream stereotypes. After declaring that "Louis Won is not a person of good moral character," Martin denied that Louis Won had ever been asked by the mother of Suie Yea to serve as guardian. Instead, she claimed that Louis Won had purchased Suie Yea, about five years earlier, from a procuress in San Francisco for $\$ 460 .^{34}$ The child, Martin stated, was held by Louis Won as a slave with the intent of either making her a domestic servant or selling her to a Chinese brothel. Finally, and in racially loaded terms, Martin stated that Louis Won was a married man with four children, all of whom lived in China. In the United States, Martin declared, Louis Won lived in Portland with a woman who was not his wife but, rather, his concubine. Images of concubines and their Chinese overlords were a familiar symbol in popular magazines like Harpers and West Shore. Concubinage in China was generally reserved for the elite class; merchants and laborers normally lacked the means to

${ }^{32}$ Ibid. It is not clear, when Martin referred to Suie Yea's "Chinese home," whether she meant the home of her father from which she was orphaned or the home of Louis Won, Suie Yea.

${ }^{33}$ Ibid.

${ }^{34}$ No evidence was ever submitted by Martin to validate these claims. 
support concubines and neither did Chinese immigrants living in the American West. These charges were a useful tool for Martin, however, in making her case against Louis Won's guardianship rights. And the judge agreed. After considering Martin's petition, he ordered Suie Yea to enter her own opinion in court as to who would best serve as her legal guardian.

On October 10,1892, Louis Won presented his response to the county court. He supplied a striking denial of the charges against him. He began by denying the Suie Yea had voluntarily gone to the Chinese Refuge Home or that he had beaten, abused, or directed her to wash the bodies of naked men. He further denied that the Lady Managers of the Home had ever acted in loco parentis to the child, and he restated that Ei Nayn was, in fact, her mother. Finally, he denied that he had purchased the youngster or that she was being kept in a house of prostitution. Drawing on corroboration from other witnesses who testified in his behalf, Louis Won chastised the missionaries for their racist accusations. He concluded by defending the legality of both his marriage to a second wife, which was, in fact, common among Chinese immigrants in the United States, and the living arrangements he had established with his second wife in Portland. He testified that, "the woman with whom [he] lives is not his...concubine...but that he is married to said woman with whom he now lives in the City in accordance of the Chinese Laws and Customs." He attacked directly the claims of the missionaries by stating that he had no proof, nor had the Refuge Home provided any proof, that it was able to provide a nurturing environment, proper education, or "proper position and station in life for the youngster 
any better than could he.",35

Along with his defiant denial of the accusations against him, Louis Won subpoenaed prominent Chinese and white character witnesses to testify in his behalf. ${ }^{36}$ Among them were Seid Back, the well-known merchant who had earlier testified in favor of guardianship rights in the case of Chan Bo, and a prominent white executive of the U.S. Electric and Lighting and Power Company, Leander L. Hawkins. These men not only supported the testimony of Louis Won but also agreed to serve as sureties in all trials before and after the response phase. But to no avail. In their closing remarks, representatives from the Refuge Home declared their ability to

maintain and keep her as a Chinese child and woman under the best influences, and will carefully nurture and educate her for her proper position and station in life, and, when she becomes of legal age, will look carefully after her, and, so far as they can, will see that she is well married or otherwise provided for in life."

Guardianship granted in the first phase of the trial was annulled, and young Suie Yea went to live in the Refuge Home until she reached the age of majority. ${ }^{38}$

Despite the assistance of well-known Chinese and whites, and his own documentation of his ability to support Suie Yea, the court ruled, without comment, in favor of Jennie Martin and the Chinese Refuge Home.

${ }^{35}$ Suie Yea, p. 29.

${ }^{36}$ Among those subpoenaed were D.M. Dunny, John Kelly, L.L. Hawkins, George L. Story, and Seid Back. Hawkins and Back were partners in a shipping company that traded goods between China and the United States. John Kelly garnered fame in Oregon after serving in the illegal smuggling of laborers onto ships in Portland. Ibid. ${ }^{37}$ Suie Yea, Est. 2331, appellate trial, p. 4.

${ }^{38}$ Ibid. 


\section{Conclusion}

The guardianship cases of Chan Lon Heung, Ah Won and Ah Tie, and Suie

Yea have a number of implications. In each case, Chinese petitioners submitted guardianship bonds that proved their financial ability to provide for the youngsters. In the cases of Chan Lon Heung, Chinese and white witnesses testified on behalf of Chinese petitioners and provided financial assistance necessary to bring the case to trial. And while Chan Bo succeeded in his case, Wong Chin Way, in the Ah Won and Ah Tie case, and Louis Won, in the case of Suie Yea, both failed. Their documentary evidence, testimony, and white as well as Chinese witnesses failed to outweigh the racist and ethnocentric testimony of white missionaries - all of which was readily accepted and supported by judges, especially in the case of Ah Wa and Ah Tie.

These three cases also represent how anti-Chinese racism remained strong through the nineteenth century and into the twentieth century. Even after passage of Chinese exclusion laws banning the arrival of laborers in the United States, whites sought domination over the immigrant Chinese culture. Missionaries saw their rescue campaigns in Chinatowns as battles with evil. They justified their missions by citing the moral threat the immigrant culture posed to the majority white public. In court, missionaries cited the inherent racial and cultural inferiority of Chinese immigrants and the larger Chinese society. And while missionaries could put aside their racist rhetoric when teaching Chinese men in mission schools, they were unwilling to set it aside in court battles over women and children. Missionaries saw Chinese guardians as purveyors of immorality that would inevitably be inserted into the souls of women 
and children under their control. They fought their moral battles in an effort to protect the young and women from this inevitability. In the end, many Chinese women and children were placed under the protection of mission homes by the courts. Of these wards, many were eventually to marry to converted Chinese men whom missionaries approved. Others remained in the homes of missionaries as teachers and house women.

Missionary influence in Chinatown and the division between white and Chinese moral superiority that played out in courts was only one aspect of whiteChinese interaction. As the era of Chinese immigrant exclusion took root beginning in the 1880 s, situations arose that allowed Chinese and whites to breach the cultural barriers that had, for decades, set the two cultures off against one another. In one telling example, the subject of Chapter Three, Chinese and whites collaborated closely-and illegally - turning profits off extensive West Coast immigration and opium smuggling operations. 


\section{Chapter Three}

Border Crossings:

Race and Illegal Immigration in Portland and British Columbia

In December 1893, the District Attorney for the State of Oregon indicted twenty-eight men in the United States District Court. In October of the same year, a 450-pound shipment of opium was loaded aboard the steamer Wilmington in Vancouver, British Columbia. Suspicious of the shipment, a Vancouver customs agent telegraphed ahead to the Astoria, Oregon, customs house, located at the mouth of the Columbia River-the main waterway into the city of Portland. Working on a tip, the owners of the Wilmington headed downriver to retrieve the ship and dump its illicit contents. But customs agents had already apprehended the shipment.' Then began one of the largest nineteenth-century opium and immigration smuggling cases on the West Coast. Of the Portland-British Columbia operation, one San Francisco newspaper declared, "the [smuggling] has been carried to an extent and audacity little short of marvelous."2

The men indicted, both white and Chinese, were charged variously with smuggling and concealing opium and aiding and abetting the landing of illegal

\footnotetext{
${ }^{1}$ Approximately 450 pounds of opium was put on board the Wilmington at Vancouver, British Columbia. In court testimony, witnesses stated that William Dunbar, one of the men indicted in U.S. v. Wilson found out about the telegraph and sent two partners to Astoria to go out in a plunger (a small boat), meet the steamer, and tell the engineer to burn the opium. They failed to do this, as a revenue cutter was nearby, and the opium was seized. Another 500 pounds of opium was, however, successfully landed a few days later.

${ }^{2}$ Daily Oregonian, Dec. 11, 1893.
} 
Chinese immigrants in the United States. ${ }^{3}$ In the thirteen months before their arrest, the indictment charged, Nathan Blum, William Dunbar, P.J. Bannon, and Glen O.

Holman had conspired with Port of Portland customs officials to land illegal immigrants from China via ports in British Columbia. With the assistance of a Victoria, British Columbia, co-conspirator, Major John Wilson, the smuggling operation had quickly expanded to include an extensive network of powerful Chinese opium distributors, merchants, and legal and political representatives in both British Columbia and Oregon. ${ }^{4}$

As the trial would reveal, the illicit trade in human cargoes after the 1882 Chinese Exclusion Act had penetrated seemingly impermeable racial barriers that divided the general Chinese and white communities. White and Chinese coconspirators set aside racial assumptions about one another to turn profits off of immigrant exclusion and demand for opium in, and beyond, West Coast Chinatowns. Chinese merchants, it appeared, possessed power not only within their own communities but within the larger, white-dominated economy as well. And, in the

${ }^{3}$ The original case of United States v. John Wilson, Record Group 21, Folder 3875, Parts I, II, III, National Archives-Pacific Alaska Region (hereafter U.S. v. Wilson, File 3875, RG 21, NARA) took place over a period of 18 days and returned 33 indictments involving 58 different persons. The appeal cases of various people indicted in the original case dragged on for more than two years.

${ }^{4}$ U.S. v. Wilson, File 3875 , RG 21 , NARA. The grand jury reported seven indictments as true bills. The only one of these had anything to do with smuggling was one charging William Dunbar, E.P. Thompson, Nat Blum, Seid Back, Ching Chong Quie, and Chuck Kee with smuggling opium on six counts. Alleged to have been operating between the months of March and June 1892, the opium and immigration smuggling ring clearly functioned for much longer. Letters attest to the operations continuance for more than two years, and over that period, over 3,000 pounds of opium was confiscated on the steamers owned by the Blum-Wilson syndicate. See, Daily Oregonian, Dec. 10, 1893. 
end, the trial revealed how common immigrants were reduced to the position of a simple commodity while Chinese merchants gained economic power in the white and Chinese communities. The social hierarchy within Chinatown, which placed merchants at the top of the social ladder, is clear.

The Chinese immigration history that preceded the case of U.S. v. Wilson sets the stage for what, during the 1890 s, constituted extensive smuggling networks up and down the West coast. Beginning after passage of the 1882 Chinese Exclusion Act, illegal Chinese immigration through Canada became a veritable racket for those whites and Chinese who had the resources to set up and conceal the international smuggling operations. Historian Erika Lee, in her comparative study of illegal Chinese immigration along the Canada and Mexico borders, has documented the means by which smugglers brought Chinese to the United States. She shows that the racialization of Chinese immigrants in the decades leading up to the 1882 Chinese Exclusion Act encouraged Chinese to adopt the racial identity of Native Americans and Mexican laborers as they crossed the two borders into the United States. Furthermore, according to Lee, the varying anti-Chinese laws in the three countries actually encouraged illegal immigration by forcing it underground. ${ }^{5}$ This chapter affirms that anti-Chinese immigration laws did in fact encourage illicit trade in

${ }^{5}$ Erika Lee, "Chinese Exclusion at the Borders with Canada and Mexico," Journal of American History, (2002), pp. 54-86. Other historians who have studied illegal immigration include Roland L. De Lorme, "The United States Bureau of Customs and Smuggling on Puget Sound, 1851-1913," Prologue, 5 (Summer 1973), pp. 77-88; Hung-chan Kim and Richard W. Markov, "The Chinese Exclusion Laws and Smuggling Chinese into Whatcom County, Washington, 1890-1900," Annals of the Chinese Historical Society of the Pacific Northwest (1983), pp. 16-30. 
immigrants and opium into the United States. Further, anti-Chinese immigration laws encouraged collaboration between Chinese merchants, laborers, and whites to master illegal immigration and opium smuggling across the Canadian-United States. Illegal immigration operations linking British Columbia to Portland were very much multiracial enterprises. Thus, on the one hand, large scale smuggling of illegal immigrants displays the breaching of racial barriers betweens whites and Chinese while, at the same time, it reinforced the merchant-dominated class hierarchy that had developed within the growing Chinatowns of both Portland and Vancouver.

\section{Chinese Exclusion Laws and the "Smugglers Paradise" of British Columbia}

At the time of the 1882 Chinese Exclusion Act, anti-Chinese sentiment in the United States was especially strong among labor leaders and anti-assimilationists. After years of anti-Chinese sensationalism in the press, the public at large possessed a ready-made image of the Chinese as the "yellow intruder" who had come to the United States to exploit jobs, white women, and other opportunities for vice. Magazines like Harpers Weekly and the San Francisco Wasp highlighted the "Chinese problem" in their pages and often included cartoons depicting Chinese as either “cunning criminals or 'coolies' whose immigration constituted a harmful invasion of inferior and inassimilable aliens." These cartoons, along with heated editorials from common citizens, labor union leaders, and state and national politicians, increased anti-Chinese sentiment among the American public. When the 1879 Fifteen Passenger

${ }^{6}$ Lee, "Chinese Exclusion at the Borders with Canada and Mexico," pp. 63-68. 
Bill (that intended to limit Chinese immigration to fifteen passengers a ship) failed to pass, the cry for stringent exclusion measures only increased. The Chinese Exclusion Act of 1882 satisfied these demands; it excluded all Chinese immigrants from entering the United States who were not merchants, students, visitors, spouses of Chinese merchants already in the country, or diplomats. ${ }^{7}$

While the Exclusion Act satisfied many it did not effectively end Chinese immigration to the United States. The reasons were twofold. First, after the passage of the Exclusion Act, Chinese devised new mechanisms to enter the nation illegally through the porous Canadian and Mexico borders. In comparison to the United States, anti-Chinese restrictions in Canada and Mexico were moderate. Canada's 1885 Chinese Immigration Act imposed a fifty-dollar head tax to be collected by each ship captain at the point of departure, but it still allowed Chinese to enter the country so long as they paid the head tax. ${ }^{8}$ Once in Canada, slipping into the United States

\footnotetext{
${ }^{7}$ For more on anti-Chinese laws passed prior to the 1882 Exclusion Act See, George Anthony Peffer, "Forbidden Families: Emigration Experiences of Chinese Women Under the Page Law, 1875-1882," Journal of American Ethnic History, (1986), pp. 28-46; Bill Ong Hing, Making and Remaking Asian America Through Immigration Policy, 1850-1900 (Stanford, Calif.: Stanford University Press, 1993). The Geary Act, passed in May, 1892, continued the 1882 Chinese Exclusion Law for an additional ten years. Chinese laborers already in the United States were required to apply to the collector of internal revenue within one year after the passage of the act, for a certificate of residence. Those who failed to comply faced arrest and deportation. While stringent in written terms, customs agents were often ill equipped to enforce the laws. In a December, 1893, Daily Oregonian article, a collector at Portland reported that his office had received no official notification of the extension, nor had he been provided any information as to what type of action was to be taken when immigrants failed to register at the internal revenue service. See the Daily Oregonian, Dec. 1, 1893.

${ }^{8}$ U.S. newspapers frequently complained about lax Canadian laws regarding immigration. The West Shore, for instance, reported, "Chinamen are compelled to pay 
required only a short walk or boat ride; in fact, most Chinese simply walked across the border into the United States. ${ }^{9}$ Mexico created another back door into the United States. During the first years following the U.S. Exclusion Act, both Mexican and Chinese officials encouraged Chinese immigration to Mexico. In fact, when China and Mexico signed the 1899 Treaty of Amity and Commerce, Chinese immigration to Mexico increased, and the ability of Mexico to control illegal entry into the United States decreased. ${ }^{10}$

a head tax of fifty dollars to land in British Columbia, and they cheerfully pay this in order to secure a foothold from which they may gain the coveted entrance to the United States, to secure which they would willingly pay many times that amount if they could come direct. By this arrangement Canada gets the money and we get the Chinamen," The West Shore, March 14, 1891.

${ }^{9}$ On the demand of U.S. officials, the Canadian government agreed to tighten their anti-Chinese laws to mirror more closely those of the United States. The Canadian Pacific Railroad Company (CPR) was at first reluctant to adopt the new measures for fear that they would ruin that company's profitable trans-Pacific steamship business. However, in 1903 the CPR complied with two major stipulations tied to the tightened regulations. First, they agreed to examine all Chinese persons traveling on its steamships to determine, as best they could, that United States-bound passengers claiming to be admissible were in fact entitled to enter under U.S. law. Second, the company agreed to deliver all Chinese passengers seeking admission into the U.S. under guard directly to U.S. inspectors stationed at four designated ports along the Canadian border. In 1903, anti-Chinese sentiment and pressure from U.S. Bureau of Immigration and Department of Justice officials motivated Canada to increase its head tax on Chinese immigrants from $\$ 100$ to $\$ 500$. The increased head tax provide a strong deterrent to potential Chinese border crossers. In 1912 Canada also agreed to end the practice of admitting Chinese immigrants into the country if they had already been denied entry into the U.S. Finally, in 1923, Canada implemented the 1923 Exclusion Act that completely abolished the head tax system and instead prohibited all people of Chinese origin or descent from entering Canada. Consular officials, children born in Canada, merchants, and students were exempted. See Lee, "Chinese Exclusion at the Borders with Canada and Mexico," pp. 76-78.

${ }^{10}$ The West Shore reported, "It is impossible to say how many Chinamen succeed in crossing the boundary line from Canada or Mexico and losing their identity [in?] the common monotony of some Chinese colony. It is certain that hundreds crossed in from Mexico... The Canadian border is the one now offering the easiest openings for 
As U.S. officials struggled to tighten barriers against admission, ports of entry became heavily fortified, especially San Francisco and Seattle. They could not, however, control the many loopholes that allowed smugglers entry to the United States with human cargo and opium shipments. Referred to as a "smuggler's paradise," the Puget Sound-British Columbia region offered smugglers a multitude of opportunities to conduct illicit trade undetected. An 1891 West Shore magazine article reported,

The numerous islands in Puget [S]ound at the head of the Straits of Fuca...offer special facilities for the operations of smugglers, who, using small sailing vessels and taking advantage of dark nights and their knowledge of the movements of the revenue officers, have little difficulty in crossing the line with cargoes of opium and its smokers, landing both in the hidden recesses of some American Chinatown."

At major ports of entry, including Portland and other, smaller ports throughout the Puget Sound-British Columbia region, customs agents' inspection of ships became increasingly difficult. A lack of resources and trained customs inspectors increased the burden of inspecting incoming ships and their contents. Furthermore, corrupt judges,

the guileless Mongolian," The West Shore, March 14, 1891. For more on United States-Mexico border enforcement and problems see, Lee, "Chinese Exclusion at the Borders," pp. 58-60.

${ }^{11}$ The West Shore, March 14, 1891. It was not uncommon for smugglers to use fishing vessels to move illegal immigrants from initial points of contact, such as small islands in the Puget Sound, to final points of departure aboard larger steam ships that docked outside of the ports' jurisdiction. To divert attention from their activities, smugglers often repainted both fishing vessels and steam ships and changed the names of ships to confuse observant customs officials. 
customs inspectors, and ship-owners increased the opportunities for Chinese immigrants to conspire with whites and evade exclusion laws.

The case of U.S. v. Wilson displays the loopholes and corruption that followed Chinese exclusion between 1882 and the turn of the century. It allows a reconstruction of just how illegal immigration networks functioned during the early exclusion era and how white and Chinese merchants collaborated in producing an elaborate system of illegal immigration from Canada to the United States. Together, across the racial divide, white and Chinese merchants turned the misfortune of Chinese immigrants into a lucrative business.

The establishment of illegal immigration networks

Beginning in March 1892, Nathan Blum, William Dunbar, and E.P. Thompson, co-owners and operators of the Merchant's Steamship Company (MSC), entered into an agreement with the Canadian Pacific Railroad (CPR) to bring that company's Chinese laborers to British Columbia and transport Chinese railroad workers, stranded in Canada, back into the United States. Like many early illegal immigration networks, companies like the Merchant's Steamship Company operated smuggling operations alongside legal businesses. In the case of the MSC, the new business involved the transport of passengers and agricultural goods between Portland and British Columbia. Shipments of produce, flour, and livestock from Eastern Oregon made up early shipments by the MSC. These operations facilitated the 
development of the MSC's illegal dealings with the CPR. ${ }^{12}$ In their first venture with the CPR in the early 1890 s, the MSC collaborated with railroad officials to carry Chinese passengers from Vancouver, British Columbia, to Portland at the cost of $\$ 6$ a head. ${ }^{13}$ As demand increased, the MSC owners saw the opportunity to raise their rates for Chinese immigrants and did so to the tune of $\$ 10$ a head in 1891 . The railroad and steamship companies continued to operate their immigrant smuggling business at that rate until the Merchant's Steamship Company found new ventures that turned even larger profits later that year.

By May of 1892, Blum, Dunbar, and Thompson realized that the potential profits from illegal immigration extended far beyond their initial arrangement with the CPR. They turned to Chinese merchants in Portland and Vancouver, realizing that they could increase their profits by combining their already established shipping enterprises with a system of immigrant transportation and opium distribution between the Chinese communities in the Puget Sound-British Columbia region and Portland, and, eventually, as far away as San Francisco. Prior to 1892, networks to smuggle opium and other contraband across the United States-Canada border did exist, based upon relationships between Chinese and whites. And while opium was not illegal in the United States until 1906, surcharges tallied at customs checkpoints diminished the

${ }^{12}$ The Canadian Pacific Railroad ran parallel to the U.S.-Canada border from the Pacific Ocean to Lake Superior. A report on illegal Chinese border crossing along the $\mathrm{CPR}$ route noted, "there are many places along the route where a crossing can be made by a person willing to spend the time and money necessary to effect it. But it is the Puget [S]ound where this illegitimate business has become a science." See, Ibid. ${ }^{13}$ The rate for transport of passengers was actually settled at $\$ 7$ a head. See U.S. v. Wilson, File 3875, RG 21, NARA. 
net profit accrued from legal shipments. By smuggling opium, coordinators of the illicit trade shipped many hundreds of pounds of opium from British Columbia to Portland, and even San Francisco, but did not pay taxes on the shipments. Profits on large shipments of opium often totaled in the many hundreds of dollars. ${ }^{14}$

During testimony in U.S. v. Wilson, co-conspirator Nathan Blum described the development of an intricate immigrant-opium smuggling network that joined the Merchant's Steamship Company to Chinese opium manufacturers in Vancouver and Victoria. He and his partners "concluded that we wanted to handle all the China business [opium and immigrants] and we got together and saw where we could form a little trust or monopoly." 15 The men raised immigration rates to $\$ 50$ a head for travel aboard their two vessels, the Haytian Republic and Wilmington, and brought a Canadian, Major John Wilson, into the scheme. Prior to their illegal ventures, Major Wilson had served as agent for three companies-the Merchant's Steamship Company, the Oregon Flouring Mill, and Dunbar Produce and Grocery Company. His charge was to oversee all shipments of goods arriving in Vancouver aboard the two ships. Additionally, and to their advantage, Wilson had close ties to three of the largest opium manufacturers in Vancouver and Victoria. Finally, the operation of these illegal networks between the United States and Canada was not limited to whites. Ching Chong Quie and other large Vancouver opium manufacturers joined the

${ }^{14}$ For instance, in June 1892 Nathan Blum and William Dunbar bought and shipped 365 pounds of opium purchased in Victoria, British Columbia, to Portland. The men purchased the opium for $\$ 2,592.50$ and sold the shipment to Portland opium distributors for $\$ 3,976.25$, thereby turning a net profit of $\$ 1,383.75$, or 53 percent. See, Ibid. . ${ }^{15}$ Ibid.. 
agreement, hoping to increase their own profits in opium manufacturing by fusing this with traffic in illegal immigration.

\section{Crossing Borders}

The lines that divided whites and Chinese were multifaceted during the era of exclusion. Racism and cultural differences marked significant divisions between the two. For decades, Chinese were chastised for their geographic isolation within western American Chinatowns and for their ostensible unwillingness to assimilate to mainstream American culture. Whites also (and ironically) criticized Chinese for their diligent work ethic, particularly in the case of Chinese laborers, whom many whites, especially working-class unionists, viewed as a competitive force in the uncertain job market of the industrializing West. ${ }^{16}$ Racially, whites attacked Chinese as an inferior group, with origins rooted in a backward and heathen culture. And immigrants' unwillingness to assimilate was frequently attributed to their racial background. ${ }^{17}$

\footnotetext{
${ }^{16}$ For more on the history of anti-Chinese discrimination in the United States see, Stuart Creighton Miller, The Unwelcome Immigrant: The American Image of the Chinese, 1785-1882 (University of California Press: Berkeley, 1969); Daniel T. Rodgers, The Work Ethic in Industrial America, 1850-1920 (Chicago: University of Chicago Press,1974), pp. 69, 221, 162-173, esp. 171-172; Alexander Saxton, The Indispensable Enemy: Labor and the Anti-Chinese Movement in California (Berkeley: University of California Press, 1971), pp. 179-259, esp. 220-228.

${ }^{17}$ English-language newspapers are particularly rich sources for understanding the anti-Chinese sentiment that spread across the western United States from the $1860 \mathrm{~s}$ through the 1920s. In these papers, it is clear that the debate over Chinese immigration was complex to the point of being ironic. For instance, while some whites chastised Chinese for their unwillingness to assimilate, others cared little about the issue, and, instead, complained about Chinese laborers willingness to work long hours at low wages. A third group cared little about the work ethic of Chinese or their unwillingness to assimilate to the American mainstream and went so far as to praise
} 
At the same time, whites viewed Chinese merchants and labor contractors more favorably, believing these groups had more fully conformed to conventional market behavior. Unlike laborers, merchants did not pose a competitive threat to whites. They operated businesses that catered to Chinese or operated labor contracting services that whites relied on to fill jobs which white laborers were less willing to take. As illegal immigration networks started to develop, then, Chinese merchants were in a good position to collaborate with whites who owned and operated steamships. Not only were Chinese merchants well regarded by their white counterparts, they were also well connected to the majority Chinese population. For decades, Chinese merchants had provided financial and social aid to immigrants, particularly laborers, who relied on their services for their livelihoods in the United States. As the Blum-Wilson smuggling network grew, the position of Chinese merchants in the immigrant community and the relationship already established between whites and Chinese merchants came to fruition.

To succeed in the smuggling of immigrants and goods, Blum and Wilson first had to recruit federal, state, and provincial officials from Oregon and British Columbia. The first two collaborators were signed on in the spring of 1892 when Glen O. Holman, notary public for the State of Oregon, and P.J. Bannon, a Portland attorney, joined the MSC owners. Holman agreed to make 500 fraudulent Chinese certificates, with his notary seal attached, which assured merchants their return status

Chinese for their work in developing the U.S. West through their work on railroads and in clearing land for agricultural development. This last group did, however, complain that Chinese had an inherent propensity for poor morals. They perceived immigrants as a threat to the moral code of the majority white population. 
to the United States. ${ }^{18}$ P.J. Bannon agreed to furnish the steamship owners with, as a first installment, twenty blank immigration certificates with his name attached, purporting to have witnessed whites testify that an incoming immigrant was a merchant and not a laborer. ${ }^{19}$ After obtaining these documents from Holman and Bannon, the steamship operators approached two additional government officials, the newly appointed Collector of Customs in Portland, James Lotan, and U.S. customs official C.J. Mulkey, who was recruited to the Blum-Wilson network with a monthly pay-off of approximately $\$ 1,200 .^{20}$ As head of the Portland customs house, Lotan served as the inspector of all incoming ships and regulated all other inspectors at the port. With Lotan and Mulkey involved, Blum and company controlled the Port of Portland. They then turned to the task of finding and recruiting Canadian counterparts, drawing upon relationships already established through their legal business ventures.

As customs agent in Victoria, British Columbia, Major John Wilson performed the same duties as James Lotan and his staff of inspectors in Portland. Before the smuggling operation began, Wilson had served as agent for the three legal businesses operated by Blum and Dunbar: the Oregon Flouring Mill, Dunbar Produce and

${ }^{18}$ See, Shawn Aubitz, "Tracing Chinese Immigration into the United States: The Use of Federal Documents-The Case of Moy Ni Kee," Ethnic Forum: Bulletin of Ethnic Studies and Ethnic Bibliography, 2 (1987), pp. 64-75.

${ }^{19}$ U.S. v. Wilson, File 3875, RG 21, NARA.

${ }^{20}$ In December 1893, C.J. Mulkey admitted that he was bribed to take part in the smuggling of opium and immigrants into the United States. Apparently, members of the Wilson-Blum network frequently complained that Mulkey and chief customs inspector, James Lotan, were making too much money for their role in the smuggling operation. Daily Oregonian, Dec. 10, 1893. 
Grocery Company, and the Merchant's Steamship Company. In this role, Wilson led the inspections of all incoming shipments arriving aboard MSC vessels. Equally important, Wilson had extensive connections with the Chinese merchant community throughout the Puget Sound-British Columbia region. His job inside the smuggling ring was to recruit Chinese opium manufacturers by offering them two services: ships large enough to smuggle hundreds of pounds of opium through customs and a system for smuggling immigrants from Canada into Portland, both highly lucrative business ventures. Like Chinese merchants in Portland, merchants in British Columbia held high status among the immigrant population. They provided financial and labor services to Chinese immigrants and connected them with white business owners. Given these Canadian Chinese merchants' connections, they had little difficulty finding immigrants who wanted to enter the United States illegally. For the white organizers, Chinese merchants in Canada provided important services. They found immigrants who needed the services of the MSC, located portraits of Chinese immigrants to attach to fraudulent certificates, and signed documents necessary for the transport of immigrants from Canada to Portland. In court testimony, Nathan Blum described the system:

I explained to him [Wilson] that we had made a deal on this side, whereby we could land Chinese laborers, and that the three large opium firms over there, Qoung Young [sic], Quong On Lung and Tai Yuen, were ready to furnish him with pictures. That he should take those pictures and send them over here to Dunbar and myself, giving the names of the Chinamen, their age and description as near as he could, that we would have certificates made out, to 
turn to them and that the price for bringing them over and landing them was $\$ 120 . .^{21}$

Of this $\$ 120, \$ 50$ was paid upfront by Chinese immigrants, usually through their Chinese merchant sponsors. Upon safe landing in the United States, another $\$ 70$ was paid. In letters submitted as evidence in U.S v. Wilson, passage to the United States was set at $\$ 100$ between the Chinese and white organizers. Of this, fifty dollars was distributed for getting each Chinese passenger through customs, ten dollars as fare to the ship owner, and the remaining forty dollars went "to the bank,"--that is, into the pockets of the white and Chinese smugglers. After Wilson stated that he could not "work here on less than $\$ 60$ " and Chinese demanded that they make an additional ten dollars on each passenger, the fee for passage was raised to $\$ 120$.

Wilson's role in the operation was crucial, as he served as the head customs inspector on the Canadian side of the border. Shortly after the agreement was set, Blum traveled to Victoria to demonstrate how the certificates for Chinese immigrants needed to be completed in order to pass immigrants through customs inspections in Portland. As an agent for the steamships Haytian Republic and Wilmington, Wilson signed, at the close of this first meeting, 100 fraudulent certificates, thereby guaranteeing the right for Chinese to travel from Canada to the United States. Over the period of two years, Wilson would sing his name many more times, providing a necessary connection to Canada for the Blum syndicate. When this meeting ended, the

${ }^{21}$ U.S. v. Wilson, File 3875, RG 21, NARA. Wilson's role was to go among the merchants of Chinatown, then locate immigrants who desired to enter the U.S. illegally and who were willing to pay $\$ 120$ to do so. 
cross-border network was put into operation. Now the men involved on both sides of the border needed only to locate Chinese immigrants who, in Canada, wished to enter the United States, outside Chinese merchants who wanted in on the opium trade, and Chinese merchants in Portland who wished to purchase smuggled opium.

\section{Racial Crossing and Collaboration}

As Erika Lee has observed, illegal Chinese immigration was a business defined by multiracial connections and relationships. ${ }^{22}$ Between 1882 and the turn of the twentieth century, judges and officials on the both sides of the United States-Canada border aligned themselves with illegal smuggling networks specializing in opium and immigrant trafficking. For Chinese, the business of smuggling was especially profitable. Merchants created a system in which immigrants borrowed money from merchants to pay their passage, agreeing contractually to repay it later, with interest, on a rotating credit system. ${ }^{23}$ Relationships between whites and Chinese also proved profitable for Chinese merchants who provided whites with a steady flow of illegal

${ }^{22}$ Lee, "Chinese Exclusion at the Borders with Canada and Mexico," p. 62.

${ }^{23}$ The credit-ticket system, which apparently was be used by merchants and immigrants in Canada and the United States between 1850 and the turn of the century, began in the southern delta regions of China. Here, emigrants traveling abroad were divided into two groups; those who were taken overseas in the coolie trade (especially to Latin America and Southeast Asia) and those who left voluntarily. Individuals who paid for their own fares were free, whereas those whose passage was financed by the so-called credit-ticket system were classified as semi-free. Through critics at the time generally classified Chinese as "coolie laborers," in reality, most emigrants to California, and later those who came from Canada to the United States in the BlumWilson network, either paid their own way or, and especially in the Blum-Wilson smuggling operations, secured passage under the credit-ticket system. See Sucheng Chan, This Bittersweet Soil: The Chinese in California Agriculture, 1860-1910 (Berkeley: University of California Press, 1985), pp. 21-26. 
immigrants as well as a list of Chinese merchants who wished to purchase unchecked opium. $^{24}$

Three main opium manufacturers formed the basis of the Blum-Wilson network. The Tai Yuen and Company, Quong Yuen Tai Company, and Kwong On Lung served as go-betweens for potential Chinese immigrants and also served as the primary distributors of opium going from British Columbia to Portland and even San Francisco. Chinese opium manufacturers' influence throughout British Columbia and the United States was noteworthy, and they likely shipped opium to urban and rural Chinese communities alike.

Generally, the smuggling conspiracy between whites and Chinese operated smoothly. Documents were forged in Portland and then transferred to British Columbia by captains who controlled their ships' pursers. The three primary Chinese merchant coordinators kept up a steady supply of illegal immigrants for the steamship company, and both sides profited. However, in the day-to-day business of the ring, white and Chinese relations were not always placid. Chinese merchant organizers frequently failed to sign the forged certificates properly and occasionally they also failed to provide the required photos for attachment to the fraudulent certificates. ${ }^{25}$

${ }^{24}$ Shipments of opium were, like all imported items at the time, required to go through customs checks where inspectors would list all items being brought into port and add the various taxes and tariffs to the costs of importation. Although it is unclear what the taxes and tariffs on opium were in the 1890s, it can be assumed, due to the quantity of opium being smuggled by the Blum-Wilson network, that profit margins increased significantly by not claiming shipments at customs.

${ }^{25}$ The three Chinese firms, the Tai Yuen Company, the Quong Tai Yuen Company, and the Quong On Lung Company were asked to locate other immigrants already in the British Columbia region who wanted to bring Chinese illegally to the U.S. and 
Technical problems such as these were often the subject of correspondence between Blum, Dunbar, and Wilson, but they did not trouble the smuggling operations as did the Chinese merchants' unwillingness to operate their end of the business according to standard procedures - as the whites understood such. The illegal nature of smuggling only increased the opportunity for Chinese to bend white standards of business.

The multiracial nature of the Blum-Wilson smuggling network both encouraged collaboration between Chinese and whites and highlighted the inherent differences between the two groups. White operators were used to operating business on formal contractual agreements that outlined procedures in detail and required payment for services ahead of time. Chinese merchants, on the other hand, conventionally arranged business ventures on the basis of verbal agreements and paid for services at a later date-an example being the rotating credit system between Chinese workers and labor contractors. In the minds of their white partners such a system was foreign and unreliable. For Chinese merchants, retention of their system of business served as a means of control over smuggling operations. A September 1892 letter between William Dunbar and Major John Wilson illustrates the issue:

I again take up the matter of final payments[.] The firms are not treating us right[.] We take their words for $\$ 70.00$ and surely when we wire the money... men are landed they should take our word[.] You had better threaten them a little and tell them that you will personally guarantee my statements and if not correct will refund[.] They know now since each boat has made a trip that I

Canada. Once found, these merchants were to gather photos of Chinese men that resembled the illegal immigrant closely enough to pass him through customs and for proof of identity if the immigrant ended up detained and in court. 
carry out all I agreed to do. I think with a stiff talk from you they will come to time[.] You know by experience they bluff to the last moment but when we commence bluffing back they come to time[.] The fact of the matter is they are making $\$ 50$ per head clear and they do not want to lose their business and your guarantee I think will satisfy. ${ }^{26}$

In another exchange, the unwillingness of the Chinese merchants to compromise their business models was noted when Dunbar again wrote to Wilson:

I have read over your letter this morning to Mr. Blum regarding the payment of the Chinese passage money. I cannot understand why the firm should take any exceptions to paying on arrival of the passengers here. The firm which you mention appears to be very independent. When we buy any goods from them, they make us pay cash in Victoria. And yet when we do any business for them, they want to take their own time in paying for it. We have always carried out our part of the agreement promptly, and we certainly think they ought to do theirs. There is no reason why we should wait their pleasure after the men arrive here for them to pay their passages. We have to put it up here before they get ashore and certainly after telegraphing their delivery the matter ought to be promptly settled. We cannot handle it otherwise so if they do not want to conform to this, we will have to find other places to deal. We have faithfully carried out our arrangement as made and shall expect all of those doing the business with us to do the same. ${ }^{27}$

Considering the type and amount of business that the white and Chinese conspirators conducted, and the large investments that Chinese merchants made in the venture, it is not surprising that the Chinese would seek to maintain economic autonomy according to their own notion of business. The Chinese merchants had too

${ }^{26}$ U.S. v. Wilson, File 3875, RG 21, NARA.

${ }^{27}$ Ibid. 
great a financial investment in the venture to let whites bully them on matters of payment - the extent of which is apparent in the cipher code used by the Blum-Wilson organization. Three sets of cipher codes were developed by the white organizers to hide illegal smuggling of opium and, to a lesser degree, Chinese immigrants. Blum, Wilson, and Dunbar each received one set of cipher. They used the cipher code in letters and telegrams sent between Portland and British Columbia.

Three cipher codes were distributed among the white organizers and carried titles that signified to whom each code belonged. Submitted as evidence in the U.S. v. Wilson, the cipher code titled marked "Morgan" is included below (Figure 1) and was used by Major John Wilson to coordinate opium shipments purchased in British Columbia and shipped to coordinators in Portland. Following these codes, three primary Chinese opium manufacturers conspired with Wilson in Vancouver and Victoria. Kwong On Lung, Tai Yuen, and the Qwong Yuen Tai Company organized both the transfer of immigrants and large shipments of opium from British Columbia to Portland. Opium was eventually sold to Chinese merchants in Portland and as far south as San Francisco. ${ }^{28}$

${ }^{28}$ Shipments of opium were generally loaded in British Columbia, broken into smaller cargos in Portland, and eventually distributed in Portland and San Francisco. In October 1892, William Dunbar and Nathan Blum traveled to San Francisco with 2,100 pounds of opium in two or three large trunks. Two of the trunks were seized at the transfer office and the rest were sold to Chinese merchants in San Francisco. In September $1892,1,400$ pounds of opium landed in Portland. Approximately 700 pounds were delivered to Chinese merchants in downtown Portland and the rest was loaded aboard another steamer to be sold in San Francisco. These were the general procedures for all opium shipments in the Blum-Wilson syndicate. See the Daily Oregonian, Nov. 19, 1893. 
On a first look, we can gain some understanding of the intricate system that whites and Chinese devised to conceal the shipping of contraband goods and immigrants. For instance, "cheese," "cement," and "coal" all denote trouble with the shipment of goods. Sometimes Wilson was unable to meet ships in British Columbia, especially if they were delayed because of poor weather or if customs agents not associated with the network were present at the ports. The term "Dunsmuir" indicates that prices for shipping opium and immigrants were fluid, affecting the timing of shipments. Finally, agricultural references like "wheat," “oats," and "flour," hidden behind tonnage measurement, illustrate the size of the opium shipments transported between Oregon and British Columbia—amounting from 100 to 500 pounds.

While opium was frequently confiscated at customs after captains failed to specify the actual amount shipped, it was not illegal to bring opium into the United States until $1906{ }^{29}$ However, the members of the Blum-Wilson network always concealed their shipments of the drug because of the massive amounts of opium they were transporting. On the other hand, illegal immigration was not concealed in the cipher code. Rather, the white organizers communicated by telegraph, frequently

${ }^{29}$ Thomas Gearin, prosecuting attorney in U.S. v. Wilson, specified "that the government had to show that the opium was imported, because it would not be 'smuggled' unless it were clandestinely imported, and it had to be so imported before it could be unlawfully concealed or transported within the jurisdiction of the court." Daily Oregonian, Dec. 2, 1893. 


\begin{tabular}{|l|l|}
\hline \multicolumn{2}{|c|}{ "Morgan"30 } \\
\hline Eggs, I will go to Vancouver to meet Wilmington & Cowan, K[Q]wong On Lung \\
\hline $\begin{array}{l}\text { Apples, I delivered it safely on board the } \\
\text { Wilmington }\end{array}$ & Johnson, Tai Yuen \\
\hline $\begin{array}{l}\text { Cheese, I could not deliver it at all as things did } \\
\text { not look right }\end{array}$ & Leiser, Qwong Yuen Tai Co. \\
\hline Plums, I will go to Vancouver to meet Haytian & Rates, Wilmington \\
\hline Pears, I delivered it safely on board Haytian & Insurance, Haytian \\
\hline Barley, I delivered 100\# & Chop, Vancouver \\
\hline Wheat, I delivered 150\# & Soda Crackers, buy 100\# \\
\hline Oats, I delivered 200\# & Extras Crackers, buy 150\# \\
\hline Flour, I delivered 250\# & Oyster Crackers, buy 200\# \\
\hline Corvallis, I delivered 300\# & Picnic Crackers, buy 250\# \\
\hline Salem, I delivered 350\# & Sweet Crackers, buy 300\# \\
\hline Dayton, I delivered 400\# & Ginger Snaps, buy 350\# \\
\hline Walla Walla, I delivered 450\# & Mixed Crackers, buy 400\# \\
\hline Albany, I delivered 500\# & Cookies, buy 450\# \\
\hline Rice, I have drawn 5 days st & Jelly, buy 500\# \\
\hline Sugar, I have drawn 7 days st & Cement, there are too many officers around now \\
\hline Hops, I have drawn 8 days st & Tons, I will try to put it aboard here \\
\hline Peas, I have drawn 9 days st & $\begin{array}{l}\text { Coal, I could not deliver here will go with it to } \\
\text { Vancouver }\end{array}$ \\
\hline Beans, I have drawn 10 days st \\
\hline from British Columbia to Portland aboard the Haytian Republic and Wilmington. \\
\hline & Dunsmuir, Prices have advanced considerably \\
\hline
\end{tabular}

30 "Morgan" referred to John Wilson in the sense that he was the person who delivered the opium to merchants and coordinated the buying of opium for these same merchants. The information collected here was originally submitted as a list to the court in U.S. v. Wilson, File 3875, RG 21, NARA. The cipher code was used loosely in telegrams sent between Nathan Blum, William Dunbar, and John Wilson. Sometimes, names and shipments were concealed by cipher codes; in other cases, the communications were surprisingly open about who was receiving shipments of cargo. The variation in the code 
listing the names and numbers of immigrants they were transporting illegally to the United States. $^{32}$

Specific telegrams between various members of the Blum-Wilson network explain the cipher code further. For instance, in October 1892 William Dunbar wrote,

seems to have been based on the subject being discussed. When discussing shipments of opium, the code words, "flour," "wheat," and "chop," were used frequently and testify to the large shipments of opium that were being transported between British Columbia and Portland. On the other hand, when passengers arrived at ports of entry or when fraudulent certificates were sent to British Columbia for signatures and approval, no code was used. Instead, the telegrams stated openly what and who was making the fraudulent documents and to whom they were being sent. This variation is particularly notable since at the time, immigration was prohibited but was not hidden while opium was not prohibited but was hidden behind the cipher code

${ }^{31}$ Ibid.. In court testimony, Charles Murphy, district attorney for the State of Oregon, produced a series of letters written between the men of the Blum-Wilson syndicate. One letter, signed by Major John Wilson, alluded to the "Morgan" cipher. Addressed too William Dunbar at Portland, the letter stated that 425 tons of coal had been sent from Victoria to Portland but had not been packed suitably in egg boxes as they were to frail. Attorney Murphy stated that "the coal alluded to must have been opium" because coal would not have been shipped in egg boxes. In a more explicit statement, Nat Blum testified that the ring brought in approximately $\$ 200,000$ worth of opium in one year. They received statements nearly every trip from Major Wilson of the quantity of opium shipped, money paid, and when shipment would arrive in Portland, all under the cover of the cipher. One statement was offered in evidence and gave notice of the shipment of 425 tons of coal, which Blum testified meant 425 pounds of opium. William Dunbar would go on to deny any knowledge of the cipher codes, the transport of opium aboard his ships, and any association with Nat Blum. See the Daily Oregonian, Nov, 30, 1893; Dec. 2, 3, 1893.

${ }^{32}$ Arranging the retrieval of opium and immigrants was no small task. Oftentimes, shipments of both were picked up, not directly from urban ports, but instead from stashes on small island outcroppings between ports like Portland and Vancouver. Again, The West Shore reported, "At the entrance to Victoria harbor there is a buoy off the Indian reserve, and this is where the smuggling vessels lie at anchor, presenting the most innocent aspect imaginable. When the financial arrangements for a cargo of opium and Chinese have been completed, small lots of the former are secretly taken on board, and enough Chinamen to make a load are told to get ready. Toward the close of evening two or three will stroll over to the reserve disguised as dishwashers. They are taken aboard one of the boats, and in the morning she goes out to fish." The West Shore, March 14, 1891. 
“There are several of your largest flour accounts who are considerable overdue. Can you push up the amount due and remit, we are very short and require all the funds we can see." 33 If it is assumed that Wilson and Dunbar used the word "flour" as a code word for opium, it can be assumed from this message that "largest flour accounts" refers to the Chinese opium accounts that Wilson coordinated in British Columbia. ${ }^{34}$ The frustration conveyed in the telegram demonstrates how the payment system between Chinese and white conspirators often produced delays in the shipments and other difficulties in dealing with customs officials.

In addition to coordinating specific orders of opium shipments, Blum and Wilson used the cipher code to coordinate the receipt of opium shipments in British Columbia and Portland. Chinese and white middlemen in Portland often retrieved shipments and distributed them to opium merchants in Portland. During one shipment, Nathan Blum instructed Wilson, "Rates is due Van[couver] about Wednesday morning and you must get Leiser to let 2 or 3 of his countrymen take it up as baggage and deliver to Pat [Patterson] or you can ship it to DeWolf as liquor and go up and unpack into a $2^{\text {nd }}$ hand trunk and let the trunk go as baggage." As the cipher code denotes, "Leiser" refers to the Qwong Yuen Tai Company and "Rates" the steamship Wilmington. They also used the cipher code to organize Chinese middleman who picked up shipments at port. In court testimony, Nathan Blum

${ }^{33}$ U.S. v. Wilson, File 3875 , RG 21 , NARA.

${ }^{34}$ Letters submitted as evidence in court were from a cache held by Wilson. While Wilson and Blum and Dunbar did in fact do business in agricultural products, the letters from this collection clearly pertained to the smuggling operations specifically. Considering this fact, it is not a stretch to assume the men were discussing opium and Chinese accounts in this collection of letters. 
elaborated on this, describing an exchange with a contact by the name of Jackling.

The letter stated, "Moy Heim [sic] from Portland came over to-night and will take a haul away with him[.] He takes for 100.00 and beats up Chinatown for them. ${ }^{\text {"35 }}$ In Portland, shipments of opium packed in trunks or as various legal products, were regularly thrown overboard and picked up by one of many white middlemen who lived downriver from the main ports along the Portland waterfront. These men also provided storage facilities for opium until it could be sold to Chinese merchants in Portland.

It was more difficult to land opium in many cases than it was to land Chinese immigrants. One account on the matter noted,

The landing of the opium is the most difficult part of the work. A Chinaman can be landed near some town and find his own way to a place of security, but the opium has to be carried, and it is not always easy to get in into Chinatown undetected. At points on the American shore repositories are maintained by some smugglers, whose opium is stored until opportunity offers to carry it away. $^{36}$

Beyond the cipher code and its relationship to the opium trade between Portland and Canada, letters in evidence in U.S. v. Wilson establish the role Chinese

${ }^{35} \mathrm{Ibid}$.

${ }^{36}$ The West Shore, March 14, 1891. In the Blum-Wilson syndicate, three white men served as primary repositories for opium shipments in Portland. Sig Baer, Robert Garthorne, and H.T. Berg retrieved shipments of opium thrown overboard by steamer engineers for pick-up in the Willamette and Columbia Rivers. The three men also offered their homes to the Blum-Wilson syndicate for storage of large shipments of opium between the time they were landed and when they were broken down for distribution in Portland, San Francisco, and other destinations along the coast and throughout eastern Oregon. 
merchants played in the recruitment and transport of illegal immigrants. As

smugglers, Chinese merchants played a central role, organizing potential immigrants and providing financial loans to the poor among them. Numerous letters display the system that tied together Chinese merchants, immigrants, and the Vancouver-toPortland Blum-Wilson network. For instance, in a letter to Wilson, Blum noted that a check for $\$ 548.85$, sent by a Chinese firm in British Columbia, had arrived safely in Portland. It covered the cost of eleven fraudulent tickets aboard one of the Merchant's Steamship Company's steamers. And in another letter Blum verified the receipt of $\$ 1,249.40$, paid in one lump sum, for the passage of thirty-four immigrants brought to Portland per the request of a key figure in the smuggling operation. Because each passenger paid about one hundred dollars for passage, these numbers indicate the number of illegal immigrants (nine to twelve) traveling between Canada and Portland. Illegal immigrants coming to British Columbia and the United States direct from China also paid a one hundred dollar fee for their fraudulent entry certificates. ${ }^{37}$

${ }^{37}$ In some cases, the Blum-Wilson network brought Chinese laborers and family members directly from China to the United States and British Columbia, especially when high-ranking Chinese merchants requested such. William Dunbar testified that over an eighteen-month period, approximately 1,200-1,400 Chinese were brought from China directly. He did not, however, admit that all of the immigrants were brought to the United States and British Columbia illegally, or through the fraudulent certification produced by P.J. Bannon. Yet, in June 1893, P.J. Bannon admitted to delivering about 100 fraudulent certificates to William Dunbar. Dunbar then turned these over to John Ross and E.P. Thompson. The two men took these blank documents, with a list of names, to China, where they located the Chinese requested and completed the documents. The men made frequent trips to China, and it can, on this evidence, be assumed that many of the Chinese immigrants who came directly from China did so under the auspices of forged return certificates. See the Daily Oregonian, Dec. 21, 1893. 
The participation of Chinese merchants increased the efficiency, success, and amount of shipments in the Blum-Wilson operation. However, with the success of the enterprise came increased public and official scrutiny. Anti-Chinese immigration proponents frequently published pamphlets detailing the increase in illegal smuggling operations and the failure of customs agents to stop the trend. Nathan Blum wrote to John Wilson,

Under a lately published pamphlet on the alighting of Jaybirds [Chinese immigrants] if they are not laborers or working birds and have been here before they may alight. Have Jim [James Lotan] quietly work along and land those that he can safely and let balance go to court. ${ }^{38}$

Increased complaints over illegal immigrants complicated the operations of the BlumWilson network throughout the fall and winter of 1892. As William Dunbar wrote to John Wilson,

I cannot understand who has any right to make a fuss over this. Whether they are selling certificates or not, it is no ones business...the treasury department is able to look after that without the newspaper reports. The Oregonian has given them a pretty stiff rebuke when it said some imaginary brain was telegraphing to that effect. ${ }^{39}$

Increased public and official scrutiny of custom houses and efforts to identify and catch fraudulent documents and illegal immigrants led the Blum-Wilson organizers to reassess their operations in the spring of 1892 .

${ }^{38}$ U.S. v. Wilson, File 3875 , RG 21, NARA.

${ }^{39}$ Ibid. 
A major problem that underscored this reassessment was customs agents who refused to participate in illegal smuggling operations. In his court testimony, Nathan Blum described the challenges to these hurdles and his syndicates' response. Blum testified that one inspector in particular, George W. Dillon, was constantly "telegraphing over here or giving information to Mulkey" about the illegal immigrants coming ashore aboard the two steamships. ${ }^{, 40}$ Blum also testified that chief customs inspector for the United States, James Lotan, suggested overcoming the challenges Dillon posed by bribing him with money made from the smuggling operation or pulling him off his post as customs agent at Vancouver. Shortly thereafter, Dillon was moved to a new post at Tacoma, through which immigrants and opium were not being smuggled. ${ }^{41}$

However, even with the help of Mulkey, Lotan, and other customs agents on the Blum-Wilson payroll, by the winter of $1892-93$ it became clear that, no matter how

${ }^{40}$ C.J. Mulkey was an inspector for the United States Treasury Department. His duties as agent were to examine the books of customs houses and enforce navigation and Chinese exclusion laws, especially concerning the smuggling of Chinese. His district included Oregon, Washington, and Alaska. He first met Nat Blum on the wharf near the Haytian Republic in Portland. Blum took him to a local hotel, where he served the inspector a bottle of fine wine before confronting Mulkey on his reporting the shipments of opium shipped aboard the two Blum-Wilson steamers. Although Mulkey would later deny being bribed at this time by Blum, other testimony shows that Blum and Mulkey established their working conditions at the hotel over a two-day period. The final agreement was to pay Mulkey approximately $\$ 1,200$ a month to lie about shipments coming into Portland aboard the steamers and those being shipped out to British Columbia, San Francisco, and as far away as Honolulu, Hawaii. Daily Oregonian, Dec. 20, 1893.

${ }^{41}$ Ibid. George W. Dillon would later testify that, while acting as a special treasury agent, he had never received instructions from C.J. Mulkey to relax his vigilance in looking after the business of the Merchant's Steamship Company. Yet, Dillon did support the smuggling operations during his inspections of ships and frequently wrote letters to C.J. Mulkey under the name Oliver Budd at Tacoma. 
large the bribes or how intense the threats, the Blum-Wilson ring faced increased difficulties in getting its human cargos past customs officials. Fraudulent certificates were frequently questioned as border controls tightened. Chinese were pulled off ships and detained at customs stations or in county jail. Under the Chinese Exclusion Act of 1882, however, these detained Chinese were afforded the right to file writs of habeas corpus in district court. ${ }^{42}$ Through this procedure, Chinese had the right to contest their detention and establish their right to land in the United States. To do so, they had to locate at least one white citizen who would testify to their legal status as well as well as one or more legal Chinese resident who would do the same. In the winter of 1892-93, the increase in these detention cases was more and more the subject of letters from Dunbar to Wilson. In one, Dunbar wrote, "Regarding the passenger business. I think you understand the situation. Today most of our time has been taken up in the US court with the Habeas Corpus cases. There is [sic] 28 of them, which will take us all day [and] tomorrow to get through. I think most of them will land, still there may be a few who will have to return."43 For detained immigrants, detention always threatened deportation, but the Wilson ring, to maintain their business, did all they could to ensure favorable outcomes by arranging court cases ahead of time.

${ }^{42}$ Lucy Salyer has studied the history of habeas corpus cases among Chinese in Laws Harsh as Tigers: Chinese Immigrants and the Shaping of Modern Immigration Law (Chapel Hill, N.C.: University of North Carolina Press, 1995). See, also, Charles McClain, In Search of Equality: The Chinese Struggle Against Discrimination in Nineteenth-Century America (Berkeley: University of California Press, 1994).

${ }^{43}$ U.S. v. Wilson, File 3875, RG 21, NARA. 


\section{Habeas Corpus and the Portland Chinese connection}

While Chinese merchants on the Canadian side of the Blum-Wilson network found and organized Chinese immigrants seeking entry into the United States, Chinese merchants in Portland served a different but equally important role in the illegal immigration operations. Seid Back, Lee Wing, Charley Young, Ju Hauk, and Chee How each served as interpreters during court cases in which Chinese detainees sought writs of habeas corpus to allow them to remain in the United States. As interpreters in the hearings, these prominent Chinese merchants were granted preference over their low-ranking illegal immigrant counterparts. ${ }^{44}$ For instance, the Blum-Wilson network depended on middle-level Chinese merchants to recruit common immigrants who wished to enter the United States. Each immigrant was charged a passage fee that was seldom less than the substantial charge of $\$ 120$ dollars. Without an alternative these Chinese paid heavily and traveled in poor conditions aboard steamships. Little more than commodities, common immigrants were referred to as "Chinamen" or "heathens."

On the other hand, middle-level Chinese such as the opium merchants in British Columbia were treated with a substantial measure of trust and respect. They were indispensable to the smuggling business, recruiting illegal immigrants and

${ }^{44}$ In the following passages I will use "common immigrants" to describe illegal immigrants traveling from British Columbia to Portland, "middle-level Chinese," to describe merchants and opium manufacturers who facilitated the recruitment of Chinese and the ordering and distribution of opium, and "high-level Chinese" to denote the wealthy merchants and court interpreters who worked alongside the BlumWilson network in Portland. From these categories we can see the status hierarchy that Chinese in America inhabited and how it played out among Chinese and between Chinese and whites involved in the Blum-Wilson smuggling enterprise. 
simultaneously purchasing large shipments of opium. Furthermore, middle-level

Chinese merchants in Canada, well connected to the large Chinese communities in Vancouver and Victoria, collected the photos that Blum and Wilson attached to fraudulent entry papers. To whites, middle-level Chinese merchants were considered "friends" who might deserve preferential treatment depending on the nature of their orders and the help they provided in smuggling goods and immigrants. ${ }^{45}$

Even more than the middle-level Chinese merchants, whites treated the highest-level Chinese merchants, including customs and court interpreters, with even greater trust and respect. During court testimony in U.S. v. Wilson, this preferential treatment was apparent. Interpreters such as Seid Back frequently enjoyed discounted rates aboard the steamships owned by Blum and Dunbar and accommodations equal to those given to preferred white partners. Friends of Seid Back enjoyed similar treatment on the strength of Seid Back's name. As Nathan Blum testified, "Seid Back,

${ }^{45}$ Middle-level merchants often made special requests for immigrants to be brought to the United States and British Columbia. During the fall of 1892, for instance, a member of the Tai Yuan Company requested a young male friend or relative be brought to the United States directly from China. Young Chinese men were often turned away at ports because they did not qualify for the categories of merchant, diplomat, or student that would otherwise allow them entry. In this case, special arrangements were made by the Blum-Wilson coordinators to create a special document, at a hefty price, that would allow the youngster to enter the United States for eventual transfer to the Tai Yuen Company member. See, Ibid. In another case, William Dunbar made special arrangements to bring Chinese prostitutes, at $\$ 450$ a piece, to Chinese merchants in British Columbia. He stated, "there was a great deal of trouble landing women and it was worth more than men," Daily Oregonian. Dec., 21, 1893. 
in addition to getting Chinamen landed here at a reduced rate also paid a reduced rate of $\$ 20$ for passage instead of $\$ 50$ like the rest of the Chinamen., 46

Seid Back and his associates played a crucial role in the illegal ventures of Blum and Wilson. Not only did Seid Back serve as a primary interpreter aboard ships and in habeas corpus proceedings, he also recruited Chinese interpreters and oversaw their work in the courtrooms for the Blum-Wilson syndicate. This was particularly important for Chinese immigrants because in many cases the habeas corpus hearing was their last chance to stave off deportation. For white smugglers like Blum and his associates, Chinese interpreters ensured that their operations would remain concealed-and successful. Because Seid Back had an intimate understanding of the courts and was well regarded in both the Chinese and white communities in Portland, he was a crucial link in the success of both immigrants and those who conducted the smuggling operation. ${ }^{47}$

Not only did high-level Chinese merchants like Seid Back serve as interpreters in habeas corpus cases, they also worked alongside criminal and non-criminal customs agents aboard the steamships owned by the Merchants Steamship Company. During Wilson's trial, Nathan Blum elaborated on this point. When the court asked whom the

${ }^{46}$ U.S. v. Wilson, File 3875 , RG 21 , NARA. When Blum referred to a $\$ 50$ charge for passage aboard MSC steamships he probably referred to the reduced rates charged to middle-level Chinese merchants. Most middle and high-level Chinese received reduced rates while common immigrants paid full fare.

${ }^{47}$ Seid Back was a wealthy merchant in Chinatown and unofficial leader of Portland's Chinese community. He frequently entered court pleas on his own behalf, served as a surety for Chinese indicted in civil and criminal cases, and associated with prominent white Portlanders, with some of whom he had extensive business dealings. In fact, during the trial of U.S. v. Wilson, Seid Back was supported by some of Portland's best-known white merchants, including Henry Failing and H.L. Hawkins. 
white conspirators had on board the ships interpreting for the Chinese immigrants, Blum stated, "Why Seid Back he was there—well, I should say in about 90 percent of the cases. ${ }^{.48}$ And when the prosecution presented evidence about the role interpreters played in the habeas corpus hearings, Nathan Blum again elaborated on the role that Chinese interpreters played in the scheme;

These Chinamen were brought in this court to be landed on a writ of Habeas Corpus, and Seid Back got this English speaking Chinaman here by the name of Lee Wing who acted as interpreter, and it was quite an advantage to these chinamen, and he fixed the thing all up with Lee Wing in my presence. I heard Seid Back fix this thing up in my presence. He told Lee Wing what questions to ask and what answers to make, and it made no difference what these chinamen on this stand said, whether they swore to anything relating to the case or not, this chinaman interpreted it so, and he stood right here. ${ }^{49}$

Blum testified later that Seid Back and his associates also recruited Chinese who coached detained immigrants on their court testimony. Seid Back's Chinese associates had free reign in the county jails where detained immigrants were held. They appeared constantly-and successfully_-in court, aiding detainees in establishing that their entry was legal. In one particular case, the judge, apparently suspicious of the Chinese interpreter, requested the court rotate in a new interpreter for habeas corpus cases. As Nathan Blum later testified, Seid Back arranged the switch;

${ }^{48}$ Ibid..

${ }^{49}$ Ibid. 
Seid Back took me [Blum] down to his confidential chinaman...Charley Young, and Charley was as good as the other fellow only he had a better memory; he did not have to write it [the defense statement of Chinese detainees] down on the book. Charley and I came up to the county jail where these chinamen were incarcerated and the jailer admitted Charley and I in there and I told Charley what to tell the Chinamen and he told it to them, and when he got on the stand the next day, and before going in the Court, I introduced Charlye [sic] Young to Judge Gilbert as a reliable interpreter and he acted as interpreter and we landed these chinamen. ${ }^{50}$

\section{Conclusion}

The close collaboration between Chinese interpreters and whites in both smuggling and, in turn, manipulating of the courts, encouraged the crossing of racial barriers that otherwise divided the white and Chinese populations. While common immigrants suffered constant discrimination on the part of whites, middle and highlevel Chinese traveled in elite circles despite the racial tensions that marked whiteChinese relations. The relationships that developed out of collaboration between whites and middle and high-level Chinese merchants afforded these Chinese no small measure of power among both their countrymen and whites. Chinese merchants like Seid Back enjoyed high status among the Chinese community for facilitating immigration during the exclusion era, as well as for the financial assistance they provided immigrants who otherwise could never have afforded to immigrate to the

\section{Unites States.}


Well known Chinese merchants in Portland used their status in both the

Chinese and white communities to alter the outcomes of habeas corpus cases. They were allowed to board ships and coach Chinese on their court testimony because they were respected as English-speakers among a white community that privileged those immigrants who had adapted to the English language and U.S. market economy. They entered courts on the recommendation of trusted white community members and aided in the landing of hundreds of Chinese in Portland.

In the end, 33 indictments were filed against 58 people. Witnesses, who testified for the state, including Nat Blum, H.T. Berg, and Robert Garthorne, were either released from prosecution or paid small fines for their role in the Blum-Wilson operation. William Dunbar was sentenced to two years in county jail and a $\$ 5,000$ fine. C.J. Mulkey, the collector of customs, received a sentence of one year in the county jail and a $\$ 5,000$ fine. James Lotan and Seid Back, both indicted on immigration smuggling, were found guilty and sentenced to heavy punishment. Both Lotan and Seid Back appealed their cases three times. Finally, in 1895, the men were found guilty on a reduced sentence. Lotan was fined $\$ 5,000$ and Seid Back $\$ 3,000$. Thomas (T.A.) Jordan and Herbert Adams, both minor players in the operation, were jointly indicted on two counts for smuggling opium. ${ }^{51}$ Major John Wilson was indicted on ten counts charging he smuggled opium, on various occasions, from

${ }^{51}$ The first count alleged that in January 1893 Jordan and Adams smuggled 500 pounds of prepared opium into the United States from British Columbia. The second count alleged that the men aided and abetted N. Blum in smuggling 500 pounds of opium in January 1893. Jordan was captain of customs inspectors and Adams was engineer of the steamer Wilmington. 
British Columbia to the United States. Because he was a Canadian citizen, however, the U.S. court system could not extradite him to the United States for trial. ${ }^{52}$ Most of the other Chinese defendants were released from the charges against them, and only two Chinese were indicted on perjury charges as interpreters for habeas corpus cases. ${ }^{53}$ Most of the men, both Chinese and whites, indicted and sentenced in U.S. v. Wilson went on to hold prominent positions in Portland and maintain those positions to the end of their lives.

${ }^{52}$ Wilson was charged with smuggling the following shipments of opium: July 1 , 1892, 300 pounds; July 12, 450 pounds; June 4, 365 pounds; October 28,500 pounds; November 26, 2,090 pounds; July 28, 300 pounds; August 20, 800 pounds; September $2,1,400$ pounds; January 27, 1893, 1,020 pounds; February 22, 1,100 pounds.

53 Louie Gow was indicted for perjury in a Chinese habeas corpus case tried before Referee Lafferty in November 1892. In the case, he claimed that he had known Louie Ah Fat for at least six years as a merchant in Portland. The court later judged that Louie Ah Fat was actually a first-time laborer attempting to enter the United States with a forged return certificate and false testimony by the Chinese witness. Charles Newell faced similar perjury charges after he swore in a habeas corpus hearing that he knew Wong Teong to be a member of the Foot Yie Company in Portland. Again, Wong Teong was a Chinese laborer. Daily Oregonian, Dec. 20, 1893. 


\section{Chapter Four}

Chinese Associations in Portland:

Unity and Division within Adapted Social Institutions

"The Highbinder Must Go!" screamed the headline of the Morning Oregonian on December 5, 1888.' Two days before, Chinese immigrant Mah Bing was shot fatally during a skirmish in front of Yuen Lee's gambling house in downtown Portland. Ah Seen, one of the few material witnesses who agreed to testify, said that he did not know who fired the shots that wounded Ah Ling, Wong Chung, and Lup Yick. Lup Yick, on the other hand, told local reporters a story that could have been taken directly from the pages of a popular gazetteer. He stated that Wung Woon fired five or six shots while Koon Dock fired down at him from above and Quin Chung Lung shot from within the store across the street from the gambling house. In the article, the author stated what might seem an obvious conclusion: "the Chinese fight of Sunday afternoon has stirred up considerable feeling not alone among the white people, but among the better class of Chinamen themselves."

While the Daily Oregonian responded to reports of violence in Chinatown, the majority population possessed little understanding of the social relationships behind this incident. Stories of violence between rival Chinese secret societies in the Daily Oregonian during the weeks following the shooting consisted of piecemeal reports about Chinatown's secret societies. Reporters compiled testimony from Chinese willing to share information, and the rest was filled in with popular stereotypes that

\footnotetext{
${ }^{1}$ Daily Oregonian, Dec. 5,1888 , p. 8.
}

${ }^{2}$ Ibid. 
had for decades shaped the public's understanding of Chinese immigration and-to whites- the mysterious institutions they had established within Chinatown. Like other reports written and read by whites, newspapers had a tendency to lump all Chinese associations into the category of "tong" or "secret society.".

In reality, first-generation Chinese social institutions in the United States need to be understood as three unique but overlapping organizations, with distinctive but overlapping goals and membership. As both the Chinese population and the complex web of Chinatown social institutions increased, conflicts arose for various reasons. Competition between rival social associations was at the root of many conflicts. Homeland rivalries transferred to the United States encouraged the alignment of Chinese along traditional lines of association. The desire to recruit members, and funds derived from membership fees, encouraged violent behavior. Competition for control of illicit trade only deepened internal conflict. By the turn of the century, collaboration between Chinese associations and white law enforcement officials severed the Chinese population into two camps, those who sought to resolve violence through mediation and those who furthered their goals through the use of violence. ${ }^{4}$

${ }^{3}$ English-language newspapers often reported on secret societies, which they also referred to as "White Lily Societies." Gazetteers both romanticized secret societies and sent fear into white readers who viewed the societies as a threat to the moral code of the majority population and a criminal element not easily suppressed through traditional policing. For more on Chinese secret societies and immigrants in Oregon, see, Oregon Historical Society, microfilm collections, Grant County News, West Shore, and the Daily Oregonian.

${ }^{4}$ See Linda Kay Strong, "Mutual Support Organizations of Northwest Chinatowns," Pacific Northwest Forum, 6 (1992), pp. 29-37; Douglas W. Lee, "Sacred Cows and Paper Tigers: Politics in Chinese America, 1880-1900," Annals of the Chinese Historical Society, 32 (1989), pp. 86-103; Eve Armentrout-Ma, "Chinese Politics in 
Portland's Chinese associations can be seen both as fitting into a larger historical context and as unique to this city, because of their independence from the centrally-based Chinese Six Companies of San Francisco. This chapter shows, first, how Portland's Chinese associations were transplanted to Portland from China, and how, in many ways, they resembled the structural framework of Chinese associations in other western urban enclaves. Second-and contrary to existing scholarship that places the Chinese Six Companies of San Francisco at the center of illegal activities on the Pacific Coast, such as illegal immigration, opium importation, and prostitution traffic - the chapter emphasizes the extent to which Portland's Chinese associations were dominated by local leaders. The Portland associations were not simply branches of the Chinese Six Companies based in San Francisco, but, instead, gained strength from localized activities, both benevolent and illegal in nature. Traditional social associations served as aid societies, operated illegal networks, and in some cases collaborated with members of the white community to further the goals of individuals and groups."

the Western Hemisphere, 1893-1911: Rivalry Between Reformers and Revolutionaries in the Americas," (Ph.D. dissertation, University of California, Davis, 1977), pp. 7681, 118; Yung-Deh Richard Chu, "Chinese Secret Societies in America: A Historical Survey," Asian Profile, 1 (1973), pp. 21-38.

${ }_{5}^{5}$ For interpretations on the role of the Chinese Six Companies in Chinese immigration, see Patricia Cloud and David Galenson, "Chinese Immigration and Contract Labor in the Late Nineteenth Century," Explorations in Economic History, 24 (1987), pp. 22-42; Charles J. McClain, Jr., "Chinese Immigration: A Comment on Cloud and Galenson," Explorations in Economic History, 27 (1990), pp. 363-378; Cloud and Galenson, "Chinese Immigration: Reply to Charles McClain," Explorations in Economic History, 28 (1991), pp. 239-247. 
Background: Chinese Associations and their Role in Portland's Chinese Enclave

As was the case in other Chinese communities in the American West, Portland's immigrant associations can be categorized into three primary groups: clan associations, district associations, and secret societies (or tongs). As Stanford Lyman wrote long ago, these three types of Chinese organizations were often lumped together in a single category by white Americans, especially newspaper reporters. ${ }^{6}$ In actuality, each of these groups provided distinct services to the Chinese immigrant community, framed their organization on social associations developed in China, and united members along lines of place of origin, name, and family relationships. Chinese associations were modified in the United States to confront challenges faced by immigrants. Associations also adapted their structures to take advantage of new opportunities and demands in the United States, such as trade in illicit goods and prostitution. Finally, each of the immigrant associations provided areas of autonomy for Chinese both within the immigrant enclave and from white outsiders who sought to control and reshape immigrants along western religious, cultural, and social lines.

Clan associations were the first of three social associations transplanted to the United States from China. Clan associations can be traced to family lineage communities of southeastern China. These associations based membership on a

'Stanford M. Lyman, The Asian in North America, (Santa Barbara: ABC-CLIO, Inc., 1970), pp. 103-119. See also Gunther Barth, Bitter Strength: A History of the Chinese in the United States, 1850-1870 (Cambridge, Mass.: Harvard University Press, 1964), pp. 28-29, 75-79, 80-87, 90-97,119-120; L. Eve Armentrout Ma, "Chinatown Organizations and the Anti-Chinese Movement, 1882-1914," in Sucheng Chan, ed., Entry Denied: Exclusion and the Chinese Community in America, 1882-1943 (Philadelphia: Temple University Press, 1991), pp. 147-169. 
shared surname and established identity and clan brothers on direct blood relationships. Chinese merchants served frequently as the leaders of clan associations. ${ }^{7}$ They assumed many of the duties previously held by lineage leaders in China and offered advice, and in some cases financial assistance, to members.

Storefronts owned and operated by merchants often served as living quarters for clan association members, and opportunities for social interaction often took place in these quarters. Rotating credit systems, operated by clan associations, served as jumping-off points for members who wished to open businesses and helped members to meet debts or purchase legal services. ${ }^{8}$

The second traditional Chinese association transplanted to the United States was the district association, or huiguan. As in China, district associations in Portland included individuals who shared a common geographic origin in China, spoke a common dialect, or belonged to a shared ethnic group. ${ }^{9}$ The district association, like the clan association, served as a credit and loan society and employment agency. Leaders of these groups commonly supported members financially in court cases by serving as. sureties. As the nineteenth century proceeded, district associations in

\footnotetext{
${ }^{7}$ Although records for clan associations in Portland are few, in eastern Oregon and southeastern Washington State, the Ing clan was particularly well known for its role in bringing family members to the United States to work in mines and on railroad projects. See Jeffrey Barlow and Christine Richardson, China Doctor of John Day (Portland, Ore.: Binford \& Mort, 1979), pp. 4-34.

${ }^{8}$ See, Sucheng Chan, This Bittersweet Soil: The Chinese in California Agriculture, 1860-1910 (Berkeley: University of California Press, 1986), pp. xxi, 5-6, 52, 292, 404. ${ }^{9}$ For more on traditional associations in China and their transplantation in the United States see Brynna Goodman, Native Place, City, and Nation: Regional Networks and Identities in Shanghai, 1853-1937 (Berkeley: University of California Press, 1995); Lyman, Chinese Americans (New York, 1974), pp. 29-53.
} 
Portland, and other urban enclaves united, eventually transforming into Chinese Consolidated Benevolent Associations (CCBA) in the early twentieth century. District associations, and eventually the CCBA, frequently supervised contract immigrant labor and provided an organizational basis for craft and merchant guilds. ${ }^{10}$ In many cases the leaders of district associations arbitrated conflicts between Chinese over such issues as gambling and district association rivalries transplanted from China to the United States. District association leaders also served as mediators during disputes between Chinese and whites, especially over labor contracting and labor performed. Members relied on the leadership, and in many cases, the English-language skills, of association leaders. The multi-faceted role provided by district associations and the ties of allegiance these associations embodied gave them substantial authority in Portland's Chinatown.

Finally, the secret societies, also called tongs or triads, created the third and perhaps best known (in the white community) Chinese immigrant association in nineteenth and early twentieth-century Portland. ${ }^{\prime \prime}$ Secret societies in the United States were derivative from the Chinese triad society and Freemason societies. As Stanford Lyman has explained, for centuries in China the secret society served as the

${ }^{10}$ Lyman, The Asian in North America, pp. 106-107.

"This chapter used the term "secret society" to describe the third type of Chinese association. Nineteenth-century newspapers and magazines frequently used the term secret society and "tong" or "triad" to describe Chinese associations engaged in illicit trade. The traditional character, and meaning, of "tong" however was used in average business names as well as to describe groups involved in illicit trade. Triad societies were perhaps the most famous of China's traditional clandestine associations and were synonymous with secret societies in U.S. Chinese immigrant communities. For ease of incorporating published material into the chapter, secret society will be used. 
principal agency of protest, rebellion, and banditry. They also provided a "haven for those who blamed officialdom for their agricultural or professional failures, or for those who had been expelled from their village, expunged from their lineage groups, or who had run afoul of the law." Additionally, secret societies in China often controlled the sale of illicit goods and services and provided occupations and avenues to upward mobility for those unable to achieve success through legitimate means. ${ }^{12}$

As large numbers of Chinese immigrants arrived in the United States in the 1850 s, so too did the secret society. By the late 1870 s, these secret societies soon controlled illicit enterprises-illegal immigration, prostitution, and gambling and opium dens. Although newspapers emphasized and sensationalized these activities, secret societies did in fact contribute to the well being of their members, altering the traditional model to fit the needs of an immigrant community that confronted persistent discrimination. For instance, secret society leaders funded the construction of religious and community buildings within Chinatowns, housed destitute widows and orphans, and provided financial assistance to members.

More so than the other two traditional associations, secret societies remained out of the sight of white Americans. Especially after the crescendo of anti-Chinese laws in the 1880s and 1890 s, clan and district associations often united publicly and visibly in the courts and in politics to contest discrimination. Secret societies, on the other hand, did not seek to alter, oppose, or challenge anti-Chinese legislation, focusing instead on internal political, social, and financial conditions within

${ }^{12}$ Lyman, The Asian in North America, p. 48. 
Chinatown, and the organization of illicit trade networks. Secret societies were frequently composed of Chinese who had been ostracized by Chinatown's clan and district associations. Economically, the societies met financial goals through the opium trade, prostitution, and the operation of gambling houses throughout

Chinatown. Through these enterprises, secret societies gained substantial political and social influence, as well as economic power, in the Chinese enclave. The fact that many members were toughs and thugs only increased the degree of control secret societies held. ${ }^{13}$

Traditionally, four main motives prompted secret societies and their henchmen; control of the drug trade, gambling, and prostitution; the sometimes violent playing out in the United States of Chinese social conflict; revolts of poor Chinese against the merchant oligarchy of Chinatown; and rival claims to a woman. ${ }^{14}$ Orchestrated "tong wars" between rival secret societies served as the avenue through which these battles played out, and it was these "wars" that gained so much attention on the part of English-language newspapers and the police.

${ }^{13}$ Originally found in Barkerville, British Columbia, a collection of rules of a Chinese secret society illuminates the experience Chinese immigrants involved in a secret society. Broken down into 42 regulatory rules and further divided into three broad sections, the document, written sometime around 1882 details fiscal policies, rights, privileges, and responsibilities of members, and the relationships between mutual aid societies and members. Protection by fellow members was afforded those who were assaulted from within or without the society and punishment for violence against members was also detailed. See W.E. Willmott and Berching Ho, "Rules of a Chinese Secret Society in British Columbia," in Lyman, ed., Asians in North America, pp. 95102.

${ }^{14}$ Lyman, The Asian in North America, p. 110. 
Toward a Theory of Localization: Labor, Illicit Trade, and Violence among Portland's Chinese

These three traditional social associations were well established in Portland's Chinese community by the 1880 s. The decade was also marked by anti-Chinese labor agitation and the enactment of immigration laws that directly hindered the ability of Chinese to immigrate to the United States or to find jobs once there. As employment collapsed in rural areas dominated by mining, logging, and railroad building, Chinese migration to the cities increased. Competition for jobs in the cities, Portland included, became intense, producing frustration and violence in Chinatown. ${ }^{15}$

Many historians have studied the affects that anti-Chinese laws and the urbanization of Chinese had both on individual immigrants and the traditional social associations in urban hubs as a whole. The Chinese Six Companies of San Francisco, for example, are cited frequently to demonstrate the changing roles traditional associations played during the era of exclusion. ${ }^{16}$ On this point, historians have established the influence the branches of the Six Companies had on illegal immigration and the organization of contract labor during the 1880s and 1890s in urban areas outside San Francisco. And while this branching out on the part of the

${ }^{15}$ See Chen Tzu Wu, ed., Chink! A Documentary History of Anti-Chinese Prejudice in America (New York, 1972); Shih San Henry Tsai, The Chinese Experience in America (Bloomington, Ind.: University of Indiana Press, 1984); Tsai, China and the Overseas Chinese in the United States, 1868-1911 (Fayetteville, Ark.: University of Arkansas Press, 1983).

${ }^{16}$ See especially, Cloud and Galenson, "Chinese Immigration and Contract Labor," pp. 22-42; McClain, "Chinese Immigration: A Comment on Cloud and Galenson," pp. 363-378; Cloud and Galenson, "Chinese Immigration: Reply to Charles McClain," pp. 239-248. On urbanization and crime among Chinese immigrants See, Paul Takagi and Tony Platt, "Behind the Gilded Ghetto: An Analysis of Race, Class and Crime in Chinatown," Crime and Social Justice, (1978), pp. 2-23. 
Chinese Six Companies surely occurred, emphasis on its San Francisco base obscures understanding of how local associations altered their roles on the local level to fit changing circumstances. ${ }^{17}$ When we shift perspective and look more closely at local associations, it is apparent that they provided the structure of everyday life in the Chinatowns of the West. This was surely the case in Portland.

Three aspects of Chinese society in Portland demonstrate this theory of localization. First is the way in which labor contracting, employment, and the procurement and repayment of debts gave shape to Portland's Chinese associations in the 1880s. These associations became the mainstay of the community; association leaders fused traditional Chinese forms of mediation with U.S. court intervention. Second, associations were at the center of the local labor market - and the conflicts that ensued over work in the $1880 \mathrm{~s}$. Third, this chapter examines conflict between Chinese associations and shows how organized crime in Chinatown hinged on local competition between Portland associations as well as conflict between Portland

${ }^{17}$ References to the Chinese Six Companies' role in immigration, both legal and illegal, did show up in English-language newspapers. In December 1893, for instance, the Daily Oregonian, reporting on the implementation of the Geary Law (which further restricted Chinese immigration to the United States and required Chinese immigrants already here deported if they did not file for resident certificates), reported, "It is believed that if the government shows that it intends to deport all unregistered Chinese, the Six Companies will take notice accordingly, and assist instead of retarding the operation of the law." Adding to this story, local Chinese immigrant Seid Back remarked, "My countrymen will abide by the decision of the Six Companies, of course." Stories similar to these documented that the Chinese Six did play a role in legal immigration to the United States, but few reports speak directly to a notable presence of the Chinese Six in Portland or their involvement in smuggling cases tried in Portland. Rather, these were operations run by local Chinese, merchants especially, who had a stake in immigration and opium trade networks. See the Daily Oregonian, Dec. 1, 1893, p. 4. 
Chinese and branch representatives of the San Francisco Chinese Six Companies. By framing the history of Chinese associations in this way, it is possible to see how the power of the secret associations was in fact highly localized, a product of Portland, not San Francisco. While similar to those in San Francisco, the secret societies of Portland were by no means dependent on them.

Labor Contracting, Debt Procurement, and Legal Conflict in the Chinese Community In Portland, as in San Francisco and other Pacific Coast cities, district associations, or huiguan, served as innkeepers for traveling Chinese laborers, credit and loan societies, and employment agencies and labor contractors. As Chinese flooded into Portland after rural labor opportunities dissolved, the services provided by Portland's district associations changed, and their power within the community increased. As many historians have noted, a primary function of the district association was the provision of financial assistance based on a rotating credit system. $^{18}$ In this system, members of district associations were loaned money to be repaid with interest after a specified period of time. When members failed to repay their debts promptly, and internal mediation failed, district associations went to court to collect.

In July 1884 , such a case occurred. In that month, Wong Doon brought members of Fing Lung and Company to court for failure to repay a loan of $\$ 1,533$. The load was originally granted in the fall of 1883 and, in keeping with district

${ }^{18}$ See, Lyman, Asian in North America, pp. 103-118. 
association rotating credit regulations, was to be repaid by February 1884 at an interest rate of eight percent per annum. After being late a mere five days, Wong Doon, with sureties King Chow, Dock Wa, and Luck Wa, applied for a writ of attachment against the property of the Fing Lung and Company. ${ }^{19}$ In a similar case, Chin Chun Ban brought Yuen Chong and Company to court after district association members Chin Chun Ban and Chin Chow Chin loaned the defendants $\$ 1,400$ and $\$ 500$ respectively. When the loan was three months overdue, the plaintiffs concluded that mediation had failed and forced the association into the U.S. circuit court. This pattern defines scores of cases, attesting to Chinese district association leaders using the courts regularly to resolve conflicts over loans. The arrangement and uniting of various Chinese in multiple court cases show how members of credit systems, and inevitably, district associations that controlled substantial amounts of capital, used their funds to assist needy Chinese who shared membership in district associations. In many instances the cases were dismissed, and the two parties settled outside of court—the initial threat of court action was apparently sufficient to force repayment. ${ }^{20}$

Another case in the Multnomah County District Court involved an individual who was loaned funds by various district association members and then failed to repay the debt. In June of Gim Fook, Dick Fong, Sam Nam Lou, and Lai Nam Lou brought Sam Lee to court after he failed to repay $\$ 2,450$ in loans. Gim Fook had loaned Sam Lee \$1,050, Dick Fong loaned \$700, Sam Nam Lou loaned \$150, and Lai Nam Lou

${ }^{19}$ Wong Doon v. Fing Ling and Co., Judgment \# 12294, July 15, 1886. 
loaned Sam Lee $\$ 550$. The plaintiffs won their case with a final settlement of $\$ 2,450$ plus court costs. ${ }^{20}$

By the 1880 s a strong merchant elite, under the auspices of district associations, gained control of Portland's labor contracting services. ${ }^{21}$ Merchant leaders of district associations who operated stores and contracting companies used their understanding of the courts and American business to defend Chinese immigrants in court. Merchants signed contracts with whites and supplied Chinese bosses and labor gangs to logging and railroad companies throughout Oregon and beyond. Under these contracts, whites would pay the Chinese contractor after labor gangs finished work. The Chinese contractor, almost always a merchant, would then pay the Chinese men who served on the work gangs. Inevitably, labor contracting produced conflict, especially when employers refused to pay Chinese laborers for their services.

In January, 1893, Gai Kee brought J.S. and C.C. Miller to court after the latter failed to pay the plaintiff $\$ 432.50$ for the labor of two gangs of ten Chinese workers contracted to cut 2000 cords of wood for the Oregon and California Railroad. The plaintiff testified that C.C. Miller paid him $\$ 87.50$ after the first gang of laborers finished their work in Milwaukie, Oregon, but failed to pay the remaining $\$ 432.50$ for the second gang's work. In court, Gai Kee submitted a copy of the labor contract (written in traditional Chinese characters) as evidence. In response, J.S. and C.C. Miller testified that the second gang of laborers failed to complete the contracted

${ }^{20}$ Gim Fook v. Sam Lee, Judgment \# 10059, June, 13, 1884.

${ }^{21}$ Sucheng Chan reaches a similar conclusion in her study of Chinese immigration in California's Sacramento Valley. See, Chan, This Bittersweet Soil, pp. 368-370. 
work. But, in the end, the Chinese plaintiffs won their case and an additional $\$ 200$ for court costs. Indeed, many labor contracting cases ended favorably for Chinese labor contractors. Their success turned on the financial and testimonial support of district association members, who paid lawyers' fees and testified in favor of Chinese plaintiffs. Over the years, the fusion of merchant elites and labor contractors and district association members proved essential in many cases brought against whites. ${ }^{22}$

Not only did Chinese associations bring whites to court on the grounds of broken contracts, they also brought to court fellow immigrants who served as middlemen for white-owned companies. Chinese labor contractors often struggled with these Chinese labor brokers when the latter delayed payments or refused to pay altogether. Chinese labor brokers and bosses were central to the contracting system, serving as interpreters during contract negotiations and in the labor camps as well. As two court cases from 1881 and 1883 demonstrate, agreements between Chinese labor contractors and their middleman counterparts could be ridden with conflict, and in the ensuing conflicts the district associations played critical roles. ${ }^{23}$

${ }^{22}$ See, Gai Kee, J.S. and C.C. Miller, Judgment \# 19697, Jan., 1893; Chung Lung v. James Cooper, Judgment \# 7614, Jan., 1881. Chinese labor contractors also provided provisions for laborers who were sent out in gangs to work for white-owned companies. In another case tried in Multnomah County Circuit Court, the Hop Chung company sued J.C. Todd and J.F. Biven of Todd \& Biven for goods sold and delivered to a labor site. The plaintiffs claimed that they delivered 400 mats of rice to the site in the spring of 1883 . The aggregate cost of these shipments was $\$ 885$, and the Chinese labor contractors eventually won their case in the sum of $\$ 803.05$.. See Hop Chung and Company v. Todd \& Biven, Judgment \# 9192, June 11, 1883. 
In 1881, Kwong Loon Kee and members of his company, Ah Top, Ah Kam, Wong Tuck, and Ah Looey, together sued the C.Y.S. Sprague Company. ${ }^{24}$ Their complaint held that the white-owned company failed to pay $\$ 900$ for providing 200 laborers to clear railroad track between the Sandy River and the Dalles, Oregon. In addition to the C.Y.S. Sprague Company, the Kwong Loon Kee Company sued the Chinese middleman, Ah Sam, who had coordinated the original agreement. The Kwong Loon Kee and Company won the case for the sum of $\$ 900$. In a similar case, Chinese labor contractor Lee Chew sued Wing Hing Chewey for failing to pay thirty or so Chinese laborers for their work for the Oregon Railroad and Navigation Company. ${ }^{25}$ Again, the court judged that the Chinese middleman had failed to uphold the contract signed between the Chinese contractor and white-owned company. Lee Chew and his associates were awarded $\$ 197$ and court costs. In these cases, merchant elite contractors aligned themselves financially with one another to fight breach of contract cases against whites and Chinese middlemen and were thereby able to pay Chinese laborers the money due for their work. ${ }^{26}$

These cases are significant in two respects. First, they show how Chinese were active in court cases against whites on a regular basis. Chinese labor contractors and

${ }^{24}$ In this case, Chin Loong signed as surety up to $\$ 2000$, and the district association members and co-owners mentioned above served as witnesses. See Kwong Loon Kee and Company v. C.M.S. Sprague, Judgment 7736, Feb. 18, 1881.

${ }_{25}$ Lee Chew v. Wing Hing Chewey, Judgment 9038, May, 1883.

${ }^{26}$ In this case, Lee Chew brought Wing Hing Chewey to court independently. Once underway, the Chinese labor contractor and Chinese defendant aligned themselves with wealthy merchants like John Wah, who signed as surety for the defendant, thereby agreeing to pay all court costs for the defendant. In cases such as this, court costs would likely have been too great for individual Chinese to meet. Social and financial support was crucial to Chinese plaintiffs and defendants alike. 
merchants were not afraid of suing wealthy white companies as well as fellow

Chinese. It is often assumed that Chinese did not stand a fighting chance in court against whites, but in fact not only did Chinese do so frequently, they employed powerful social and financial institutions transplanted from China in these cases and often won.

Furthermore, Chinese middlemen who aligned themselves with whites--and thereby against Chinese district associations and the merchant elite-fared less well. Because they aligned with whites, they were marginalized by Chinese social associations and always subject to the power of the labor contractors and their fellow district association members. For instance, in the Kwong Loon Kee case, the Chinese plaintiffs aligned with two wealthy outside Chinese merchants who assured financial, legal, and community support within Chinatown. But the Chinese middleman, Ah Sam, had no such allies. Instead, he had only a tenuous business connection to a white company, which likely viewed him as useful only as a supplier of cheap labor.

Eventually, these connections-or in the case of Ah Sam, lack of Chinese connections-determined the outcomes of many cases.

Secret Societies, Their Activities, and Change over Time: Patterns of Localization in The $1880 \mathrm{~s}$

Historians have studied the development of Chinese associations in the United States, focusing on the Chinese Six Companies of San Francisco and their connections to other Chinatowns in the American West. The Chinese Six Companies represented a 
coalition of the six primary district associations that were transplanted to North America during the earliest years of Chinese immigration. ${ }^{27}$ Historians Stanford Lyman and Gunther Barth have shown that the Chinese Six Companies, in San Francisco were a centralized unit that dominated labor contracting, the traffic of illegal immigrants, prostitution, and gambling. While Lyman and Barth describe the role of the San Francisco Chinese Six in immigrant communities throughout the West, they fail to show how the internal power structures of Chinese communities outside of San Francisco were, in their own right, structured. The Chinese associations in Portland, understood as distinct organizations, wielded influence and power on the local level distinct from that of the San Francisco Chinese Six.

This local structure of power is best illustrated by Portland's secret societiestheir activities, membership, and internal conflicts, as these were documented in newspaper articles and court cases. As Gunther Barth wrote in Bitter Strength: A History of the Chinese in the United States, 1850-1870, Chinese secret societies often hid their illegal activities (prostitution rings, gambling, and opium and immigration

${ }^{27}$ Lucy Salyer and Charles McClain have been particularly thorough in their research of the role played by the Chinese Six Companies during the early years of exclusion. Before 1882, the Chinese Six Companies had primarily an internal community focus, addressing issues that occurred within the Chinese community rather than involving themselves in state or national politics. However, with the advent of Exclusion, the Chinese Six Companies organized large-scale campaigns to fight exclusion directly. See Lucy Salyer, Laws Harsh as Tigers: Chinese Immigration and the Shaping of Modern Immigration Law (Chapel Hill, N.C.: University of North Carolina Press, 1995); Charles J. McClain, In Search of Equality: The Chinese Struggle Against Discrimination in Nineteenth-Century America. (Berkeley: University of California Press, 1994). 
smuggling) behind a façade of benevolent activities. ${ }^{28}$ By the $1860 \mathrm{~s}$, Portland's

Chinese secret societies were providing the city's predominantly male Chinese population with prostitutes, opium, and gambling houses as well as housing and loans. Secret society henchmen, often referred to as "highbinders" or "hatchetmen," provided protection for their societies' leaders and for each other (and for their society's illicit activities). In the 1880s, English-language newspapers frequently reported on violence and confrontations between secret societies and sensationalized the activities of so-called "highbinders," who in essence were the society's soldiers. Like the Six Companies of San Francisco, Portland's powerful secret societies frequently battled each other for control of Chinatown vice. Rivalries to control the prostitution trade and illegal immigration was particularly intense from the 1880 s forward.

\section{Prostitution}

The problem of prostitution in Portland's Chinatown was discussed by the city's council as early as 1859 . To whites, Chinatown prostitutes represented a particularly depraved class, lower than white prostitutes, even, because, unlike their white counterparts, the Chinese were believed to have been sold into their profession by poor Chinese families. They were of the lowest class, unable to reform themselves after male Chinese immigrants purchased them. Among the male Chinese immigrant community, Chinese prostitutes represented something else. First, they provided the men with sexual relations in an overwhelmingly male society; second, as business

${ }^{28}$ Barth, Bitter Strength, 77, pp. 101-102. See, also, Lyman, The Asian in North America, pp. 86-92, and Yung-Deh, "Chinese Secret Societies in America," pp. 21-38. 
commodities, they represented opportunities for profit. Heated competition between operators of prostitution houses and prostitution rings was the result, and this intraChinese competition was often played out in the press. As early as 1859 , for example, a group of Chinese men asked the Portland city council to rid Chinatown of prostitutes, and in December, 1861, the Daily Oregonian reported that competition to control Chinese prostitution in Portland was headed towards violence. Often, one district association charged another with keeping a bawdy house and threatened to close it down or, in some case, take it over. Judging by the press, whites feared the bloody fights between secret societies in the Chinese enclave that broke out after such battle cries were called.

By the 1880 s, secret societies and Chinese organizations engaged in what seemed a constant struggle over control of prostitution in Portland's Chinatown. Arrests increased noticeably during the decade, partly because of new city ordinances that required checks on bawdy houses within city limits. ${ }^{29}$ In addition, Chinese men increasingly accused one another of keeping Chinese prostitutes and demanded that police raid the houses. In all likelihood, what was happening was that Chinese accused one another in order to shut down competitors and gain control of the business. The consequence of this competition was a focus on Chinatown prostitution

${ }^{29}$ The Oregon legislative assembly instituted the "bawdy house" law in 1864 , which stated, "If any person shall keep or set up a house of ill-fame, brothel, or bawdy house, for the purpose of prostitution, fornication or lewdness, such person, upon conviction thereof, shall be punished by imprisonment in the county jail, not less than three months, nor more than one year, or be fined not less than one hundred dollars, nor more than five hundred dollars." See, Charles A. Tracy, "Race, Crime and Social Policy: The Chinese in Oregon, 1871-1885," Crime and Social Justice, (1980), pp. 1416. 
by the authorities, increased raids on bawdy houses, and constant arrests, although seldom followed by prosecution. ${ }^{30}$

It appears from court records that, when Chinese immigrants brought others to court for keeping prostitution houses, the primary conflict was over which group would control prostitution; concern for women seldom appeared to be at issue. Instead, men aligned with other members of their respective associations and accused members of competitor associations of keeping houses of prostitution or keeping women against their will in these houses. Hidden behind a veil of moral concern, these cases appeared frequently in the district and circuit courts under the auspices of writs of habeas corpus. For instance, in July 1884 Lee Sheng accused another Chinese immigrant, Wong Ah Tong, of holding Cheng Moy against her will at "No. 147, $2^{\text {nd }}$ street on the third story." Lee Sheng sought a writ of habeas corpus to free her from captivity, pleading that "Cheng Moy is so restrained of her liberty to be used as an inmate of the defendants' house of prostitution and against her will and protest." Although this case eventually was dismissed, it was a representative instance of one association, Lee Sheng's, allying against another, Wong Ah Tong's. ${ }^{3 !}$

${ }^{30}$ In many respects, police raids on bawdy houses, and Chinese prostitution houses particularly, were used to quell public complaints. Generally, Chinese prostitutes were arrested en masse, tried on misdemeanor charges, and fined five dollars. They quickly returned to the Chinese quarter to continue their trade. See State of Oregon v. Ah You, Judgment \#10212, July 1, 1884; State of Oregon v. Lang Ah Bing, Judgment \#10214, July 1, 1884; State of Oregon v. Ah Ming, Judgment \#9981, May 17, 1884 and July 3, 1884; State of Oregon v. Lee Moy, Judgment \#10216, July 3, 1884, Multnomah County Circuit Court, Multnomah County Courthouse Files Room. ${ }^{31}$ Lee Sheng v. Wong Ah Tong, Multnomah County Circuit Court, May 1884, Judgment \# 10223, Multnomah County Courthouse Files Room. In a similar case, different associations aligned with one another for and against Moy Youk. In this 
As in other Pacific Coast Chinatowns, in Portland wealthy merchants often

headed the secret societies that competed for control of prostitution networks.

Frequently, police officials were bribed to turn a blind eye to prostitution dens. When raids did occur, many judges also turned a blind eye to the testimony of Chinese witnesses accusing one another of keeping houses for prostitution. ${ }^{32}$ Cases were dismissed as judges decided that the men accused, and the women restrained, were not convictable under city or state statutes despite anti-prostitution laws at both the local and state levels. ${ }^{33}$ Indeed, in the $1880 \mathrm{~s}$, rather than prosecute alleged brothel owners,

case, Ah Young, Ah Sing, and Ah Hin testified in court that Moy Youk operated a "house of ill-fame" on Stark Street between Second and Third Streets. After the judge dismissed the case on the grounds that the state could not validly make claims against the Chinese owner of the house, the complainants likely took their dispute outside of the courts. Other cases involving associations and prostitution, include State of Oregon v. Ah You, Judgment \#10212, July 1, 1884; State of Oregon v. Lang Ah Bing, Judgment \#10214, July 1, 1884; State of Oregon v. Ah Ming, Judgment \#9981, May 17, 1884 and July 3, 1884; State of Oregon v. Lee Moy, Judgment \#10216, July 3, 1884, Multnomah County Circuit Court, Multnomah County Courthouse Files Room. ${ }^{32}$ Prostitution-related arrests were low compared to the number of bawdy houses in Portland between 1870 and 1885 . Between 1870 and 1880 under Police Chief James H. Lappeus, only 16 persons were arrested for prostitution; eight were Chinese. Between 1877 and 1879, Chief of Police Lucerne Besser arrested 60 persons for prostitution, twenty-nine of whom were Chinese. Between 1879 and 1883, Besser arrested forty-two, twenty-nine of whom were Chinese, remarkably low numbers considering Portland was reported to have thirty "bordellos" in 1880. See Tracy, "Race, Crime and Social Policy," p. 15.

${ }^{33}$ Details on dismissed cases are spare. Generally, records simply state that Chinese testimony, both male and female, was not admissible. The cases were tried and quickly dismissed with neither side receiving fines or official charges. Racism against Chinese likely tainted these cases. Judges, and the public at large, regularly saw Chinese men who brought others to trial on prostitution-related charges as doing so out of a competitive drive to control prostitution and not out of concern for Chinese prostitutes. Finally, disinterest in prosecuting prostitution generally, and Chinese prostitutes and bawdy-house owners particularly, surely played a role in the frequent dismissals. Judges apparently turned a blind eye to the 1875 Page Act, which stated 
Mayor Thomas Holmes and other local officials called instead for a tax on Chinese bawdy houses and the removal of these houses from visible (to whites) areas between Morrison and Alder on Second Streets. Whites, fearful of Chinese unrest and the presence of Chinese outside of Chinatown, encouraged the city council to tax, rather the prosecute, men who ran houses that catered to the sexual needs of Chinese immigrants.

These steps did not, however, stop conflict over prostitution. Nor did they discourage the cross-border trade in prostitution between Oregon, California, and Washington. In fact, by the 1890 s Chinese highbinder societies had branched out, including in some cases white officials who aided the transport of Chinese prostitutes across state lines. A February 1893 District Court case concluded with the conviction of a white store owner from Seattle, David W. West, and a Chinese highbinder and secret society member, Ah Luie. Witnesses in the case testified that the woman at issue, referred to only as Mrs. Wing, was taken from Portland at the insistence of a highbinder who wanted to gain possession of her for commercial purposes. ${ }^{34}$

Prosecuting attorney Cecil Holcolm argued that Ah Luie and his secret society associates "did not hesitate to use the courts as a machine in order to attain their object," that being the cross-border sale of prostitutes to both white and Chinese customers. ${ }^{35}$

that Chinese women who came to the United States as prostitutes, as well as those already in the country, could be deported.

${ }^{34}$ Daily Oregonian, Feb. 16, 1893.

${ }^{35}$ Ibid. 
Gambling, Smuggling, and Illegal Trade in Goods

Prostitution networks were not the only areas of conflict among secret societies in Portland's Chinatown. Infighting between associations over a range of issues often produced heated battles and, sometimes, fatalities. Reports of bloody battles between clan and district associations and Chinese secret societies dot U.S. newspapers in the late nineteenth and early twentieth centuries. From these reports it is possible to reconstruct the reasons behind these battles as well as the ways Chinese aligned with one another to defend different interests. Two conflicts in Portland that took place between 1888 and 1890 show how the Chinese community mediated violence within the immigrant enclave by adapting the practices of transplanted Chinese associations and compromising with white law enforcement officials. In the process, these immigrants further reshaped class and status in Chinatown and produced new versions of traditional Chinese associations.

Secret Societies and Conflict in Portland

In many regards, Portland's network of traditional Chinese associations was part of a larger trend in Pacific Coast Chinese immigrant communities. Chinese organized themselves around a framework of associations based on status and geographic origins in China, governed by merchant elites whose power derived from economic success in West Coast Chinatowns. ${ }^{36}$ English-language newspapers frequently used the terms "secret society" and "highbinder" to describe the groups

${ }^{36}$ See Chapter Three for collaboration between Chinese and whites in both legal and illegal business activities. 
involved in Chinatown violence. For instance, an 1890 Daily Oregonian article reported on a series of violent outbursts that had the headline, "Chinatown Up In Arms, Another Bloody Highbinder Riot Anticipated., ${ }^{37}$ But what constituted a highbinder most whites could not say. As one reporter put it:

Highbinder really has no place in the English language. The dictionary and encyclopedia both fail to recognize it. It is a term like many others in the English language, colloquialized, and has acquired a standing through custom and usage. It is a conventional term, the same as "hobo," "hoodlum," and many others that have acquired a significance through a specified designation of some peculiar attribute of a general class. ${ }^{38}$

For those Chinese, or "highbinders" involved in secret society and district association rivalries, however, the term, and the role highbinders played, was quite clear. A highbinder was a member of a secret society and often served as the henchman in attacks on rival secret societies. Competition, and the perpetuation of violence in the name of revenge, developed into ongoing battles that sometimes spanned many years. Increasingly, powerful merchant leaders who saw themselves as permanent residents with distinct local interests stepped in to mediate conflicts between secret societies. By the late 1880 s, these merchants unified with whites to end Chinatown violence.

${ }^{37}$ Morning Oregonian, Aug. 15, 1890, p. 8.

${ }^{38}$ Ibid., Dec. 14, 1888, p. 3; See also, Ibid., Dec. 3, 1888. 
On December 3,1888, a battle began in Chinatown that would play out in newspapers and the courts for months to come. Repercussions from this initial conflict would eventually replay themselves in 1890 . The Daily Oregonian report on the initial battle described it as "the most sanguinary shooting affray which has ever occurred in this city.",39 The battle involved between fifteen or twenty Chinese men and ended with four Chinese immigrants dead and two seriously injured. From first reports, the battle was four-fold: Mah Bing stated that Wong Sing shot him over a gambling debt; Ah Lung claimed Pon Long shot him; Ah Sue claimed he was shot by Ah Lung; and finally Wong Chung testified that Mah Bing had been hit with a hatchet over the head and shot in the back by an unknown party. Mah Bing died of wounds sustained in the fighting, and the other three men and a fourth, Lup Yick, were brought to Good Samaritan Hospital, where they received treatment for their wounds.

The December battle began when two rival secret societies came head to head over control of gambling in Chinatown. In the months before the battle, a newly established secret society, referred to as the Hop Sing Hong, had begun collecting members, weapons, and officers in an attempt to gain control of Chinatown's gambling dens. Headed by Pon Long, the society frequently met in the restaurant of the principal officer in the Hop Sing Hong, Frank Woon. On the other side of the rivalry was the Bow Lung society, whose members controlled much of the gambling in Portland's Chinatown before the establishment of the Hop Sing Hong society. The

${ }^{39}$ Ibid., Dec. 5, 1888, p. 8. 
men involved in the case were members of one or the other of these societies. Mah Bing and two others belonged to the Bow Lung society, while Ah Sue and one other wounded Chinese man not identified by name, belonged to the Hop Sing Hong society. $^{40}$

In later interviews with a Daily Oregonian reporter, some of the more prominent merchants of Chinatown discussed the origins of the December 3, 1888 confrontation. According to them, the fight was the outcome of a rivalry between the two leading highbinders that controlled Chinatown's gambling and prostitution networks. By the late 1880 s there were five prominent secret societies in Portland. They were, in order of their original establishment, the Hip Sing Hong, Sue Sing Hong, Boo Leong Hong, Hung Sing Hong, and the recently formed Hong Sing Hong. Like secret societies elsewhere, these societies exacted tribute money by threat, bribe, and extortion, and from gambling houses, houses of prostitution, and immigrant and opium smuggling. At the time of the 1888 battle, the Boo Leong Hong numbered about one hundred members and the Hop Sing Hong counted three hundred members. $^{41}$

The competition to control illicit Chinatown businesses was complex, and in it Portland Chinese aligned according to their local association ties, used the U.S. legal

${ }^{40}$ Mah Bing, 30 years old and without family in China, died from a pistol shot in the Portland City Jail on December 4, 1888. Ah Sue also died days after the fight. Wong Sing, one of the accused, was never apprehended after the shooting; See, Ibid., Dec. 5, 1888.

${ }^{41}$ Ibid. 
system, and took direct action in the streets of Portland to resolve conflicts. ${ }^{42}$ In the weeks prior to the December 3 battle such a situation occurred. It began, like so many of these cases, in a seemingly simple manner. Chin You of the Boo Leong Hong society and Wong Lock of the Hop Sing Hong society were playing a game of dominos. When Chin You lost and refused to pay the two-dollars owed to Wong Lock, fellow members of the Boo Leong Hong-Mah Bing, Ah Bing, and Lum Geeall sided with fellow member Chin You's refusal. The rival gangs fought, and Mah Bing had Wong Lock arrested on charges of assault and battery. Wong Lock countered, filing the same charge against Chin You and Mah Bing. The judge convicted each of the men on the charges, fined each five dollars, and released them.

The following day, the two parties met again. A second altercation occurred, this time at the corner of Second Avenue and Alder Street. During this second fight, Wong Lock, along with fellow Hop Sing Hong members Ching Mow and Ow Low, fought members of the Boo Leong Hong society. Again, the men were arrested, fined various amounts for assault and battery, and released. But the conflict simmered. Over the following days, the Boo Leong Hong society attempted to reach a compromise with Wong Lock and his Hop Sing Hong society by paying the two dollars under dispute. But this had become something more than a dispute over petty gambling debts between individuals. Association was pinned against association in a struggle for predominance in Chinatown. So, despite the two societies' agreement to

${ }^{42}$ Numerous cases found in the archives of the Multnomah County Circuit Court attest to such cases with most ending in minor fines to those involved. 
settle the debt, the Boo Leong Hong society continued the feud, threatening "If you want to be boss come and have a fight with us and see who are the best men." ${ }^{, 3}$

For white policemen trying to sort out this conflict, one of the greatest challenges was getting Chinese to testify against one another. As one Chinese Portlander stated to a reporter, it was not that Chinese did not know who was responsible for the violence but that they would not tell for fear that they would be targeted by the accused society members. Another Chinese immigrant warned, "Don't mention my name in the paper for if you do the highbinders will come around and kill me." ${ }^{44}$ Testifying against members of rival secret societies involved a genuine risk, one few Chinese were willing to take. But Chinatown residents were not completely silenced; support for intervention by the police escalated along with the violence. As one Chinese said, "the city authorities ought to send eight or ten policemen to make a thorough search of Chinatown. There are still quite a number of wounded Chinamen hidden and if they are not soon hunted up they will either sneak out of town or get well without medical attendance." 45

In the days and months following the December violence, a clear division developed within the Chinese community. Merchants with a stake in Portland, men who, planned to stay permanently in the city and raise their families there, began to speak out. The developing alliance against violence did not follow those of preexisting Chinese associations. Instead, they followed lines of class and status

${ }^{43}$ Comments were collected by reporters for the Morning Oregonian and were printed in the December 4, 1888 edition.

${ }^{44}$ Ibid.

${ }^{45}$ Ibid. 
regardless of race; Chinese merchants, especially, and even those that belonged to district associations, viewed the violence of secret societies as dangerous to their personal interests, both in the white and Chinese communities, and generally disruptive to the future of the Chinese in Portland. For them, peace was associated with community success, and violence was equated with the continued distrust of the dominant white population. Along with the violence of the 1880s and 1890s arose a new desire to mediate violence in Chinatown and, even, to collaborate with white authorities to this end.

Newspaper reports highlighted some of the more outspoken members of the Chinese community who opposed secret societies. One prominent Chinese complained to the Daily Oregonian that part of the reason for the conflicts between Chinese secret societies was the fault of white law enforcement, that their failure to charge, arrest, and convict those responsible for illegal crime and violence in Chinatown allowed such activity to continue:

The laws in this country ... are altogether too lax for the Chinamen. This fight is a natural outcome of the leniency shown the Chinese murderers in the county jail. The Chinamen here have no fear for the law and think that they can buy their freedom if they have plenty of money. No such highbinder societies are allowed in China. If there are any secret organizations of any kind discovered in China they are more summarily dealt with. ${ }^{46}$

\footnotetext{
${ }^{46}$ Ibid. A later article built on these comments and detailed the various mechanisms used in various Chinese cities to ferret out violent secret societies. See the Morning Oregonian, Dec. 14, 1888, p. 3.
} 
Testifying in a similar vein, another stated that the Chinese secret societies could easily identify the guilty parties in every Chinatown fight, but that the more efficient solution would be for white authorities to break up the highbinder societies "and the police authorities must be more stringent if the community desires to have no recurrence of such a bloody fight.",47

The division within Chinatown was noted by white authorities. Shortly after the December 1888 battle, Portland's mayor appointed four special officers to patrol Chinatown. He also agreed to a meeting between white authorities and prominent Chinese merchants who wanted to quell the violence. Out of this came a new collaboration between whites and Chinese, one that testified not only to changes in Chinatown but also to the emergence of a Chinese elite and its ability to draw on resources outside the Chinese community. In meetings that followed, Mayor Van B. DeLashmutt and the Chief of Police Parrish met with Seid Back and other prominent Chinese merchants. The former announced: "Your highbinders are composed of the worst class of your people and are of no more benefit to you than our tramps or bags are to us. We want you to help us to break them up, and get the city rid of them." According to the Daily Oregonian reporter present at the meeting, Chinese merchants agreed with the Chief of Police's sentiment "it is to your interest as business men and 
law-abiding citizens of Portland to help us carry on this work and rout out every highbinder in this city.,48

What followed was a collaborative effort between whites and high-status Chinatown merchants to suppress the secret societies. The coalition placed posters printed in Chinese characters throughout Chinatown describing the agreement reached between Chinatown leaders, the police, and city hall officials. This notice constituted, in effect, a blacklist, for it stated openly the names of prominent secret society members and the location of their headquarters. It was attached to the door of the Chinese joss house, as well as on the doors of each secret society headquarters. Over the next two years, this initiative to disband the secret societies continued. ${ }^{49}$

To the dismay of the allies in the move, Chinese and white alike, highbinder violence again erupted in $1890 .{ }^{50}$ The mayor and elite Chinese merchants again mounted a campaign to suppress the secret societies. In a statement prepared for the Daily Oregonian in May of 1890, Mayor DeLashmutt declared, "when I suppressed them before I had no law to back me... The sentiment was so strong against the highbinders then that it would have been useless for them to resist." "51 With even greater intensity, whites and Chinese again collaborated. Prominent Chinese

${ }^{48}$ Morning Oregonian, Dec. 5, 1888, p. 8.

${ }^{49}$ In keeping with Chinese merchants' tendency exert their authority when collaborating with the white community, the merchants involved in this campaign did not agree to cooperate until fellow immigrant, Lee Bing Hung, who they claimed belonged to no highbinder society, was released from the city jail. And in usual fashion, the white authorities agreed and released Lee Bing Hung the following afternoon under the agreement that the Chinese mediators be responsible for him should he be accused of any crime.

${ }^{50}$ See, Ibid., Mar. 8, 1895; Ibid., Nov. 1, 1917.

${ }^{51}$ Ibid., May 9, 1890, p. 8. 
merchants such as Seid Back and Moy Ham eventually formed the Chinese Peace Society as a means to ending secret society violence. Eventually, the Chinese Peace Society formed into the Portland chapter of the Chinese Benevolent Association. ${ }^{52}$

\section{Conclusion}

This chapter has discussed, in broad terms, the organization, development, and roles of traditional Chinese associations in Portland. These associations and societies were organized along a framework similar to those in San Francisco and other Far Western cities and were based on models originally developed in China. Clan associations developed to support members that shared a common family name, while district associations formed their membership according to a common place of origin in China. Membership often overlapped between clan and district associations, as it did between them and secret societies, a third traditional association that thrived on illegal activities and sought to control members and non-members alike through protection money, tribute from gambling and prostitution houses, and the smuggling of immigrants, opium, and prostitutes. While all these associations in Portland were based on a model similar to those found in other cities, they were autonomous, localized Portland organizations.

Unique to Portland's Chinatown was the alliance between whites and elite Chinese merchants that formed to suppress the violence in the city's Chinatown.

${ }_{52}$ Despite the formation of the Chinese Peace Society and Chinese Benevolent Society, highbinder activity continued to occur into the 1940s, albeit to a lesser degree than was the case in the late nineteenth century. 
Through this collaboration Chinese merchants increased their status within both the white and Chinese communities and also developed new community institutions, such as the CCBA, that legitimated their authority as community and business leaders. Seid Back emerged as an especially prominent figure in Portland's Chinatown (even after he himself was convicted of smuggling opium and immigrants into the United States in the case of U.S. v. Wilson) and carried on extensive trans-Pacific business on his own and with white partners. Moy Ham, another mediator in the movement against Chinese secret society violence, eventually became the U.S. Consul for China for the Pacific Northwest. Collaboration across the racial divide, therefore, not only helped the Chinese and white communities better understand each other, but it also promoted the status and authority of a specific class of Chinese in Portland. It was this group of immigrants that laid the foundations for the second generation of Chinese Americans who led the community into the twentieth century. 
Chinese Exclusion ended in the midst of World War II, in 1942. With China as an ally in the fight against Japan, the United States Congress revoked the discriminatory legislation that, for sixty years, had attempted to deny entry to Chinese immigrants and, in turn, prohibited the rights of citizenship to those in the country. With the end of Exclusion, Chinese already in the United States were allowed to bring their long separated wives and families to their homes. But, even though anti-Chinese sentiment expressed in U.S. law had permeated the lives of first-generation Chinese immigrants, they had demanded due process rights in U.S. courts. Through their legal struggles, which numbered in the thousands in Multnomah County alone, Chinese gained more than a small measure of economic and cultural autonomy. In these cases, Chinese allied with one another for financial and testimonial support in court, drawing on traditional institutions they had adapted to fit the challenges posed by an unwelcoming American society and its legal system.

It would, however, be mistaken to assume that Chinese immigrants in Portland were a unified or homogenous group. Social distinctions based on class and levels of assimilation divided Chinese from one another, and these divisions affected the ways in which they interacted with one another and with the majority white population. Merchants, who began arriving in Portland in the 1850 s, quickly carved a niche for themselves in Portland's Chinatown. With prior knowledge of, and a willingness to adopt American models of business, these merchants, armed with English-language 
skills, gained a central place in the development of Chinatown and became a force in shaping white-Chinese relations. In the 1860 s and 1870 s Chinese merchants established clan and district associations and served as labor contractors for hundreds of newly arrived Chinese immigrants. In the courts, merchants provided financial and testimonial support for fellow immigrants in both civil and criminal cases. By aligning themselves along lines of clan and district associations, Chinese merchants demanded that their cases against whites and Chinese alike be heard in the U.S. legal system. With the advent of exclusion, merchant elites took advantage of loopholes in the enforcement of exclusion laws. Through collaboration with whites, Chinese merchants helped hundreds of immigrants enter the United States illegally and, at the same time, turned profits off the misfortune of these people. Through illicit trade in opium and immigrant smuggling, Chinese merchants established locally their power in Portland's Chinatown.

Laborers, on the other hand, did not gain the same control over their lives that Chinese merchants enjoyed. Sojourning laborers, instead, depended on the power of merchants. They relied on Chinatown merchants for jobs, financial assistance through the rotating-credit system, and representation, both financial and testimonial, in the U.S. courts. Their dependence on the merchant elite only increased in the 1880 s, when exclusion severely limited the ability for laborers to enter and find work in the United States. The division between laborers and merchants was evident from the earliest days of immigrant settlement in Portland. Merchants, with their knowledge of English and access to the courts, could demand payment from other Chinese and 
whites in business disputes. And in the 1880s and 1890s Chinese merchants, who had established themselves among the white community, served as translators in habeas corpus cases while Chinese laborers often sat idly in county jails awaiting trial and facing the prospect of deportation.

Divisions in Portland's Chinatown continued through the 1890s as Chinese merchants allied themselves with others who shared a common heritage in China and a common purpose in the United States. Many Chinese subscribed to secret societies that profited off of illicit trade in Chinese immigrants and prostitutes, and from the gambling and opium dens of Portland's Chinatown. On the other side, merchants, who had sometimes engaged in illegal trade themselves, increasingly joined with white leaders and officials to end the violence in Portland's Chinatown that first erupted in the late 1880 s. These Chinese merchants viewed collaboration with white authorities as a way of cementing their own status in Portland and gaining acceptance by the majority society. Similar to the experience of Chinese who assimilated to white religion and culture in the 1870 s and 1880 s, Chinese merchants, fighting against illicit trade, often met with deep-seated resentment from Chinese who survived economically through prostitution, gambling, and opium smuggling.

Although they remain understudied, county, district, and circuit court records illuminate key aspects of the first-generation Chinese immigrant experience in the United States. Civil cases demonstrate the ways in which Chinese worked with and among white businesses, the treatment of Chinese laborers working for white employers, and the daily run-ins of Chinese with white authorities as well as their 
fellow immigrants. Criminal cases display the violence and vice inside Portland's

Chinatown. The ways in which Chinese defended themselves against prosecution in court shows their ingenuity and their understanding of the U.S. legal system. The court cases also show that more often than is generally believed Chinese in court received treatment similar to their white counterparts.

If the records of local courts are not brought into the history of the first Chinese Americans, much will remain obscure, above all the daily workings of the Chinese immigrant enclave. And, in this case, we will miss the ways in which Chinese defiantly tackled discrimination and racism long before the concept of minority civil rights and protest took hold in the United States. 


\section{Primary Sources}

\section{Religious Documents}

Mattoon, Rev. C. H., Baptist Annals of Oregon, 1844 to 1900 (2 vols., McMinnville, Ore., 1905).

U.S. Presbyterian Church, U.S. Presbyterian Church in the U.S.A. Synods, Oregon Minutes...of the Sessions, 1st-16th, 1891-1906, (6 vols., Portland, Ore., 1890-1898).

\section{Court Cases}

\section{Circuit Court}

City of Portland v. Wong Kong, Multnomah County Circuit Court Records, Judgment \# 8549, Multnomah County Circuit Courthouse Files Room.

Twin Wo v. Ah Kim Dong business under the firm name Wing Fat, Multnomah County Circuit Court Records, Judgment \# 8905, Multnomah County Circuit Courthouse Files Room.

Chung You v. Wop Ching \& Co., Multnomah County Circuit Court Records, Judgment \# 7223, Multnomah County Circuit Courthouse Files Room.

City of Portland v. Wong Kong, Multnomah County Circuit Court Records, Judgment \# 9736, Multnomah County Circuit Courthouse Files Room.

Chin Toy v. Wong Jung, Multnomah County Circuit Court Records, Judgrnent \# 8906, Multnomah County Circuit Courthouse Files Room.

Low Wa Louis v. Application for Writ of Habeas Corpus, Multnomah County Circuit Court Records, Judgment \# 7649, Multnomah County Circuit Courthouse Files Room.

Chung Lung v. James Cooper, Multnomah County Circuit Court Records, Judgment \# 7614, Multnomah County Circuit Courthouse Files Room.

City of Portland v. Sung Fung, Multnomah County Circuit Court Records, Judgment \# 9066, Multnomah County Circuit Courthouse Files Room.

Gai Kee v. J.S. and C.C. Mullan, Multnomah County Circuit Court Records, Judgment \# 19697, Multnomah County Courthouse Files Room. 
Lam Ping v. Fung Sing, Multnomah County Circuit Court Records, Judgment \# 7217, Multnomah County Circuit Courthouse Files Room.

Loon Chung v. Wa Did, et al. Multnomah County Circuit Court Records, Judgment \# 7620, Multnomah County Circuit Courthouse Files Room.

Lee Chew v. Wing Hing Chewey, Multnomah County Circuit Court Records, Judgment \# 9038, Multnomah County Circuit Courthouse Files Room.

Lee Kwong v. Wong Ah Tong, Multnomah County Circuit Court Records, Judgment \# 10223, Multnomah County Circuit Courthouse Files Room.

Lee Seng v. Wong Ah Tong, Multnomah County Circuit Court Records, Judgment \# 10224, Multnomah County Circuit Courthouse Files Room.

Lee Hoone v. Thomas A. Jordon, Multnomah County Circuit Court Records, Judgment \# 12293, Multnomah County Circuit Courthouse Files Room.

Wong Dou Sai v. Wong Him Soon, Multnomah County Circuit Court Records, Judgment \# 11296, Multnomah County Circuit Courthouse Files Room.

Wong Doon v. Fing Lung and Co., Multnomah County Circuit Court Records, Judgment \# 12294, Multnomah County Circuit Courthouse Files Room.

King Liu v. Wong Sui Soon, Multnomah County Circuit Court Records, Judgment \# 11295, Multnomah County Circuit Courthouse Files Room.

Chung Yow (You) v. Hop Chung, et al, Multnomah County Circuit Court Records, Judgment \# 10546, Multnomah County Circuit Courthouse Files Room.

Hop Chung, et al. v. Chung You, Multnomah County Circuit Court Records, Judgment \# 10547, Multnomah County Circuit Courthouse Files Room.

Kwong Wah Lung \& Co. v. King Tai \& Co., Multnomah County Circuit Court Records, Judgment \# 10555, Multnomah County Circuit Courthouse Files Room.

Wing Sung \& Co. v. Lung Yik Co., Multnomah County Circuit Court Records, Judgment \# 10111 1//2, Multnomah County Circuit Courthouse Files Room.

Wing Sung \& Co v. Judgement retired, Multnomah County Circuit Court Records, Judgment \# 10012, Multnomah County Circuit Courthouse Files Room.

A.P. DeLin \& Co. v. Gee Wa \& Co., Multnomah County Circuit Court Records, Judgment \# 10022, Multnomah County Circuit Courthouse Files Room. 
Ye ARk \& Co. v. Gee Wa Co., Multnomah County Circuit Court Records, Judgment \# 10024, Multnomah County Circuit Courthouse Files Room.

L.E. Thompson v. Sui Lee \& Ching Yuen Co., Multnomah County Circuit Court Records, Judgment \# 10055, Multnomah County Circuit Courthouse Files Room.

Ting Gong and Fong Fum v. Sui Lee and Ying Lung and Dong Long, Multnomah County Circuit Court Records, Judgment \# 10058, Multnomah County Circuit Courthouse Files Room.

Gim Fook v. Sam Lee, Multnomah County Circuit Court Records, Judgment \# 10059, Multnomah County Circuit Courthouse Files Room.

Chin Chun Ban v. Yuen Chong \& Co., Multnomah County Circuit Court Records, Judgment \# 10096, Multnomah County Circuit Courthouse Files Room.

Hop Chong \& Co. v. Todd \& Biven, Multnomah County Circuit Court Records, Judgment \# 9192, Multnomah County Circuit Courthouse Files Room.

Louis Fong Bo assigner of Duck Chung Ming \& Co. v. J.A. Jordan, Multnomah County Circuit Court Records, Judgment \# 10600, Multnomah County Circuit Courthouse Files Room.

Hop Chong \& Co. v. J.A. Jordon, Multnomah County Circuit Court Records, Judgment \# 10601, Multnomah County Circuit Courthouse Files Room.

Kwong Loon Kee \& Co. v. C.M.S. Sprague Co., Multnomah County Circuit Court Records, Judgment \# 7736, Multnomah County Circuit Courthouse Files Room.

Kwong Loon Kee \& Co. v. C.M.S. Sprague \& Co., Multnomah County Circuit Court Records, Judgment \# 7737, Multnomah County Circuit Courthouse Files Room.

Chung Yuen v. Kit Lee, Grant County Circuit Court Records, Judgement \# 1110 , Oregon State Archives.

State of Oregon v. John Kee, Multnomah County Circuit Court Records, Judgment \# 10209, Multnomah County Circuit Courthouse Files Room.

State of Oregon v. Ah You,Multnomah County Circuit Court Records, Judgment \# 10212, Multnomah County Circuit Courthouse Files Room.

State of Oregon v. Amy Brinton, Multnomah County Circuit Court Records, Judgment \# 10213, Multnomah County Circuit Courthouse Files Room. 
State of Oregon v. Lang Ah Sing, Multnomah County Circuit Court Records, Judgment \# 10214, Multnomah County Circuit Courthouse Files Room.

State v. Lee Ping Bow, 10 Oregon Reports (1881), 27-30.

State of Oregon v. Moy Youk, Multnomah County Circuit Court Records, Judgment \# 10213, Multnomah County Circuit Courthouse Files Room.

State of Oregon v. Lee Moy, Multnomah County Circuit Court Records, Judgment \# 10216, Multnomah County Circuit Courthouse Files Room.

State of Oregon v. Ah Ming, Multnomah County Circuit Court Records, Judgment \# 9981, Multnomah County Circuit Courthouse Files Room.

State of Oregon v. China Joe, Multnomah County Circuit Court Records, Judgment \# 6654, Multnomah County Circuit Courthouse Files Room.

State of Oregon v. Ah Quong, Multnomah County Circuit Court Records, Judgment \#7061, Multnomah County Circuit Courthouse Files Room.

State of Oregon v. Yee Chung Chik, Multnomah County Circuit Court Records, Judgment \# 9976, Multnomah County Circuit Courthouse Files Room.

State of Oregon v. Ah Jim, Multnomah County Circuit Court Records, Judgment \# 9974, Multnomah County Circuit Courthouse Files Room.

State of Oregon v. Ah Lung, Multnomah County Circuit Court Records, Judgment \# 11099, Multnomah County Circuit Courthouse Files Room.

State of Oregon v. Sing Fook, Multnomah County Circuit Court Records, Judgment \# 11101, Multnomah County Circuit Courthouse Files Room.

State of Oregon v. Wie Ying, Multnomah County Circuit Court Records, Judgment \# 11108, Multnomah County Circuit Courthouse Files Room.

State of Oregon v. Wa Luey, Multnomah County Circuit Court Records, Judgment \# 11560 1/2, Multnomah County Circuit Courthouse Files Room.

\section{Probate Court}

Ah Jack, Multnomah County Probate Court, Guar. Est. \#702, 5 Nov. 1857, Multnomah County Courthouse Files Room. 
Bo Ah Fat, Multnomah County Probate Court, Est. \# 1068, 4 June 1884, Multnomah County Courthouse Files Room.

Chan Lon Heung, Multnomah County Probate Court, Est. \#927, 6 May 1883, Multnomah County Courthouse Files Room.

Chee Gim Sing, Multnomah County Probate Court, Est. \#1972, 3 Jan. 1884, Multnomah County Courthouse Files Room.

Cheun Bok Quan, Multnomah County Probate Court, Est. \#1126, 22 Jan. 1885, Multnomah County Courthouse Files Room.

Chin You, Multnomah County Probate Court, Guar. \#2333, 4 Aug. 1892, Multnomah County Courthouse Files Room.

Chou Chu, Multnomah County Probate Court, Est. \#1080, 21 Aug. 1894, Multnomah County Courthouse Files Room.

Chow Chou Chong, Multnomah County Probate Court, Est. \#1127, 28 Dec. 1884, Multnomah County Courthouse Files Room.

Chow Quay, Multnomah County Probate Court, Est. \#5310, 11 July 1904, Multnomah County Courthouse Files Room.

Chun Bock, Multnomah County Probate Court, Est. \#1605, 4 Feb. 1889, Multnomah County Courthouse Files Room.

Chung Mow, Multnomah County Probate Court, Est. \#3859, 12 Oct. 1899, Multnomah County Courthouse Files Room.

Fong Don Hong, Multnomah County Probate Court, Est. \#4231, 26 Sept. 1884, Multnomah County Courthouse Files Room.

Ki Tom, Multnomah County Probate Court, Est. \#2949, 3 March 1896, Multnomah County Courthouse Files Room.

Kim Ching Hoy, Multnomah County Probate Court, Est. \#1069, 4 June 1884, Multnomah County Courthouse Files Room.

Kim Kim Been, Multnomah County Probate Court, Est. \#1065, 25 Sept. 1884, Multnomah County Courthouse Files Room.

Lee Ah Toy, Multnomah County Probate Court, Est. \#1070, 5 June 1884, Multnomah County Courthouse Files Room. 
Lee Fook, Multnomah County Probate Court, Est. \#1066, 2 June 1884, Multnomah County Courthouse Files Room.

Lin Hong Kim, Multnomah County Probate Court, Est. \#1076, 4 June 1884, Multnomah County Courthouse Files Room.

Low Chin, Multnomah County Probate Court, Est. \#1606, 19 Feb. 1889, Multnomah County Courthouse Files Room.

Suie Yan, Multnomah County Probate Court, Guar. \# 2331, 4 Oct. 1892, Multnomah County Courthouse Files Room.

Sue Parrot King, Multnomah County Probate Court, Est. \#12270 and 12293, 13 April 1913, Multnomah County Courthouse Files Room.

Way Sing, Multnomah County Probate Couri, Est. \# 1125, 3 Jan. 1885, Multnomah County Courthouse Files Room.

Wong Ah Dow, Multnomah County Probate Court, Est. \#1073, 4 June 1884, Multnomah County Courthouse Files Room.

Wong Ah Hon, Multnomah County Probate Court, Est. \#1075, 4 June 1884, Multnomah County Courthouse Files Room.

Wong Loy Hing, Multnomah County Probate Court, Est. \# 1067, 2 June 1884, Multnomah County Courthouse Files Room.

Wong Sing Wiing, Multnomah County Probate Court, Est. \#1074, 4 June 1884, Multnomah County Courthouse Files Room.

\section{Newspapers}

Daily Oregonian

Morning Oregonian

Oregonian

Grant County News

The West Shore 


\section{Secondary Sources}

Armentrout Ma, L. Eve, "Chinatown Organizations and the Anti-Chinese Movement, 1882-1914," in Sucheng Chan, ed., Entry Denied: Exclusion and the Chinese

Community in America, 1882-1943 (Philadelphia: Temple University Press, 1991), 147-169.

Aubitz, Shawn, "Tracing Chinese Immigration into the United States: The Use of Federal Documents-The Case of Moy Ni Kee," Ethnic Forum: Bulletin of Ethnic Studies and Ethnic Bibliography, 2 (1987), 64-75.

Barlow, Jeffrey, and Christine Richardson, China Doctor of John Day (Portland, Ore.: Binford \& Mort, 1979).

Barth, Gunther, Bitter Strength: A History of the Chinese in the United States, 18501870 (Cambridge, Mass.: Harvard Universiiy Press, 1964).

Bodnar, John, "Immigration Portrayed as an Experience of Transplantation," in Jon Gjerde, ed., Major Problems in American Immigration \& Ethnic History (Boston: Houghton Mifflin Company, 1998), 8-16.

Bolles, Joshua, "Historical Sketches of the Missions among the North American Foreign Missions of the Presbyterian Church," (Philadelphia, Penn.: Presbyterian Church of the United States of America, 1891).

Butler, Anne M., Daughters of Joy, Sisters of Misery: Prostitutes in the American West, 1865-90 (Champaign: University of Illinois Press, 1985).

Chan, Sucheng, ed., Entry Denied: Exclusion and the Chinese Community in America, 1882-1943 (Philadelphia: Temple University Press, 1991).

----This Bittersweet Soil: The Chinese in California Agriculture, 1860-1910 (Berkeley: University of California Press, 1986).

Chen, Yong. "The Internal Origins of Chinese Emigration to California Reconsidered," Western Historical Quarterly, 28 (Winter 1997), 521-546.

---- Chinese San Francisco, 1850-1943 (Stanford: Stanford University Press, 2000).

Chia-Chi Ho, Nelson, "Portland's Chinatown: The History of an Urban Ethnic District," (Portland, Ore.: Bureau of Planning, City of Portland, Oregon, 1978). 
Cloud, Patricia and David Galenson, "Chinese Immigration and Contract Labor in the Late Nineteenth Century,” Explorations in Economic History, 24 (1987), 22-42.

---- "Chinese Immigration: Reply to Charles McClain," Explorations in Economic History, 28 (1991), 239-247.

Conzen, Kathleen Neils, "The Invention of Ethnicity: A Perspective from the USA," in Jon Gjerde, ed., Major Problems in American Immigration \& Ethnic History (Boston: Houghton Mifflin Company, 1989), 22-31.

Corbett, P. Scott and Nancy Parker Corbett, "The Chinese in Oregon, c. 1870-1880," Oregon Historical Quarterly, 78 (1977), 73-85.

Dirlik, Arlif, ed., Chinese on the American Frontier (Lanham, Mass.: Rowman \& Littlefield Publishers, Inc., 2001).

Fairbank, John K., ed., The Missionary Enierprise in China and America (Cambridge, Mass.: Harvard University Press, 1974).

Glazer, Nathan and Daniel P. Moynihan, Ethnicity: Theory and Experience (Cambridge, Mass.: Harvard University Press, 1975).

Goodman, Brynna, Native Place, City, and Nation: Regional Networks and Identities in Shanghai, 1853-1937 (Berkeley, University of California Press, 1995).

Goldman, Marion S., Gold Diggers \& Silver Miners: Prostitution and Social Life on the Comstock Lode (Ann Arbor, Mich.: University of Michigan Press, 1981).

Grant Tucker, Cynthia, Prophetic Sisterhood: Liberal Women Ministers of the Frontier, 1880-1930 (Boston: Beacon Press, 1990).

Handlin, Oscar, The Uprooted: The Epic Story of the Great Migrations That Made the American People, Revised Edition (Philadelphia: University of Pennsylvania Press, 2002).

Hietter, Paul T., "A Surprising Amount of Justice: The Experience of Mexican and Racial Minority Defendants Charged with Serious Crimes in Arizona, 1865-1920." Pacific Historical Review, 70 (August 2001), 183-219.

Higham, John, Send These to Me: Immigrants in Urban America (Baltimore: The Johns Hopkins University Press, 1984). 
---- "Integrating America: The Problem of Assimilation in the Nineteenth Century," in Jon Gjerde, ed., Major Problems in American Immigration \& Ethnic History (Boston: Houghton Mifflin Company, 1989), 16-22.

Kim, Hung-chan and Richard W. Markov, "The Chinese Exclusion Laws and Smuggling Chinese into Whatcom County, Washington, 1890-1900," Annals of the Chinese Historical Society of the Pacific Northwest (1983), 16-30.

Lee, Douglas, "Sacred Cows and Paper Tigers: Politics in Chinese America, 18801900," Annals of the Chinese Historical Society, 32 (1989), 86-103.

Lee, Erika, "Enforcing the Borders: Chinese Exclusion along the U.S. Borders with Canada and Mexico, 1882-1924," Journal of American History (2002), 54-86.

Light, Ivan, "From Vice District to Tourist Attraction: The Moral Career of American Chinatowns, 1880-1940," Pacific Historical Review, 43 (1974), 367-394.

Lydon, Sandy, Chinese Gold: The Chinese in the Monterey Bay Region (Capitola, Calif.: Capitola Book Company, 1985).

Lyman, Stanford M., The Asian in North America, (Santa Barbara, Calif.: ABC-Clio, 1977).

MacColl, E. Kimbark. The Shaping of a City: Business and Politics in Portland, Oregon 1885 to 1915. (Portland, Ore.: The Georgian Press Company, 1976).

McClain, Charles J.. In Search of Equality: The Chinese Struggle Against Discrimination in Nineteenth-Century America. (Berkeley: University of California Press, 1994).

-.-- "Chinese Immigration: A Comment on Cloud and Galenson," Explorations in Economic History, 27 (1990), 363-378.

Miller, Stuart Creighton, The Unwelcome Immigrant: The American Image of the Chinese, 1785-1882. (Berkeley: University of California Press, 1969).

Myers, Gloria E., A Municipal Mother: Portland's Lola Greene Baldwin, America's First Policewoman (Corvallis, Ore.: Oregon State University Press, 1995).

Ong Hing, Bill, Making and Remaking Asian America through Immigration Policy, 1850-1990 (Stanford: Stanford University Press, 1993).

Pascoe, Peggy, Relations of Rescue: The Search for Female Moral Authority in the American West, 1874-1939 (New York: Oxford University Press, 1990). 
Peffer, George Anthony, "Forbidden Families: Emigration Experiences of Chinese Women Under the Page Law, 1875-1882,"Journal of American Ethnic History (1983), 28-46.

Rodgers, Daniel T., The Work Ethic in Industrial America, 1850-1920 (Chicago: University of Chicago Press, 1978).

Salyer, Lucy E., Laws Harsh as Tigers: Chinese Immigrants and the Shaping of Modern Immigration Law (Chapel Hill: University of North Carolina Press, 1995).

Salyer, Lucy E., ed., Entry Denied: Exclusion and the Chinese Community in America, 1882-1943 (Philadelphia: Temple University Press, 1991).

Saxton, Alexander, The Indispensable Enemy: The Labor and the Anti-Chinese Movement in California (Berkeley: University of California Press, 1971).

Shumsky, Neil Larry, “Americans and Segregated Prostitution," Journal of Social History (1986), 665-679.

Shumsky, Neil Larry and Larry M. Springer, "San Francisco's Zone of Prostitution, 1880-1934, Journal of Historical Geography, 7 (1981), 71-89.

Spence, Jonathan D., The Search for Modern China (New York: W.W. Norton \& Company, 1990).

Stanley, Timothy J., "Schooling, White Supremacy, and the Formation of a Chinese Merchant Public in British Columbia," BC Studies, 107 (1997), 3-28.

Strong, Linda Kay, "Mutual Support Organizations of Northwest Chinatowns," Pacific Northwest Forum, 6 (1992), 29-37.

Sui, Paul C.P., "The Chinese Laundryman as a Sojourner," in John Kuo Wei, ed., The Chinese Laundryman: A Study of Social Isolation (New York: New York University Press, 1987), 294-301.

Takagi, Paul and Tony Platt, "Behind the Gilded Ghetto: An Analysis of Race, Class and Crime in Chinatown," Crime and Social Justice (1978), 2-23.

Takaki, Ronald, Iron Cages: Race and Culture in 19th-Century America, Revised Edition (New York: Oxford University Press, 2000).

----Journey to Gold Mountain: The Chinese in 19th-Century America (Philadelphia: Chelsea House Publishers, 1989). 
---- Strangers from a Different Shore: A History of Asian Americans (New York: Chelsea House Publications, 1987).

Tracy, Charles A., "Race, Crime and Social Policy: The Chinese in Oregon, 18711885," Crime and Social Justice (1980), 11-25.

Shih San, Henry Tsai, The Chinese Experience in America (Bloomington, Ind: University of Indiana Press, 1984).

---- China and the Overseas Chinese in the United States, 1868-1911 (Fayetteville, Ark.: University of Arkansas Press, 1983).

Wang, Xinyang, Surviving the City: The Chinese Immigrants Experience in New York City, 1890-1970 (Lanham, Mass.: Rowman \& Littlefield Publishers, 2001).

Wong, K. Scott, "Liang Qichao and the Chinese of America: A Re-evaluation of his Selected Memoir of Travels in the New World." Journal of American Ethnic History, 11 (Summer 1992), 3-24.

Wong, K. Scott, and Sucheng Chan, eds., Claiming America: Constructing Chinese American Identities During the Exclusion Era. (Philadelphia: Temple University Press, 1998).

Woo, Wesley, "Chinese Protestants in the San Francisco Bay Area," in Sucheng Chan, Entry Denied: Exclusion and the Chinese Community in America, 1882-1943 (Philadelphia: Temple University Press, 1991), 145-213.

Wu, Chen Tzu, ed., Chink! A Documentary History of Anti-Chinese Prejudice in America (New York: Oxford University Press, 1972).

Wunder, John R., "Law and the Chinese on the Southwest Frontier, 1850s-1902." Western Legal History, 2 (1989): 139-158.

---- "Chinese in Trouble: Criminal Law and Race on the Trans-Mississippi West Frontier." Western Historical Quarterly, 17 (1986), 25-41.

---- "The Courts and the Chinese in Frontier Idaho." Idaho History, 25 (1981): 21-32.

Yung, Judy, Unbound Feet: A Social History of Chinese Women in San Francisco (Berkeley: University of California Press, 1995).

-.--Unbound Voices: A Documentary History of Chinese Women in San Francisco (Berkeley, University of California Press, 1999). 
Yung-Deh, Richard Chu, "Chinese Secret Societies in America: A Historical Survey," Asian Profile, 1 (1973), 21-38.

Xinyang Wang, Surviving the City: The Chinese Immigrant Experience in New York City, 1890-1970 (Lanham, Mass.: Rowman \& Littlefield Publishers, 2001).

Zhao, Xiaojian, Remaking Chinese America: Immigration, Family, and Community, 1940-1965 (New Brunswick, N.J.: Rutgers University Press, 2002.

Masters theses, dissertations, and unpublished lectures

Armentrout-Ma, L. Eve, "Chinese Politics in the Western Hemisphere, 1893-1911:

Rivalry Between Reformers and Revolutionaries in the Americas," Ph.D. diss., University of California, Davis, 1977.

Chiu, Herman B., "Oregon's Chinese and Newspaper Coverage: The Road to Acceptance." M.A. thesis, University of Oregon, 1995.

Griffith, Sarah M., "Ethnicity, Solidarity, and Tradition: A Study into the Dynamics and Complexities of the Chinese Immigrant Community in John Day, Oregon, 18601906" (Undergrad. Honors Thesis, Lewis \& Clark College, 2000).

Lyon, Cherstin M., "Chinese Immigration, Cultural Hegemony, and the Politics of Everyday Crime in Portland, Oregon, 1859-1908." Masters thesis, University of Oregon, 1998.

Liestman, Daniel, "'To Labor for the Conversion of the Heathen Who Came in Our Midst:' Protestants and the Chinese in Nineteenth Century America," Winifred E. Weter Faculty Award Lecture, Seattle Pacific University, April 14, 1994.

Laythe, Joseph Willard, "Bandits and Badges: Crime and Punishment in Oregon, 1875-1915.” Ph.D. diss., University of Oregon, 1996.

McConnell, Gregory Clark, "An Historical Geography of the Chinese in Oregon." M.A. thesis, University of Oregon, 1979.

Moyer, Elgin S, “China at Our Door.” Ph.D. diss., University of Chicago, 1938. 